TATIANA BENEVIDES MAGALHÃES BRAGA

\title{
PRÁTICAS PSICOLÓGICAS EM INSTITUIÇÕES E FORMAÇÃO EM PSICOLOGIA: POSSIBILIDADES DE REFLEXÕES SOBRE O SENTIDO DA PRÁTICA
}

Dissertação apresentada ao Instituto de Psicologia da Universidade de São Paulo como exigência parcial para a obtenção do título de Mestre em Psicologia.

\section{SÃo PaUlo}




\title{
PRÁTICAS PSICOLÓGICAS EM INSTITUIÇÕES E FORMAÇÃO EM PSICOLOGIA: POSSIBILIDADES DE REFLEXÕES SOBRE O SENTIDO DA PRÁTICA
}

Dissertação apresentada ao Instituto de Psicologia da Universidade de São Paulo como exigência parcial para a obtenção do título de Mestre em Psicologia.

Área de concentração: Psicologia Escolar e do Desenvolvimento Humano

Orientador: Professora Doutora Eda Marconi Custódio

\author{
SÃo PAUlo
}

2005 


\section{Ficha Catalográfica preparada pelo Serviço de Biblioteca}

e Documentação do Instituto de Psicologia da USP

Braga, T. B. M.

Práticas psicológicas em instituições e formação em psicologia: possibilidades de reflexões sobre o sentido da prática./ Tatiana Benevides Magalhães Braga. - São Paulo: s.n., 2005. - 179p.

Dissertação (mestrado) - Instituto de Psicologia da Universidade de São Paulo. Departamento de Psicologia da Aprendizagem, do Desenvolvimento e da Personalidade.

Orientadora: Eda Marconi Custódio.

1. Fenomenologia 2. Atendimento psicológico 3. Supervisão clinica I. Título. 


\section{PRÁTICAS PSICOLÓGICAS EM INSTITUIÇÕES E FORMAÇÃO EM PSICOLOGIA: POSSIBILIDADES DE REFLEXÕES SOBRE O SENTIDO DA PRÁTICA}

TATIANA BENEVIDES MAGALHÃES BRAGA

BANCA EXAMINADORA

Eda Marconi Custódio

Henriette Tognetti Penha Morato

Heloísa Szymanski

Dissertação defendida e aprovada em 


\section{Encontros e desencontros}

Toda viagem

É uma viagem

Para dentro

De si mesmo.

Todo encontro

É um encontro

Também consigo,

Com as possibilidades

Que eu mesmo podia ter sido.

Ao encontrar-me

Com outros - coisas, pessoas, lugares

Parte do outro dele se sai

Fica no ar, fica comigo,

E parte de mim daqui se vai

Para o outro, pelos ares.

(Tatiana Benevides Magalhães

Braga, 10/2003) 


\section{Agradecimentos}

À família e aos amigos, pelo constante apoio, diálogo, carinho e troca, sem o qual este trabalho teria sido impossível.

À minha orientadora, Professora Doutora Eda Marconi Custódio, pelo acompanhamento paciente de meu percurso.

Aos membros da banca examinadora Henriette Tognetti Penha Morato, pelas constantes reflexões e releituras, e Heloísa Szymanski, pela leitura cuidadosa e sugestões oportunas.

A todos os colaboradores do Laboratório de Estudos e Prática em Psicologia Fenomenológica e Existencial, pela possibilidade de, a cada encontro, refletir e enriquecer tanto minha prática profissional quanto este trabalho, em especial àqueles que dele participaram.

Às instituições, clientes e alunos, com quem muito aprendi e a quem dedico esta pesquisa. 


\section{Sumário:}

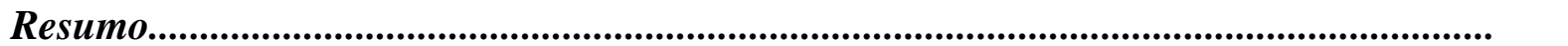

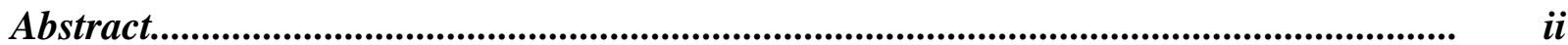

1. Antiga morada: sentidos que sentia, inquietações que eles implicavam, recursos que tinha para construir um sentido para sentidos e inquietações

2. Preparativos de viagem: trazendo à presença a questão do ensino de Psicologia Clínica.

2.1 A questão do conhecimento: origem e genealogia de uma perspectiva.

2.2 Nascimento das ciências e desenvolvimento das ciências humanas: críticas a essa perspectiva.

2.3 Psicologia: genealogia de uma ciência.

3. Práticas Educativas.

3.1 A construção histórica de uma pedagogia libertadora no Brasil: avanços e percalços das idéias educacionais.

3.2 Ensino de Psicologia

3.3 Psicologia e ensino de Psicologia: algumas considerações sobre o contexto brasileiro.

4. Psicologia clínica e experiência: em busca de pesquisa-prática-aprendizagem contextualizadas.

4.1. Atenção Psicológica em Instituições e Plantão Psicológico: um caminho caminhando em direção a outras perspectivas.

5. Meio de transporte: relatos de experiência sentindo sentidos e significando o sentido da viagem.

5.1 O espaço no qual se dá a viagem: instrumentos para compreender - abarcar e entender - dando luz e sombra. 
6. Diário de bordo: Relatos de experiência construindo questões e significando o sentido da mudança......................................................................................................................... p...

7. Análise: construindo uma compreensão de sentido possível.............................................. p.106

8. Considerações Possíveis................................................................................................... p.153

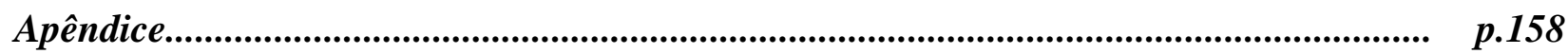

Referências............................................................................................................. p.173

Bibliografia............................................................................................................... p.179 


\section{RESUMO:}

Esta pesquisa visa estudar, em uma perspectiva fenomenológica existencial, como as práticas psicológicas em instituições disponibilizam, para alunos estagiários nestas práticas, a apreensão e a compreensão de modos de ação profissional, que se reconfiguram a partir da solicitação dada pelo contexto. Os modos de reflexão e construção do fazer clínico são investigados no âmbito destas práticas, buscando reconstituir o percurso de aprendizagem dos alunos. Para tanto, recorre-se a narrativas, segundo BENJAMIN, de alunos do curso de Psicologia de uma mesma Universidade, participantes de uma modalidade de práticas clínicas em instituições, o Plantão Psicológico, em projetos de extensão universitária. As narrativas em torno da experiência de aprendizagem da ação clínica através da prática foram colhidas por meio de depoimentos coletados a partir de uma pergunta disparadora e registrados através do uso de gravador. Depois de transcritos, trechos dos depoimentos foram esclarecidos juntos aos participantes da pesquisa, e as respostas foram incorporadas aos depoimentos. Os depoimentos foram literalizados e devolvidos aos sujeitos para sua avaliação, vericizando-os. A análise dos depoimentos foi realizada conforme a proposta de CRITELLI, norteando-se pela realização de um diálogo com um dos depoimentos em particular. Busca-se o sentido dos relatos e apresenta a crise e o desalojamento como lócus privilegiado para a desconstrução de conceitos préformados, resgatando a esfera da afetabilidade como condição da abertura de possibilidades para o encontro clínico. O resgate da própria percepção para a tecitura de um espaço intersubjetivo vai sendo construído a partir do seu questionamento nos espaços pedagógicos de diálogo, particularmente na supervisão, e permite reconfigurar a reflexão teórica partindo-se da experiência. Este questionamento permite também a reconfiguração experiencial do encontro clínico como lugar de questionamento visando o resgate de sentido, a partir das possibilidades de compreensão abertas pela afetabilidade. Os depoimentos apontam para a necessidade de uma horizontalidade que favoreça a dialogia entre teoria e prática como forma de melhor possibilitar uma aprendizagem auto-apropriada.

Palavras chave: Fenomenologia, Plantão Psicológico, Supervisão de Plantão, Formação Profissional. 


\section{Abstract}

This research intends to study, in an existential phenomenological perspective, the way by the psychological practices in institutions turn available the professional actions modes comprehension, and his departing context transformations, by the students of this practices. The forms of reflection and clinical practice construction are investigated in this practices circuit, looking for the student's learn trajectory reconstruction. For this intend it use the narratives (BENJAMIN, 1980) of the same University Psychology's students, that participate in a clinical practice mode, the Psychological Attendance. The narratives about the learn experience of clinical action trough the practice were collected by testimonials, made departing of a shooting question and recorded. After the transcription, parts of the testimonial were confirmed against the subjects' research and the answers were incorporated in the testimonials. The testimonials were turned literally and returned to the subjects for their evaluation and confirmation. The testimonial's analysis were made according CRITELLI (1996), directing by the making of a dialogue with the testimonials, looking for the report's sense. This investigation presents the crisis and the dislodgesness like a privileged place to the deconstruction of pre-made concepts, ransoming the affectable sphere like a possibilities opening condiction to the clinical encounter. The ransom of self-perception like an instrument to the inter-subjective area's weaveness are going to be constructed, departing of this self-perception asking in the dialogues places, particularity in the supervision. This movement turns possible the theorical reflection reconfiguration, departing of the experience. This asking trajectory permits, too, the experiential reconfiguration of clinical encounter like a questionarity place, aiming at the sense ransom, departing of the comprehension possibilities opened by the affectability. The testimonials points to the relevance of a $n$ horizontality that privilege the dialogy between theory and practice, implementing the possibilities of an self-appropriated learning.

Key Words: Phenomenology, Psychological Attendance, Psychological Attendance Supervision, Psychological Professional Formation. 


\title{
1. Antiga morada: sentidos que sentia, inquietações que eles implicavam, recursos que tinha para construir um sentido para sentidos e inquietações
}

\author{
“O problema não é inventar. \\ É ser inventado a cada instante \\ E nunca ficar pronta \\ Nossa versão convincente."
} (Carlos Drumonnd de Andrade,1984)

Esta é uma história de entrelaçamentos de pessoas, olhares, sentimentos, significados, compreensões, sentidos. Apresentá-la significa trazer à tona as práticas, as vivências, o pensar e o sentir de pessoas, grupos e instituições. É contar a história de muitos alunos que, desde o ensino primário, aprenderam a compreender o mundo através de conceitos e idéias relativamente bem “encaixados” e, ao chegar no curso de Psicologia, encontram, como não poderia deixar de ser, um currículo disperso, cursando disciplinas que partem de diferentes conceitos e idéias, pouco articuladas entre si. É contar a história de alunos perdidos entre teorias que, ao chegar na prática, sentem-se na “obrigação” de “encaixar” conceitos. Alunos que sentem ressoar em si algo de seus clientes, mas que são, muitas vezes, pouco ouvidos, ou vêem este “algo" pouco referendado, ao longo do curso, no vazio dos corredores institucionais, alguns superlotados do burburinho de alunos e professores.

Alunos que, então, “são escolhidos” pelas teorias, áreas e sistemas. Mas que vez ou outra têm a chance de experimentar, de criar, de fazer algo que (também) parta de si próprios: que pela experiência percebem que sempre irão reler a si mesmos, às teorias, à Psicologia, como ciência e profissão, ao humano. Da mesma forma que, muitas vezes, em sua experiência de existir, fora - e dentro - das instituições de ensino, haviam relido a (sua) realidade. Desta história, compartilhada em conversas de corredor, em discussões de sala de aula, em relatos de atendimentos - na supervisão e fora dela - , relatada em trabalhos de faculdade, em jornais de 
centro acadêmico, em relatos de experiência de congressos, revelada às vezes por “surpresas” trazidas pelos clientes - pessoas, grupos e instituições - também compartilhei.

Trilhá-la foi tomar o árduo caminho do reconhecimento de que não existiriam verdades absolutas, de que eu nunca estaria "pronta” como psicóloga, assim como nunca estarei pronta como pessoa. Implicou compreender que o ensaio já é a apresentação e que defrontar-me com o outro no fazer clínico é também deparar-me com o fato de que nós, como humanos, sempre estaremos incompletos. Nunca teremos respostas para tudo, sempre seremos estranhos a nós mesmos, ambíguos, e apenas conseguiremos olhar uma perspectiva entre as possibilidades do real - estamos, enfim, mundanizados.

A origem deste estudo, nesse sentido, remonta a meus questionamentos e experiências na formação em Psicologia. Ao longo dos primeiros anos do curso de Psicologia da Universidade de São Paulo, tive contato com diversas abordagens psicológicas, através de aulas expositivas que se orientavam pela exposição de teorias e por exemplificações de casos clínicos interpretados à luz dessas teorias. Porém, as teorias pareciam muito distantes da vivência da maioria dos alunos, e parecia haver uma ilusão de que, pelo fato de todos ainda estarem engatinhando - motivo pelo qual não dominavam ainda não apenas a teoria, mas também a técnica a ela subjacente - não eram, por isso, capazes de executar práticas em seu âmbito. Desta situação brotaram questionamentos que, relacionados inicialmente com o conhecimento das teorias e práticas psicológicas, foram se encaminhando à experiência de um aluno de graduação em Psicologia e suas possibilidades de compreensão acerca de seu fazer. Como reconhecer-nos, na mesma esfera do humano, na concepção de homem de Freud, Melanie Klein ou Skinner? Haveria um “mais além” para a compreensão de teorias e autores, que ainda não possuíamos? Haveríamos de compreender melhor na situação de atendimento? Mas como poder recorrer a uma forma de compreender o outro sem que ela nada diga a 
respeito de mim mesmo, que não faz sentido para mim? São as releituras de outros autores que me possibilitarão isso? Mas, então, onde estariam estes “outros”? Existe alguma coerência entre o que vivo no meu cotidiano e as diversas Psicologias, uma forma de compreender que, se não é a priori, possa ocorrer na esfera histórica, ética, política, ou em outra esfera à qual não estou olhando?

Foi a partir das práticas curriculares de atendimento do quarto ano em diante que algumas vivências se configuraram para mim. Em algumas disciplinas, sua estruturação e seus objetivos voltavam-se ao ensino técnico, algumas vezes inclusive dizendo-se diretamente aos alunos o que deveria ser dito ou feito nos atendimentos, instaurando-se uma rigidez na qual não havia interjogo com a experiência pessoal. Mais tarde, em outras aulas, cuja proposta era possibilitar a fala dos alunos, produzia-se muitas vezes uma nova rigidez: a da “espontaneidade como teoria” que, na prática, redundava em método padronizado, restando ao aluno a crença de que tudo a fazer era "tão somente (...) fazer o que se pode e ir só, com as próprias pernas...” (MORATO \& SCHIMIDT, 1999 p.123).

Sentia, então, não apenas em mim, mas em outros alunos, nos encontros do cotidiano acadêmico uma angústia ambígua, entre distância e proximidade com o cliente, ampliada para o âmbito da identidade. Quem sou eu, como psicóloga? Como alguns me pedem para apenas perguntar ao cliente e interpretá-lo, outros me dizem “seja você” e outros ainda para que eu simplesmente compreenda? Como posso ser eu mesma “simplesmente compreendendo”? Como posso "apenas interpretar” se não estou segura do que interpreto? O atendimento nunca segue exatamente as discussões de supervisão... Estou sendo coerente, ou “enganando” - ainda que sem intenção - o supervisor? Ou o cliente? Ou a mim mesma?

Todas essas vivências, porém, apresentavam um ponto de convergência: a busca, na formação, parecia muito mais dirigida a uma aproximação em relação à técnica do que ao 
desenvolvimento de um olhar para aquele que sofre, aquele de quem parte a demanda por auxílio psicológico. Lembro-me do nervosismo que senti antes de meu primeiro atendimento, com uma criança e a mãe. Uma colega então me disse: “Faça o seguinte: pergunte 'O que trouxe vocês aqui?’ Aí você vai ver que vai vir tudo... Depois na semana seguinte pergunte: ‘Então? Como foi essa semana?’ Aí vai vir tudo de novo...” Isto porque, antes mesmo de atender, a primeira preocupação como estagiária era para o que eu ia dizer a um cliente que ainda nem mesmo conhecia. Da mesma forma, era como ele me fora apresentado em supervisão: ouvi, antes do atendimento, um relato e uma supervisão do “caso” a ser atendido... Percebo como eu mesma refletia, então, minha instituição formadora, como um espelho mágico... Até que finalmente a fala de minha colega ressoa em mim ao óbvio da minha experiência de vida, mas que ao longo dos anos de formação sendo ensinada a saber interpretar o outro (muitas vezes a priori), eu me havia esquecido: ouça primeiro, pois não é possível compreender uma realidade sem antes percebê-la... Em outras supervisões, atendendo de cinco a oito clientes, ouvia o supervisor apenas perguntar: “Quem está com alguma dificuldade e quer falar?” Não era por acaso que me preocupava com o saber técnico ao me sentir participando de uma “linha de produção”...

Por outro lado, alguns estágios abriam para mim outra possibilidade: aproximando teoria e prática, possibilitavam ao mesmo tempo um fazer criativo, que se formava, por um lado, através de um olhar atento para aquele que procura ajuda, e, por outro, do pensar sobre o que se apresentava para que o fazer se inclinasse à sua demanda. Nestes espaços, muitas vezes começava-se a prática a partir de simplesmente se abrir para conhecer: olhar e deixar penetrarse pelo olhado, perceber essa afetação, discutir reflexivamente o percebido, para só então, a partir disso, pensar em formas de intervenção pertinentes... Sem desconsiderar que a presença por si mesma como intervenção, e deixar que o outro se diga como é, ao contar de sua 
vivência.

É certo que percebia ainda, às vezes, em mim e em outros alunos, uma certa confusão: acostumados a um fazer meramente técnico e muitas vezes diretivo, cuja contrapartida era um espontaneísmo estereotipado, era difícil resgatar um aprender a olhar de outra maneira, que transforma a experiência prática em reflexão teórica. Um tal aprender possibilitava um modo de fazer ao mesmo tempo consistente e transformador, conduzindo a uma recriação da própria prática para mais habilidosamente responder (respons +abilidade) às demandas do contexto em que ocorriam. Significava reconhecer, como escreveu um colega em um trabalho de disciplina: "Lá está o cliente perdido, sem respostas. Ele não sabe, mas eu também não as tenho. No entanto, podemos conversar” (NUNES, A. P., 2001). Reconhecer, dessa forma, as possibilidades abertas pelo encontro de dois estrangeiros, desconhecidos entre si.

As situações de experiência de alunos em formação, como anteriormente relatadas, podem conter diversos aspectos, dada a complexidade nelas implicada. Nesse sentido, poderiam ser compreendidas considerando-se questões políticas, econômicas, sociais, institucionais e tantas outras. Contudo, delas ressalta uma questão mais fundante, por se referir ao encontro propriamente dito. Refere-se àquilo mais vividamente próximo à experiência dos alunos: seu processo de aprendizagem como questão de perspectivas para o conhecimento e a prática do psicólogo. Nessa direção, pode ser contemplada a partir de suas inter-relações institucionais. A partir do sentido proposto para o trabalho, qual o seu diálogo e sua coerência com as formas de transmissão desta concepção de trabalho aos alunos? Que perspectivas histórico-sociais acerca do conhecer permeiam o ensino? Estas questões estão bastante próximas da vivência das instituições de ensino. Aliás, não apenas destas instituições. Em minha experiência como supervisora de práticas clínicas em clínica escola e em uma instituição sócio-educativa, muitas vezes deparei-me com questões semelhantes. 
No âmbito acadêmico, considerando a Universidade como fronteira, como eixo de investigação de práticas, podemos relacionar estas questões à tríade ensino-pesquisa-extensão. Conheço o contexto em que intervenho? De que forma? O que ele me mostra, ou o que nele posso pesquisar/conhecer? Estes contextos não são, também, os lugares por excelência da transformação em ciência, revelando em seus percalços as possibilidades de novas metodologias, teorias, descobertas? A pesquisa, sendo uma forma de produção de conhecimento, não é também um modo de aprendizagem sobre uma realidade? Como estagiários de projetos de pesquisa e extensão aprendem nas práticas que realizam?

Nestas experiências, algumas vezes, um aluno ou profissional encontrava, pelo caminho, práticas que o aproximavam de sua experiência. Isto, nas mais variadas áreas e em muitas abordagens. O que diferenciava estas experiências de outras, normativas? Que concepções elas abrangiam?

Na minha experiência, encontrei, nas práticas clínicas em instituições desenvolvidas no Laboratório de Estudos e Práticas em Psicologia Fenomenológica e Existencial (LEFE), um campo extremamente fértil, capaz de possibilitar aos alunos a compreensão deste modo de olhar e trabalhar. Ao mesmo tempo, o diálogo com alguns autores, que refletiram sobre a prática psicológica a partir de um olhar para o cliente, seja ele uma pessoa ou uma instituição, e sobre a formação, com uma concepção do professor como facilitador da aprendizagem e não como único agente ativo do processo, encontrou ressonância através destas práticas, possibilitando-me pensar acerca da formação em Psicologia e suscitando questionamentos acerca dos aspectos educativos dos estágios em práticas clínicas em instituições. Neste trabalho, um aspecto importante foi a investigação dos movimentos históricos modos de um fazer clínico contextualizado. No âmbito destes movimentos, encontra-se o Projeto de Atenção Psicológica, compreendendo diversas modalidades de práticas clínicas em instituições. Entre 
estas, o Plantão Psicológico, a partir do qual muitos aspectos do desenvolvimento desta perspectiva clínica se constituíram, revelou-se pertinente como eixo norteador desta pesquisa.

Esta modalidade de ação clínica propõe-se a desenvolver uma atitude e um modo de trabalhar que possibilite, através de suas práticas e reflexões, a apreensão e compreensão de um modo de ação que é capaz de, mantendo sua consistência, reconfigurar-se para contemplar a solicitação de uma demanda. Por outro lado, a partir de sua recriação para adaptar-se ao seu contexto de atuação, pretende, agindo neste contexto, modificá-lo. Como os alunos compreendem e trazem à presença este modo de trabalhar? Como se dá este processo? É o que me proponho, aqui, a investigar.

Em suma, esta pesquisa versa acerca dos modos de apreensão e compreensão, ou seja, dos percursos de construção de saberes, por parte de alunos de graduação, da abordagem teórico-prática do Programa de Atenção Psicológica em Instituições, desenvolvido pelo Laboratório de Estudos e Prática em Psicologia Fenomenológica Existencial do Instituto de Psicologia da Universidade de São Paulo (LEFE/IPUSP). Como modalidade de prática psicológica em instituições, a perspectiva da Atenção Psicológica apresenta uma historicidade que abrange desde um percurso e um posicionamento epistemológico, a perspectiva fenomenológica existencial, até um percurso e um posicionamento no próprio contexto das ciências humanas e da Psicologia - mais especificamente na área do Aconselhamento Psicológico no contexto brasileiro. Desse modo, tal implica em desdobramentos nas formas de transmissão de articulações possíveis entre teoria e prática em Psicologia, recorrendo-se a esta perspectiva, conduzindo a inter-relações entre os campos da saúde e da educação. 


\title{
2. Preparativos de viagem: trazendo à presença a questão do ensino de Psicologia Clínica
}

\author{
O velho poeta \\ Velho?! Mas como?! Se ele nasceu \\ Na manhã de hoje... \\ Não sabe o que fazer do mundo, \\ Das suas mãos, \\ De si mesmo, \\ Do seu sempre primeiro e penúltimo \\ amor... \\ E - quem diria? - O que ele mais \\ Teme na vida é o seu próximo \\ Poema! (...)" \\ (Mário Quintana, Preparativos de Viagem, São \\ Paulo: Globo,1994)
}

Este trabalho ${ }^{1}$ pode ser compreendido como contemplando duas vertentes. Relacionase com a questão do conhecimento, por um lado, pelo próprio tema e contexto escolhidos para serem investigados. Assim, trilha inicialmente um percurso pela pesquisa, transitando pela construção de saberes, discursos, perspectivas e fazeres. Posteriormente, segue um outro percurso pelo questionamento da relação ensino-aprendizagem, atravessando, dessa forma, a transmissão e apreensão daqueles mesmos saberes, discursos, perspectivas e fazeres.

A fim de situar o leitor no tocante aos contextos, saberes e discursos que se articulam à questão do conhecimento como pesquisa, será aqui apresentada uma breve compreensão de sua historicidade desde a Antigüidade até os dias atuais. Em seguida, é apresentado o modo como esse percurso histórico de saberes se articula com fazeres e contextos relacionados à questão da aprendizagem do psicólogo pela perspectiva do Aconselhamento Psicológico como Atenção Psicológica em Instituições.

Busca-se também apresentar alguns temas pertinentes no campo da educação e alguns aspectos de seu percurso histórico no Brasil, como forma de situar tanto o contexto de aprendizagem na Atenção Psicológica em Instituições quanto a perspectiva para a aprendizagem adotada neste estudo. Além disso, o campo da educação se apresenta 
entrelaçado à constituição da Psicologia como ciência e Profissão no Brasil, articulando-se ainda mais o campo da Psicologia às formas de produção-transmissão de saberes. Dessa forma, aborda-se também alguns aspectos do ensino de Psicologia no país, procurando compreender como articulações e concepções epistemológicas e educativas têm se efetivado no campo da Psicologia.

Ao abordar as questões relacionadas ao conhecimento no tocante à Psicologia, procurase aprofundar o entrecruzamento entre as perspectivas epistemológicas e seus desdobramentos na prática clínica para a seguir apresentar as buscas de uma prática clínica contextualizada e situar, relativamente, a perspectiva teórico-prática da Atenção Psicológica em Instituições.

\subsection{A questão do conhecimento: origem e genealogia de uma perspectiva}

A porta da verdade estava aberta, Mas só deixava passar Meia pessoa de cada vez

Assim, não era possível atingir toda a verdade, Por que a meia pessoa que entrava Só trazia o perfil de meia verdade.

E sua segunda metade

Voltava igualmente com meio perfil. E os meios perfis não coincidiam.

Arrebentaram a porta. Derrubaram a porta. Chegaram ao lugar luminoso onde a verdade resplendia seus fogos.

Era dividida em metades Diferentes uma da outra.

Chegou-se a discutir qual a metade mais bela. Nenhuma das duas era totalmente bela. E carecia optar. Cada um optou conforme

Seu capricho, sua ilusão, sua miopia. (Carlos Drumonnd de Andrade, "Verdade"In:

Corpo. RJ: Record, 1984)

\footnotetext{
${ }^{1}$ Por trabalho entende-se seu sentido etimológico de tecitura (ARENDT, 2001).
} 
A tradição do pensamento metafísico teve seu início nos ensinamentos de Platão e Aristóteles (ARENDT, 1954, 2000). O mito da caverna, de Platão, representa claramente as concepções desta tradição: estabelece uma diferença entre os assuntos humanos - esfera de travas, ilusões e confusão - e o ser verdadeiro, alcançado na esfera eterna das idéias. Esta tradição engendrou o projeto epistemológico ocidental, trazendo em seu bojo concepções sobre o que vem a ser o homem e a realidade, e qual o melhor caminho para conhecê-los. Ao longo do tempo, este projeto constituiu-se no modo dominante do pensamento no ocidente e carregou consigo uma perspectiva de matematização, conceitualização absoluta, ou, como denomina HEIDEGGER (1997), uma conversão do mundo em representações claras $e$ distintas.

Com o advento do império romano, a cultura grega passa a ganhar outro sentido, mais institucionalizado. Normatizam-se as organizações sociais e as idéias humanas. Uma forma diretamente reconhecível deste movimento encontra-se no Direito Romano. Pode-se também compreender este fenômeno através da análise do significado etimológico da linguagem. Se entre os gregos, por exemplo, cidadão era o habitante da polis, implicando, portanto, numa condição de homens livres, no Direito Romano civitas significará portador de direitos, sendo desta forma, algo conquistado nos espaços sociais, e não mais uma condição ontológica.

Na Idade Média, a conceitualização do mundo se apresentava na regulação social teocêntrica institucionalizada pelo dogma. Daí decorreu uma forma de organização fechada do modo de vida social que garantia uma forte ligação entre os sujeitos, seus grupos e mundos. É no século XVI que a abertura do mundo, cuja expressão sócio-cultural foi o Renascimento, gera uma perda das referências fornecidas pela tradição (RUDOLFER, 1936; FIGUEIREDO, 1996), típicas das sociedades holistas, nas quais os homens estavam profundamente enraizados a seus mundos, e possuíam restritas perspectivas individualizantes. Esta nova organização 
passa a exigir dos sujeitos outras formas de reconstruir crenças e regras de ação. Constitui-se uma subjetividade de homem perdido em um mundo em expansão, onde tudo é possível para ele, mas, por isso mesmo, nada lhe é próprio, que se volta então para sua experiência individual como referência para lidar com a realidade, consigo e com outros.

Este contexto não foi sem conseqüências nem para o sujeito nem para a questão do conhecimento: começava aí a engendrar-se o que viemos a conhecer como modernidade. Por um lado, cada vez mais entregue a si, este sujeito passa a recorrer às suas experiências cada vez mais consolidadas como privatizadas na tarefa de constituir referências para si mesmo. Por outro lado, a necessidade de regras que garantissem uma relativa coesão social gera, a partir do século XVII, a metodologização da vida, em diversas esferas: no campo social- pela etiqueta - no campo religioso - via Reforma e Contra-Reforma - no campo político através do Absolutismo e das Monarquias Constitucionais - no campo artístico e cultural - através da música, do paisagismo, da poesia matematizadas, expressas no Classicismo, nas Oratórias barrocas, que se colocam como verdadeiros manuais de conduta, no Arcadismo.

A instauração do método, como eixo no qual se produziam referências e idéias sobre a realidade, tanto impõe uma certa perspectiva sobre o que seja o conhecimento e a realidade, quanto sobre o que se deve esperar dos sujeitos: o método opera uma cisão tanto no plano dos sujeitos quanto no plano do conhecimento. No plano dos sujeitos a cisão opera entre a parte plenamente coincidente consigo mesma, coerente e racional, e a parte imprevisível, “emocional” e obscura (FIGUEIREDO, 1992). No plano do conhecimento, por sua vez, na separação entre "sujeito plenamente cognoscente e objeto plenamente cognoscível" (CRITELLI, 1996). Neste contexto, também a narrativa, como forma artesanal de comunicação, de troca de vivências e construção da experiência, perde seu espaço e 
legitimidade como forma de conhecimento e aprendizagem, sendo substituída pela informação - precisa, técnica, impessoal e generalizável. (BENJAMIN, 1985).

No plano social, a obediência ao método, que em sua dimensão política se apresenta em termos de obediência ao Estado, constituído como instituição regulamentadora da vida social, e o recurso às próprias experiências como referências para a ação, cria uma contradição, "resolvida” em uma separação entre público - esfera de jurisdição do Estado - e privado - esfera de jurisdição pessoal. No bojo deste processo, constitui-se o espaço psicológico - espaço que se configura como locus da experiência subjetiva privatizada, do imprevisível, do obscuro, em suma, do expurgado pelo método - dos aspectos do sujeito que não cabem na concepção de sujeito epistêmico purificado (FIGUEIREDO, 1992).

ADORNO (1985) refere-se a este processo de metodologização como esclarecimento, do qual a ciência é a formalização, e sobre o qual afirma:

\section{A sociedade burguesa está dominada pelo} equivalente. Ela torna o heterogêneo comparável, reduzindo-o a grandezas abstratas. Para o esclarecimento, aquilo que não se reduz a números e, por fim, ao uno, passa a ser ilusão: o positivismo moderno remete-o para a literatura (p.23).

Porém, este projeto epistemológico moderno, embora apresentando êxitos em termos de desenvolvimento tecnológico, não tardaria a apresentar suas vicissitudes: mesmo com as promessas de liberdade oferecidas pelo advento do método, este sujeito não se sente mais plenamente em casa, e a experiência subjetiva privatizada e o sujeito epistêmico pleno são questionados em diversas esferas. Torna-se cada vez menos confiável a idéia de que cada sujeito conseguirá, por seu esforço, razão e vontade, auto-regular a própria vida e obter 
garantias mínimas de uma vida relativamente segura. Além disso, torna-se cada vez mais difícil confiar nas virtudes ascéticas de qualquer método que tenha como função tanto garantir a objetividade e autonomia do sujeito quanto garantir a clareza absoluta dos objetos.

Neste contexto, os mecanismos de controle metodológico irão gerar o nascimento das ciências como conhecemos hoje, a partir do século XVIII. Segundo PRICE (1976), a ciência moderna se desenvolveu de modo ordenado e regular desde o auge da Verificação Científica (que teve seu centro no séc. XVII) até os dias de hoje. Um embrião da ciência moderna estava presente em Newton, Galileu e Copérnico, Harvey e Boyle, que caminharam pela rede teoriaexperimento-conceito. Antes do séc. XVI o conhecimento se construía de forma mais unificada, e não fragmentado, como veio a se tornar a partir das classificações modernas da ciência. Esta concepção de conhecimento unificado pode ser ilustrada pela figura de Leonardo da Vinci. Assim, a concepção de ciência tal como a conhecemos é relativa ao contexto social moderno. Como afirma PRICE (1976), “Nenhuma das outras grandes civilizações seguiu trilha científica semelhante (...) nenhuma delas sequer se aproximou da trilha científica” (p.20).

É neste contexto que emergem as ciências modernas em sua tarefa de previsão e controle da realidade. Segundo FOUCAULT (1997) as estratégias de controle social engendradas pelo método como investigação, observação, depoimento, etc., geraram as ciências exatas, humanas e biológicas. Para ele, as práticas discursivas têm sua transformação ligada a um conjunto bastante complexo, no qual se inserem: a esfera social, econômica, institucional; a esfera de sua inter-circulação - o aprimoramento das técnicas, o acúmulo de informação, entre outros, e esferas paralelas - outras práticas discursivas. O discurso científico, neste contexto, pode ser compreendido como originado de um imbricamento de diversos fatores do contexto histórico. Para FOUCAULT, o entrecruzamento das práticas de 
controle e do discurso metodológico terá como um de seus efeitos o desenvolvimento das ciências no século XIX. FOUCAULT associa algumas formas de construção de saber medida, inquérito e exame - à formação das ciências exatas, biológicas e humanas, que, atualizados nas práticas científicas, no papel da produção de conhecimento "tenham se separado de sua relação com as formas de poder”, mas que antes de se encontrarem “decantados no interior de domínios epistemológicos definidos, estiveram ligados à instauração de um poder político”, desenvolvidas até a formação dos Estados constitucionais modernos no século XIX, quando também ganharam uma relativa autonomia na formação dos discursos científicos.

Dessa forma, a questão do conhecimento, tanto em sua esfera de construção de concepções sobre a realidade quanto em sua esfera de transmissão a aplicação destas concepções, está articulada, sob várias vias, a questões históricas, econômicas, sociais. É a partir da desconstrução das trilhas de origem de determinada concepção acerca do conhecimento que podemos situá-lo e melhor compreender a perspectiva sob a qual uma determinada concepção é construída, bem como esclarecer seu sentido e sua proposta. É nessa perspectiva que se procurará investigar, neste trabalho, alguns aspectos relacionados à construção do conhecimento em ciências humanas, para melhor situar as compreensões que norteiam tanto o desenvolvimento da Psicologia, como ciência e prática, quanto o desenvolvimento das práticas educativas como forma de transmissão de saberes, já que são as esferas que se entrelaçam no contexto de investigação desta pesquisa. 


\title{
2. 2 Nascimento das ciências e desenvolvimento das ciências humanas: críticas a essa perspectiva
}

\author{
As Bibliotecas \\ Um dia veio uma peste e acabou com \\ Toda a vida na face da terra: \\ Em compensação, ficaram as bibliotecas... \\ E nelas estava meticulosamente escrito \\ O nome de todas as coisas! \\ Mário Quintana, Preparativos de \\ ViagemSáo Paulo Globo, 1994
}

Se o método garantiu, no plano tecnológico, uma certa eficácia, no plano humano isso não aconteceu. Ao longo do desenvolvimento das chamadas ciências humanas, a necessidade de uma perspectiva contextualizada para a compreensão dos processos sociais e subjetivos gerou críticas quanto à transposição da representação e do conceito como formas de compreensão da realidade no âmbito humano.

ARENDT (2001) demonstra essa problemática ao discutir a ciência política: para ela, tanto a razão pura quanto a razão prática têm uma estrutura discursiva monológica, que converte o discurso em verdade indiscutível. A evidência racional, a prova empírica, a verdade filosófica, a verdade moral - todas estas formas de comunicação, dizendo respeito ou a uma generalidade absoluta, ou a uma singularidade absoluta, expressam no comunicado uma perspectiva única de compreensão. A Política, no entanto, se insere num contexto de pensamento no plural, que consiste em ser capaz de pensar no lugar e na posição dos outros em vez de estar de acordo consigo mesmo: é no diálogo com outros que poderei chegar a um acordo, não se instalando um juízo de validade universal, mas de validade específica e contextualizada. Assim, ARENDT (2001) caracteriza uma estrutura discursiva dialógica presente no âmbito político, mas que podemos considerar mais amplamente, como presente no âmbito dos assuntos humanos. Neste sentido, compreender o humano - seja em seu contexto 
social, antropológico, histórico, subjetivo (caso da Psicologia), etc., implica em uma conceitualização não absoluta, em considerar que algo do humano não é absolutamente previsível ou predizível, em uma relativização de verdades.

“A história, em contraposição com a natureza, é repleta de eventos; aqui, o milagre do acidente e da infinita improbabilidade ocorre com tanta freqüência que parece estranho até mesmo falar de milagres. Mas o motivo desta freqüência está simplesmente no fato de que os processos históricos são criados e constantemente interrompidos pela iniciativa humana, pelo initium que é o homem enquanto ser que age” (p.219, grifo da autora).

ADORNO (1985) considera esta questão do ponto de vista social, demonstrando que, se o projeto epistemológico moderno possibilita, através do conceito, uma dominação do ambiente natural, ele se torna instrumento para a dominação humana, e não para sua compreensão.

No sentido mais amplo do progresso do pensamento, o esclarecimento tem perseguido sempre o objetivo de livrar os homens do medo e investi-los na posição de senhores. Mas a terra totalmente esclarecida resplandece sob o signo de uma calamidade triunfal (...) Contudo, a credulidade, a aversão à dúvida (...), o deter-se em conhecimentos parciais: isto e coisas semelhantes impediram um casamento feliz do 
entendimento humano com a natureza das coisas e acasalaram, em vez disso, a conceitos vãos $e$ experimentos erráticos.(p.19)

Assim que aos poucos as ciências sociais partem para outras formas de compreensão que, estando já presentes no plano cultural, foram ganhando legitimidade no âmbito científico. Neste sentido, muitos autores no âmbito das ciências humanas buscarão uma revisão epistemológica na qual os métodos de conhecimento não estejam calcados apenas em um rigor metafísico de gênese racional (SERRES, 1990, ARENDT (2001), ADORNO (1985), HEIDEGGER, BENJAMIN,1985), mas na qual a possibilidade do conhecimento através da experiência com o mundo seja considerada. Assim, a investigação da experiência através do contato e do trânsito das compreensões buscará "estabelecer uma política da pesquisa que abra espaço para a palavra experiente no lugar da palavra competente (CHAUÍ, 1980) ${ }^{2}(. .$. incluindo aí uma revisão ética das relações entre pesquisador e sujeito da pesquisa."(SHIMIDT,1990, p. 72).

HEIDEGGER (1997), possibilita uma outra forma de conhecer a realidade, na qual esta pode ser compreendida tendo como eixo não o conceito, mas a interrogação. Refletindo sobre HEIDEGGER, MORATO (1999), afirma que meditar sobre o que merece ser interrogado possibilita situar a realidade e o vivido, no tempo e no espaço, na historicidade humana, configurando sentido para o vivido e compreensões acerca do presente. ALMEIDA (1999) relata as implicações desta perspectiva para o conhecimento:

$$
\begin{aligned}
& \text { “(...)não é mais possível admitir o aprisionamento } \\
& \text { do homem em essência, a qual se manifesta através }
\end{aligned}
$$

\footnotetext{
${ }^{2}$ Shimidt resgata esta concepção de Chauí em seu trabalho "A experiência de Psicólogas na comunicação de Massa”, citado a seguir. Para um aprofundamento das idéias de Chauí, segue a referência original: CHAUÍ, M.
} 
de um conceito forjado por uma metodologia lógicocientífica(...) O ser dos entes (também) não é mais captado numa acepção conceitual, onde (sic.) seria imperiosa a atuação de um cogito, que, desde fora da trama de relações na qual o homem está imerso, pudesse ver com distinção a coisa a ser conhecida (...) Isso implica que o homem apreende o ser não através de conceitos: antes, no próprio ente, naquilo que é, seja algo, outro ou si mesmo.”(p., parênteses nosso, grifo do autor) .

Assim, HEIDEGGER $(1997,1995)$ repensa o paradigma de uma essência captada por procedimentos racionais como uma apreensão de um modo de ser das coisas, uma visão possível, entre outras, que se fazem na apresentação do cognoscível em sua inter-relação com o cognoscente. Dessa forma, objeto e ser, como em-si, são incontornáveis. Se toda percepção humana carrega consigo uma perspectiva de compreensão, se todo encontrar-se já é, em si mesmo, matizado, isto implica não apenas uma mundanização humana, mas na contextualização e na adoção ontológica de alguma perspectiva em todo compreender e em toda tarefa humana - a ciência inclusive.

SHIMIDT (1990) refletindo sobre BENJAMIN (1980) resgata a importância de intercambiar a experiência como via para o conhecimento na dimensão do humano. Esta dimensão escapa ao operacional e comensurável. Para a autora, a predominância da informação sobre a narrativa “Tem desdobramentos percebidos tanto no âmbito mais geral da cultura quanto no âmbito mais específico da produção do saber universitário” (p.36).

“Cultura e democracia: o discurso competente e outras falas”São Paulo: Moderna, 1980, 220p. 
Por outro lado, a dimensão do saber experiencial não é acessível à quantificação e à equacionalização, exigindo uma revisão epistemológica. Assim, “a pesquisa voltada para a experiência coloca em cena, necessariamente, a estrutura do saber narrativo” (p.37).

Esta crítica à matematização do mundo implicou "na perda de autonomia do sujeito epistêmico (...) na sua mundanização histórico-social” (FIGUEIREDO, 1995a). Estas críticas, oriundas das chamadas ciências humanas, baseadas na análise das vicissitudes do projeto epistemológico moderno, geraram, ao longo do século $\mathrm{XX}$, o florescimento de outras perspectivas para o conhecimento além do positivismo tal como se constituíra e fora estabelecido no século XIX. Embora a abordagem positivista continue a ter legitimidade, ela mesma se oxigena e se reconfigura até a atualidade, algumas vezes modificando seus critérios de validação, como na moderna substituição do critério de padronização do experimento pelo de amplitude e intensidade de eficácia do resultado. Novos modos de olhar, em outras ciências, procuraram, a partir de então, abordagens mais flexíveis em torno de seus objetos, ampliando os horizontes de compreensão (PRICE, 1976; CHELMERS, 1994).

Assim, nas próprias áreas de conhecimento até então calcadas no paradigma positivista, surge a preocupação de refletir sobre a ciência como um constructo humano. O físico e epistemólogo ALLAN CHELMERS (1994), por exemplo, afirma que "Os relatórios de observação e os resultados do experimento são produtos sociais e humanos que surgem em conseqüência da discussão e das experiências” (p.116).

No entanto, este trânsito não significou uma ressignificação das ciências humanas em relação ao status quo do pensamento positivista. Ao mesmo tempo em que há uma reconsideração desta posição epistemológica como uma compreensão possível, e não como uma leitura acabada da realidade, há a "sensação" de que a legitimação de um conhecimento ou leitura da realidade só é socialmente possível a partir do paradigma positivista. Assim, 
muitas vezes as ciências humanas têm encontros ambíguos com a tradição metafísica: por um lado, questionam seus modos de compreensão, trazendo à tona aspectos que não podem ser contemplados em uma rigidez conceitual; por outro lado, muitas vezes procuram legitimar estes mesmos aspectos pelos critérios desta tradição, já que nem sempre estes podem ser legitimados por critérios de eficácia, pelos quais, em algumas instâncias, o rigor do método foi substituído em outras ciências. Nas palavras de FIGUEIREDO (1995a)

O que se continua freqüentemente assistindo é um patético pedido de reconhecimento e legitimação por parte das chamadas ciências humanas, dirigido, nem mais nem menos, a quem vê seu espaço e seu tempo invadido por novos modos de pensar o sujeito, oriundos precisamente destas mesmas humanidades.

\subsection{Psicologia: genealogia de uma ciência}

Como explicitado, o projeto epistemológico moderno implicou na separação mente (razão, unicidade, clareza, coerência interna) e corpo (incompletude, obscuridade, finitude), o que gerou, no âmbito do conhecimento, um abismo entre sujeito e objeto. No plano social, este projeto epistemológico constituiu uma organização das relações entre sujeitos mediada pela concepção de autonomia, na qual cada indivíduo passa a ser responsável por si mesmo. Esta forma - ou ideal - de organização social que foi explicitada pela revolução francesa: o lema "Liberdade, Igualdade, Fraternidade" exprime a idéia de uma sociedade organizada por indivíduos iguais em sua autonomia, e portanto livres para organizar a própria vida, e a crença de que, sendo os homens fraternos, esta organização regularia, harmônica e espontaneamente, a sociedade. Porém, em diversos aspectos - econômico, social, subjetivo, entre outros - não 
foram garantidas ao sujeito as possibilidades de uma "existência apaziguada” (BISWANGER, 1976): as relações sociais foram se revelando menos fraternas do que o lema da revolução francesa havia idealizado. Isto levou ao questionamento da superioridade, liberdade, unicidade humanas - ou seja, o questionamento tanto do sujeito epistêmico quanto da experiência subjetiva privatizada, em seu caráter de singularidade. É o contexto destas vicissitudes do projeto epistemológico moderno que implicou, a partir do século XIX, no surgimento da Psicologia como ciência. Os projetos de Psicologia que começam a emergir no século XIX guardam estreita relação com os aspectos do sujeito expurgados pelo método, seja para seu controle e "cura”, seja para uma expressão e desvelamento da cisão, uma sua genealogia.

Neste sentido, podemos compreender os diversos sistemas teórico-práticos que constituem o campo atual das psicologias através de sua relação com esta cisão: de um lado, psicologias que terão a perspectiva de, resguardando a cisão provocada pelo método e afirmando a racionalidade do sujeito, procurar "limpar" o expurgado quando este se apresente e se revela por entre o conjunto coerente da representação; de outro, psicologias que buscarão um desvelamento desta cisão, resgatando não apenas o expurgado, mas procurando compreender a condição dividida do sujeito, realizando assim uma crítica ao método.

Pode-se compreender esta questão através da análise do nascimento e desenvolvimento dos diversos projetos de psicologia a partir do século XIX. Se Wundt, ao fundar o primeiro laboratório de psicologia, colocará o homem em uma posição intermediária entre natureza e cultura, muitos de seus seguidores realizarão projetos de psicologia com uma concepção de homem como organismo, exclusivamente biológica. Permeando esta concepção, está a possibilidade de um estudo do homem através do método, de uma consideração exclusiva do observável e previsível. Neste sentido, não apenas a concepção de sujeito é a de um sujeito previsível e claro, mas também a concepção de um conhecimento legítimo relaciona-se a 
busca de universalização e objetividade. Assim, o projeto de psicologia de Titchener e a Psicologia Funcional buscarão uma compreensão completa do humano. A hipérbole desta concepção pode ser encontrada no romance Admirável mundo novo, de Aldous Huxley história de uma sociedade que se pretende completamente clara, onde, desde a forma de concepção dos indivíduos, inteiramente organizada pela engenharia genética, passando por seu condicionamento desde a primeira infância, levam à sua posição rígida na organização social. Até a morte tem data marcada para ocorrer, e o tempo não deixa marcas: técnicas que deixam o corpo jovem até os 60 anos, e a morte obrigatória depois, eliminam a possibilidade de qualquer vestígio de impureza.

Por outro lado, o desenvolvimento da Psicanálise, do desenvolvimento cognitivo de Piaget, da Psicologia da Gestalt, se desenvolverão como projetos de Psicologia que buscarão uma compreensão do homem para além do representado, observado e previsível. Além disso, partirão de uma concepção de conhecimento legítimo a ser buscado de forma contextualizada.

Deste modo, a concepção da possibilidade de uma investigação no âmbito da clínica, do individual, engendrada por Freud, e que se tornou um dos pilares das diversas teorias e práticas psicanalíticas, é permeada pelas noções de que é possível a constituição de um conhecimento legítimo pela investigação de uma subjetividade particular e de que este conhecimento caminha em uma dada perspectiva, em uma dada interpretação. Da mesma forma, as teorias psicanalíticas apresentam um homem incompleto: a própria acepção da dualidade consciente/inconsciente conduz a uma compreensão de que o homem não é totalmente claro a si mesmo. É neste contexto que a possibilidade de uma investigação clínica faz sentido: se há coisas no homem que não são percebidas por ele próprio, se o homem é singular e plural ao mesmo tempo, compreender esta inter-relação implica em um inclinar-se ao humano, a cada subjetividade. Nesta diretriz, está implícita a impossibilidade de uma 
apreensão completa do humano, assim como é inapreensível o inconsciente. Por outro lado, isto não significa uma falta e rigor: o detalhamento dos relatos clínicos de Freud, por exemplo, ilustra esta questão. Um outro aspecto a ser apreciado é a consideração de uma inter-relação entre sujeito e objeto, de que o investigador da realidade subjetiva influenciará a realidade a qual investiga. Freud (1969, apud. PRISZKULNIK, 1995) explicita este aspecto ao afirmar que “... pesquisa e tratamento coincidem” (p.143).

A concepção, por exemplo, da Psicologia da Gestalt, de que o percebido é também dependente do percebedor, não havendo uma relação linear, contesta tanto a separação sujeito objeto quanto a generalização, a conceitualização universal, concebidas pela tradição metafísica.

Nesta concepção, a posição histórica destas psicologias é exatamente a de uma crítica ao positivismo científico e sua epistemologia. Apesar disso, muitas de suas idéias continuam a permear as questões relativas à produção de conhecimento no que se refere à sua legitimação bem como sua pesquisa, embora recusando o rigor metodológico positivista, prendia consigo um reconhecimento epistemológico calcado nesta tradição. Nas palavras de FIGUEIREDO (1995a)

No miolo deste mal-entendido, o que se passa em torno da psicanálise é paradigmático. (...) Nenhum sistema teórico foi mais longe que a psicanálise no descrédito do autodomínio, no descentramento e na dissolução da unidade do sujeito(...). Não obstante, desde Freud até os dias de hoje, uma preocupação da psicanálise tem sido a de ser reconhecida como ciência diante de algum tribunal epistemológico. (p.21) 
Pode-se compreender que um dos aspectos a ser considerado relativamente a este fenômeno é o de que o surgimento da ciência e da psicologia é, de certa forma, o surgimento de instituições, havendo, assim, também uma certa institucionalização das concepções, engendrada pelo método e pela conceitualização matematizável: o método e o conceito são, no projeto epistemológico moderno, a um só tempo formas de construção de leituras, ou percepções da realidade e formas de institucionalização, de engessamento, dessas leituras e percepções. Dessa forma, as possibilidades de compreensão da realidade, expressas através de teorias, experiências, etc., tendem a transformar-se em modelos técnicos ou, mais que isso, em verdades que reduzem a possibilidade de vislumbrar novos aspectos. Se este é um movimento possível, presente nas e próprio das formas de conhecer modernas, assim como o são as inúmeras tentativas de ao mesmo tempo, criticar e refletir sobre as vicissitudes destes movimentos e criar novas vias de construção de percepções, estes dois fenômenos construção/engessamento e crítica/criação - se expressarão também na transmissão das percepções e compreensões da realidade, bem como nos meios considerados legítimos para perceber, compreender e comunicar. Dessa forma, considerando investigação e transmissão como momentos diferentes na elaboração do conhecimento, este movimento presente nas ciências estará também presente nas práticas educativas, como veremos a seguir.

\section{Práticas Educativas}

Estes acontecimentos e concepções históricas que engendraram o nascimento das ciências também não foram sem conseqüências no plano das práticas educativas: segundo BYINTON (1996), o “modelo vivencial do aprendizado”, adotado nas sociedades holistas, foi substituído pelo método, separando também, no plano educacional, objetivo - como 
característica intrínseca à constituição de verdades - e subjetivo - como o aspecto não confiável que induziria ao erro.

O próprio modo de formação e institucionalização das escolas, que, cada vez mais, articulam o ato de aprender ao conceito, e não ao processo de aprender, atrelam a aprendizagem à informação, à institucionalização de conceitos aplicáveis. Se, entre os gregos, a aprendizagem se dava através do acompanhamento de um pensador, já na sociedade romana a aprendizagem era institucionalizada. A partir da oficialização do cristianismo, as instituições educacionais romanas passam para o controle cristão, tendo como objetivo formar cristãos e sendo, portanto, escolas catequéticas (LOUREIRO, 1992). Ou seja, aí já se vê a escola como passadora de dogmas, e portanto, a importância da perspectiva de uma conceitualizaçãomatematização da realidade. Com as invasões bárbaras e a migração para o campo, essas organizações de ensino transformam-se, aos poucos, em organizações religiosas durante o início da Idade Média, com a escola atrelada à Igreja. A educação institucional passa a ser reduzida aos membros do clero, dentro dos mosteiros. Esta situação de distinção social também provoca outra distinção - a separação entre portadores e não portadores de um conhecimento válido, as funções sociais bem definidas nas quais o trânsito de papéis é dificultado. É a partir da baixa Idade Média que se reestimulam os interesses culturais e se iniciam e desenvolvem as profissões de nível superior, com o início do estabelecimento das Universidades. No século XIV, auge do Renascimento, a reforma protestante desatrela o ensino universitário das igrejas - escola como formadora de pessoas capazes de utilizar um método - modo de produção. Ao longo do desenvolvimento das escolas e das teorias de educação no século XX, essas perspectivas vão tomando diferentes formas, mas em sua maioria continuam atreladas ao conceito. 
Na pedagogia tradicional, na escola nova e na pedagogia tecnicista (SAVIANI, 1997; PATTO, 1997), suas concepções destituem a dialogicidade da relação pedagógica. Entre elas, as idéias de que o desempenho do aluno depende de seus méritos pessoais e de que a escola está dissociada de seus condicionantes sociais, os próprios objetivos da educação como formadora de profissionais para o mercado e, portanto, de indivíduos capazes de reproduzir conceitos externos incorporados neles através do processo educativo. Mesmo Bourdieu, Althusser e Marx compreendem a escola como Aparelho Ideológico do Estado e, portanto, como reprodutora de conceitos. Ao fazê-lo, impossibilitam uma apropriação do aprendido: a própria idéia da escola como um aparelho já destitui o humano, a experiência, a possibilidade de criação e de apropriação de outras possibilidades para o humano do cerne da relação pedagógica. Estas teorias não são conhecidas como Crítico-Reprodutivistas por acaso: a idéia de que a educação institucionalizada funcione como um modo de reprodução dos conceitos sociais dominantes, não podendo ser destituídas deste papel, já carrega uma perspectiva de impossibilidade de transformação e de construção de novas possibilidades no processo de aprendizagem, e já coloca professores e alunos em papéis estáticos.

É a partir da pedagogia crítica (SAVIANI, 1997), que considera a contextualização da escola na sociedade capitalista, mas que também considera suas relações como diacríticas, ou seja dominadores também são dominados por sua própria dominação, que se pode pensar a escola e a relação pedagógica como capazes de reproduções exclusivamente conceituais, mas capazes também de transformações destes mecanismos, de modo a construir um conhecimento compartilhado e co-operado.

O processo de repensar essa questão passa também pelas mesmas confusões por que passou a Psicologia. No próprio campo da educação, de forma coerente com o processo histórico da Psicologia, muitos dos objetivos e das concepções acerca da diretividade da 
relação pedagógica são questionados e transformados. Mas, da mesma forma, pensar a prática educativa como uma prática dialógica, após dois mil anos de valorização do conceito como algo externo e de separação entre sujeito e objeto do conhecimento, não é tarefa fácil. Assim, ROGERS (1967, 1983, 1985), por exemplo, é claro ao afirmar que, em relação às aproximações da teoria centrada no cliente para a educação, esta deveria ser bastante diversa do que é hoje. Dessa forma, afirma que

“(...) aquilo que se pode ensinar a outra pessoa não tem grandes conseqüências, como pouca ou nenhuma influência significativa sobre o comportamento. (...) o único aprendizado que influencia significativamente o comportamento é o aprendizado autodescoberto, autoapropriado”.(1983, p.98)

Esta perspectiva possui uma séria implicação no campo da educação: a de que uma aprendizagem que tenha também o caráter de formação dá-se pela vivência e pela busca de sentido para ela, formando o arcabouço da experiência sobre o qual pode-se encontrar o modo próprio do educando lidar com aquilo que ensina. Porém, embora se anteveja aí uma crítica à diretividade, quando ROGERS propõe uma não diretividade absoluta, na qual o que deve ser aprendido passa exclusivamente pelo educando, de novo ele cai na separação sujeito-objeto e na monologicidade, apenas deslocando seu foco: se antes o aluno se colocava como pura passividade e o professor, portador do conceito, como pura atividade, agora, o aluno, na condição de portador da experiência, se transforma em único agente ativo do processo, e os papéis se invertem.

SCHIMIDT (1990), relendo BENJAMIN, expressa alguns efeitos da valorização histórica do conceito puro para todos os âmbitos, ressaltando a importância da criação 
artesanal do próprio sujeito. Para ela, no domínio exclusivo da informação, a elaboração e utilização do conhecimento fica sujeita à combinação imaginativa e rápida das informações e à criação de novas regras combinatórias. Esta capacidade de realização destas operações transcende a transmissão e o acesso à informação e perpassa pela busca de soluções. Assim, o ensino deve promover " $a$ aprendizagem de todos os procedimentos capazes de melhorar a capacidade de conectar campos que a organização tradicional dos saberes isola (...)” (LYOTARD, 1988, apud. SHIMIDT, p. 123). Deste modo, a investigação, a configuração de sentidos, e o estabelecimento de relações no âmbito de sua prática torna-se relevante para a elaboração de metodologias de ensino, favorecendo apropriação do aprendizado em seus entrelaçares com o outro e com a experiência.

SERRES (1993), ao discutir a experiência de aprendizagem como uma experiência de mestiçagem, também se coloca no entrecruzamento entre o olhar do professor e do aluno, do terapeuta e do cliente. O reconhecimento do que é múltiplo, um andar constantemente destituído de um lugar fixo onde se apoiar, estão implicados na experiência clínica. Para aprender, é necessário que o sujeito se afaste de seu lugar fixo de apoio para mergulhar no que é novo, para que esta novidade possa, também, constituí-lo, mesclar-se àquilo de que ele já é. Para aprender, é necessário lançar-se (novamente) sobre o novo.

FREIRE (1985) possibilita um maior questionamento acerca do fazer pedagógico quando analisa as formas instituídas desse fazer. Considerando o modo pelo qual a relação de aprendizagem reproduz relações de opressão, onde o professor, sendo portador de um saber que deve passar a alunos passivos no processo, é alçado a uma posição superior ao aluno, FREIRE (1985) critica os aspectos e conseqüências dessa forma de atuação. Em primeiro lugar, esta concepção desconsidera a experiência do aluno e o conhecimento adquirido por ele 
através de sua experiência. Além disso, este conhecimento adquirido não é apropriado pelo educando, tornando-se uma "verdade" estranha a ele, embora interiorizada.

Assim, em sua proposta, FREIRE (1985) procura contrapor-se a essa forma de pensar a aprendizagem. Coloca então a importância de se ter como ponto de partida, a experiência do educando e o diálogo como forma de refletir acerca desta experiência e construir um conhecimento próprio a este, resgatando a importância do aluno como agente da aprendizagem.

GENDLIN (1973), ao conceituar a aprendizagem significativa, resgata a importância do sentido experiencial para a formulação de significados articulados, ao mesmo tempo em que explicita a relevância da linguagem em nosso experienciando, ou seja o fluxo sensível e concreto para o qual se pode atentar a cada momento. Assim, traz o espaço inter-relacional como cena das reconstruções e da fluidificação de significado. Segundo ele (GENDLIN, 1962, apud. MORATO, 1989), “Significado é formado na interação entre o experienciando e algo que funciona simbolicamente. Sentimento sem simbolização é cego, simbolização sem sentimento é vazia” (p. 79).

Nestas concepções, percebe-se o enfoque dado para a intersubjetividade como a cena na qual se desenrolam os fenômenos humanos. A importância da intersubjetividade é resgatada, no plano filosófico, por Maurice Merleau-Ponty, que, desconstruindo as concepções sobre apreensão do mundo da fenomenologia Hursseliana, focaliza a multiplicidade de olhares sobre o real e a articulação interacional de significados, movimento que culmina com a Fenomenologia da Percepção. Não por acaso, os trabalhos de Gendlin, Paulo Freire, Michel Serres e mesmo Arthur Benjamim são muitas vezes articulados a uma perspectiva fenomenológica. Ressalvadas as diversidades teóricas, a possibilidade de se resgatar a importância do âmbito intersubjetivo na dimensão humana possibilitará a reorientação da 
pesquisa, das práticas e dos conceitos nestas mesmas humanidades, tendo repercussões inclusive nas ciências sociais, por exemplo, na vertente da sociologia denominada Psicossociologia.

Dessa forma, permite também reorientar as práticas educativas e psicológicas que, como fundamentalmente humanas não podem deixar de considerar a dimensão intersubjetiva e necessitam de um olhar que traga `a tona a expressão das multiplicidades possíveis do real e da prática. Este movimento de transcedência da prática de transmissão de saberes meramente absorvidos pelo aluno em direção à possibilidade de construção de saberes coletivos tem, no plano da educação, seus reflexos e construções próprias no Brasil afetando posteriormente a própria institucionalização do ensino de Psicologia. Visando situar o contexto de aprendizagem de práticas clínicas investigado neste trabalho, um breve histórico das idéias educacionais no país será apresentado a seguir.

\subsection{A construção histórica de uma pedagogia libertadora no Brasil: avanços e percalços das idéias educacionais}

O primeiro movimento pedagógico no Brasil pode ser denominado, segundo Franco (2001) como uma Pedagogia Filosófica, iniciada pelos jesuítas e que perdurou até o período republicano, com uma concepção essencialista do homem, e privilegiando a memorização e a repetição de exercícios, além de estar dissociada dos problemas da realidade brasileira. Esta pedagogia, que atendia a uma sociedade elitista, escravocrata e aristocrática, marca o pensamento educacional brasileiro, e só começa a ser reconfigurada a partir das transformações sociais, principalmente depois de 1930, em que integra influências da Escola Nova, no bojo das tendências tecnológicas dos estudos pedagógicos americanos da época. 
A partir de então, as concepções educacionais brasileiras passam a gravitar em torno da concepção técnico-científica, embora ainda de forma indefinida, que permeará a prática pedagógica brasileira e irá configurar, por exemplo, a estruturação dos cursos de Pedagogia. Neste contexto, tomam espaço influências românticas, pragmáticas e experimentais e o pensamento educacional entrecruza-se com a biologia, a psicologia e a sociologia. As concepções educacionais sofrem uma forte influência da psicologia e da sociologia, de forma acrítica. Alguns pressupostos presentes nestas duas ciências irão nortear teorias de educação com uma concepção tecnicista. Com o advento da Escola Nova as preocupações educacionais vão abandonar o terreno político e centrar-se no âmbito técnico-pedagógico, desconsiderandose o aspecto da educação como reflexão, como orientadora da formação de cidadãos, como crítica de ações educacionais.

Assim, por exemplo, os cursos de Pedagogia criados em 1939, durante a ditadura Vargas, se destinarão a formar técnicos e professores (PATTO, 1992), que serão, nas palavras de FRANCO (2001) "organizadores de instrução, operadores de sala de aula”.

A partir da década de 60, surgem experiências que refletem uma nova postura epistemológica em relação à educação. Por um lado, nos ginásios vocacionais contrapunha-se aos pressupostos tecnicistas da educação, concebendo o ensino como a busca de um saber contextualizado e fundado na experiência, que implica a exploração dos vários sentidos da percepção humana. Assim, buscavam superar o ensino livresco e sua organização fragmentada, adotando uma prática centrada no processo e na construção da dialética do saber, a partir da descoberta e da constituição significativa da aprendizagem. Nesta perspectiva, aprender significa sempre pesquisar e apropriar-se do processo.

Por outro lado, se constitui nesta época a proposta pedagógica de Paulo Freire. Seu trabalho com a educação de adultos carrega um rompimento epistemológico e político com a 
intencionalidade da educação vigente no país, contrapondo-se ao pressuposto de uma educação como inserção na cultura letrada através da concepção de educação como instrumento do educando para ressignificar sua humanidade, sua atuação e seu lugar na realidade. Assim, educar deixa de ser tomar posse de uma cultura estranha para tornar-se um fazer interpretador e produtor de cultura. Desta forma, na proposta de Paulo Freire (1987) a educação configura-se como ato político que organiza a intencionalidade do ensino a partir do sujeito e sua experiência no mundo.

Após o golpe militar de 1964, estas experiências pioneiras foram abortadas, assim como todo o processo de participação e organização estudantil. O contexto político ditatorial acentuou no Brasil as práticas educativas encontradas na concepção técnico-científica e enfraqueceu os processos culturais e criativos de uma identidade e uma educação brasileira que emergiram em construção na década anterior (FRANCO,2001; PATTO, 1992). Neste período, a tecnologia invade o educacional, aliada ao mito do fazer competente, substituindo a possibilidade do fazer crítico e reflexivo. Assim, se antes a concepção do tecnicismo produtivista encontrava-se ainda difusa, agora ela aos poucos vai se tornando um padrão a atingir. Em conseqüência, são retomados os pressupostos da fragmentação das ações educacionais, da educação administrativa e de especialidades técnicas.

Nas duas últimas décadas, evidenciou-se a questão da necessidade de reflexão sobre os processos de educação na sociedade. Para isso, contribuíram os debates que foram se organizando a partir doa anos 80, nos movimentos de educadores comprometidos com uma formação transformadora da realidade social. Relacionada a estes avanços está a abertura democrática, a qual, na medida em que ocorre, vai gerando novos questionamentos e percepções, que vão sendo incorporados ao pensamento sobre a educação.

Estas discussões possibilitam também o entrelaçamento de diversos saberes advindos 
de outras áreas do conhecimento, como as reflexões sobre o papel da escola numa sociedade capitalista, oriundas da sociologia e as contribuições das psicologias "não diretivas e libertárias” (FRANCO, 2001), que recolocam o papel do sujeito na construção de si mesmo e de sua percepção sobre o mundo.

Estas interfaces geraram, nos anos 80, discussões sobre as teorias não diretivas, de um lado, e teorias de conteúdo crítico, de outro. Neste contexto, também surge um outro circuito de discussão, de uma educação libertadora, através da psicogênese de Emília Ferrero, da retomada dos estudos de Paulo Freire e do crescente interesse pelo construtivismo de Piaget, Vygostsky e Wallon.

Após 1984, dentro dos governos democráticos, muitas políticas públicas organizadas a partir destes discursos e propostas fracassaram. Este fenômeno trás compreensões importantes sobre a necessária inclusão dos participantes da prática no processo de mudança de suas perspectivas e ações. Estas percepções reafirmam que processos emancipatórios não são doados, nem induzidos, mas devem ser requeridos e desejados, o que ocorre após a consciência crítica dos sujeitos no conhecimento de suas circunstâncias.

Embora muitas vezes a compreensão dialética da relação de aprendizagem estivesse presente nas próprias teorias libertadoras, esta concepção nem sempre foi contemplada na práxis. Isto se relacionou à implantação de práticas pedagógicas sem a participação do corpo docente que, efetivamente, trabalhava nas escolas. Assim, uma das questões importantes levantadas por teorias que induziram correntes pedagógicas libertadoras foi a percepção de que a educação se dá na mediação do sujeito com o mundo. É neste contexto que se encontra, também a pertinência do crescente interesse pelo construtivismo e pela proposta de Paulo Freire, entre outras.

Frente a este panorama, faz-se necessário questionar os percalços encontrados na 
possibilitação teórico prática de propostas educacionais que se pretendam inovadoras. Assim, serão relatados, sucintamente, a proposta de Paulo Freire e o construtivismo pedagógico baseado em Vygotsky. Este relato busca melhor compreender as propostas pedagógicas libertadoras e possibilitar questionamentos acerca dos percalços ainda encontrados no fazer educacional, através da reflexão, principalmente, do papel atribuído à linguagem por estes autores e da necessidade do envolvimento do educando no processo. Estes dois autores foram escolhidos por sua representatividade nos discursos pedagógicos atuais.

Em sua proposta, FREIRE (1987) procura contrapor-se à forma tecnicista de pensar a aprendizagem, denominada por ele como “educação bancária”. Coloca então a importância de se ter, como ponto de partida na aprendizagem, a experiência do educando e o diálogo como forma de refletir acerca desta experiência e construir um conhecimento próprio a este, resgatando a importância do aluno como agente da aprendizagem.

Para Freire, a educação como prática da liberdade postula uma pedagogia não para, mas do oprimido, na qual o educando tenha condições de, reflexivamente, descobrir-se e conquistar-se como sujeito de sua própria destinação histórica. Aprender é aprender a dizer a sua palavra e alfabetizar tem o sentido de aprender a escrever a sua vida, como autor e testemunha de sua história. Assim, a pedagogia articula-se à antropologia, na medida em que se relaciona ao processo de constituição histórica da própria existência humana e, por conseqüência, a uma política, já que é participante das contradições da aventura histórica. Os rumos deste processo são possíveis projetos, e dessa forma, a conscientização não é somente conhecimento ou reconhecimento, mas opção e compromisso. Esta abordagem da educação é relatada por FIORI (apud FREIRE, 1989) ao comentar a proposta de Paulo Freire:

“Um mínimo de palavras, com a máxima polivalência fonêmica é o ponto de partida para a 
conquista do universo vocabular. Essas palavras, oriundas do próprio universo vocabular do alfabetizando, uma vez transfiguradas pela crítica, a ele retornam em ação transformadora do mundo." (p.12)

Como as palavras do universo vocabular do educando são significações constituídas ou re-constituídas em seus comportamentos, configuram situações existenciais ou nelas se configuram. O alfabetizando ganha distância para ver sua própria experiência e re-conhecê-la. É este processo que lhe possibilita começar a descodificar.

Esta descodificação é análise, bem como reconstituição do vivido e, assim, é reflexo, reflexão e abertura de possibilidades de ultrapassagem. Mediada pela objetivação, a experiência antes imediata torna-se lúcida interiormente, podendo refletir a si mesma e possibilitando a crítica e a constituição de novos projetos existenciais. Nesta abertura a consciência se constrói como consciência crítica, já que “passa a escutar os apelos que a convocam além de seus limites” (p. 13). Tanto o conteúdo quanto a forma daquilo que o homem fala e escreve são expressão objetiva de si mesmo. Assim, o homem redescobre a possibilidade de refazer aquilo que fez de si, pela e na redescoberta do movimento que o faz e refaz. Ao propor a possibilidade de descodificação do representado e comunicado pela palavra, Paulo Freire resgata o locus do sujeito em sua possibilidade de refletir a si mesmo e ao mundo.

A palavra geradora, mesmo objetivada na condição de simples palavra escrita, não pode libertar-se de seu dinamismo semântico e de sua força paragmática. É desta articulação que o educando se faz consciente na descodificação crítica, possibilitando-lhe não se deixar aprisionar nos mecanismos de composição vocabular. Pensar o mundo é julgá-lo, e o educando não copia palavras, mas expressa juízos, tentando de certa forma reproduzir o 
movimento de sua própria experiência. O alfabetizando, ao dar forma escrita à sua experiência, vai assumindo a consciência de autor e testemunha de sua história. Neste sentido, Paulo Freire resgata toda a força da palavra e da linguagem, ao mesmo tempo organizadora e perspectivante. A linguagem matiza a realidade em sua organização semântica e fonêmica e a educação pode possibilitar pela conscientização deste processo a reapropriação da palavra como um dizer de si mesmo e como instrumento de construção de história e de cultura.

Para Freire, esta conscientização é fundamental, pois “os homens se propõe a si mesmos como problema e descobrem que pouco sabem de si, de seu lugar no mundo.”(p.29) Essa constatação implica o reconhecimento da desumanização, não apenas como possibilidade, mas como realidade histórica. Quando Freire faz referência à desumanização, está exatamente colocando a questão da humanidade na consciência de si mesmo, no fazer-se dos homens como “seres para si”. Para ele, as possibilidades de humanização e desumanização histórica são conseqüência dos homens como seres inconclusos e conscientes desta inconclusão.

Assim, a humanização só pode se dar na medida em que se retoma a construção do homem como "ser para si”. É neste sentido que se pode entender o papel fundamental da dialogia na proposta freiriana. Quando Freire afirma que “Ninguém educa ninguém, ninguém educa a si mesmo, os homens se educam entre si, mediatizados pelo mundo.” (p.68), considera a educação como um processo recíproco, no qual a formação não se dá de forma unilateral, mas por uma troca como forma possível de cada homem fazer-se a si mesmo. Etimologicamente, diálogo se origina da junção das palavras gregas dia (dois) e logos (que tem o sentido de razão, mas também o de dizer, utilizado na composição semântica de dialogia). Assim, a compreensão dialógica significa uma imersão na linguagem que é, também, sua tecitura. 
Porém, como compromisso, para que este processo ocorra, implica decisão e busca. Assim, é preciso que o próprio educando, como agente ativo do processo, comprometa-se com sua educação. Para Freire a motivação subjacente à educação como escolha faz parte da ação, necessita estar dentro do próprio ato. Assim, por exemplo, ela deve estar "dentro do conhecimento, pelo estudante, da importância que o conhecimento tem para ele “ (FREIRE \& SHOR, 1986, p. 15).

Através do desenvolvimento de um olhar não conceitualizante do conhecimento, foi possível um repensar das concepções de saber. Assim, para CAMPOS \& CURY (1997), em uma perspectiva desconstrutora dos objetos de investigação e pesquisa,

O saber não pode ser mais encarado como depósito enciclopédico, na medida em que ele não ocupa um ponto fixo, (...), nem pode o educador ser visto como aquele que detém o saber, mas antes, aquele que fará circular os saberes (Barthes, s.d.), aí incluído o seu próprio. (p. 1) Grifos da autora.

Visando compreender as concepções e práticas engendradas no modo de aprendizagem investigado no contexto de pesquisa, apresenta-se a seguir uma discussão acerca das formas através das quais as concepções acerca do conhecimento científico, ensino e Psicologia, principalmente em sua vertente clínica, entrelaçaram-se na constituição do ensino de psicologia como profissão. Não se pretende aqui esgotar a questão, mas apenas levantar alguns elementos que possam subsidiar a compreensão da Atenção Psicológica em instituições no que refere às sua concepção epistemológica, que permeia tanto sua investigação e sua prática clínica como suas possíveis formas de aprendizagem na formação, tema de investigação deste trabalho. 


\section{2. Ensino de Psicologia}

As esferas relativas à formação das perspectivas possíveis para o conhecimento, da Psicologia como ciência e profissão e da trajetória histórica das práticas educativas, e sua posição relativa em referência ao projeto epistemológico moderno, confluem quando se considera o ensino de Psicologia: ensino - âmbito no qual repousam todas as dimensões de uma prática instituída em substituição ao “modelo vivencial do aprendizado” BYRMAN (apud SCHIMIDT, 1989), vindo de encontro ao rigor metodológico e ao controle disciplinar - de Psicologia - a ciência e profissão nascida de diferentes relações como o expurgo dos aspectos imprevisíveis do sujeito, que lidará com a dimensão experiencial, não representável, obscura deste sujeito moderno. Cabe ressaltar que, assim como ocorre com a pesquisa científica, o ensino centraliza-se na questão do conhecimento e, portanto da epistemologia: o caminho adequado para vir a conhecer.

Uma outra questão a ser considerada é a de que a possibilidade de ensino de Psicologia surge, historicamente, junto ao nascimento da Psicologia como ciência, ou seja, no século XIX. Surge, portanto, em um momento em que a transmissão do conhecimento já se dá através de instituições na sua formulação moderna, calcada nas organizações. Segundo BLEGER (1998), quanto mais um grupo tende a estabilizar-se como organização, “mais tende ao objetivo de existir por si mesmo, margeando (...) a este objetivo o objetivo do grupo” (p.115). Em todas as organizações, “os objetivos explícitos para os quais foram criadas correm sempre o risco de passar a um segundo plano, passando ao primeiro plano a perpetuação da organização como tal” (p.115). Neste contexto histórico, uma tendência à institucionalização do ensino de Psicologia, no sentido do engessamento cada vez maior de "padrões, normas e estruturas que se organizam ou que já vêm organizados de uma maneira dada” (p.103), foi favorecida. 
A educação atual, neste contexto, partiu de uma perspectiva diretiva em relação ao educando, na qual as metodologias pedagógicas são também diretivas. Consideram, portanto, o professor, e algumas vezes apenas o aluno, e não a transitividade de um processo construído em conjunto, como agente central da aprendizagem. É através de muitos questionamentos que estas perspectivas são revistas, gerando novas formas de pensar a educação.

Para os sistemas psicológicos que buscam uma simples previsão e controle dos sujeitos, garantindo e afirmando a cisão promovida pelo método, é coerente tanto uma pesquisa quanto um ensino pautados nas mesmas idéias A concepção do locus destas Psicologias foi, a princípio, como sendo o de controle e avaliação dos indivíduos, principalmente no âmbito da saúde mental e da educação escolar, tendo, portanto, como consequiência, o desenvolvimento dos testes psicológicos e de teorias diretivas de aconselhamento, entre outros (FIGUEIREDO, 1995a; MORATO, 1999, PATTO, 1984). Apresentava-se, como decorrência, uma formação profissional norteada pelo ensino, qualificado e padronizado, de tais técnicas de avaliação e orientação.

Por outro lado, questionamentos surgem em relação a sistemas psicológicos que procuram recuperar a dimensão experiencial do sujeito. A Psicanálise, desenvolvida como um campo à parte, até certo ponto, com uma perspectiva de compreensão desta cisão, de um ir além do plenamente representável, vai, ao longo do século XX, transformando-se também em instituição, e clamando para si um status de conceito, no sentido ortodoxo, a suas idéias.

Embora, por exemplo, Freud tivesse escrito textos relativos à técnica em psicanálise, estes textos visavam, segundo FIGUEIREDO (2001), exatamente dissuadir a "banalização tecnicista” que a Psicanálise sofria, já que os artigos de Freud sobre a técnica, por exemplo, foram, muitas vezes, adotados como verdadeiros manuais de conduta do analista, principalmente nos Estados Unidos (COUCH, 1997). Ao mesmo tempo, Freud possuía a 
preocupação de legitimar a Psicanálise como ciência, do que decorreram, também, rupturas ligadas a uma necessidade de ortodoxia teórica, como as ocorridas com Carl G. Jung e W. Reich.

Em relação à produção de conhecimento, a busca de legitimação científica da Psicanálise tornou-se, muitas vezes, tanto em termos de pesquisa quanto no ensino, uma metodologização do conceito: uma prática cujo objetivo era "curar" os indivíduos através da fala, buscando o sentido de seu sofrimento em uma construção teórica pré-definida, partindo de um diagnóstico realizado em entrevistas iniciais acerca da personalidade do indivíduo, e ampliando perspectivas para o conhecimento justamente às quais a Psicanálise, a princípio, criticava. Assim, algumas vezes, no engessamento da técnica, perde-se a dimensão ética, referencial, "entendida como posição e como lugar (morada), (...) como modo de escutar e falar do outro em sua alteridade - a alteridade do inconsciente.” (p. 7).

Assim, sua formação foi se calcando em grande parte no ensino de maneiras de diagnosticar e interpretar o sofrimento à luz de determinada construção teórica psicanalítica, procurando aproximar o aprendiz da técnica clínica para tratamento (PATTERSON, 1973; FIGUEIREDO, 1995a). Na concepção Freudiana que, ao mesmo tempo, procurava legitimar a psicanálise como ciência e buscava o estabelecimento de um conhecimento não pautado na separação entre sujeito e objeto, a condição básica para formar-se analista era ser analisado, ou seja, passar pela experiência de análise. Aos poucos, com a institucionalização da psicanálise, começa-se a dar mais importância ao ensino de conceitos psicanalíticos e de "regras de conduta” que engessaram, em grande parte, a postura analítica.

Freud afirma (apud ROMERO, 1993) que o fundamental em sua teoria são os conceitos de transferência e contratransferência e que toda metapsicanálise serve apenas como instrumento de legitimação e organização do pensamento, ou seja, como possibilidade de 
reflexão que esclareça novas possibilidades para a prática analítica. Porém, até pela questão da legitimação, a psicanálise vai passando por um processo, em sua história, de superdimensionamento da teoria e da técnica, muitas vezes em detrimento da experiência, que ROMERO (1993) chegou a denominar “desobediência parcial a Freud”.

Na história da psicanálise, muitas vezes esta questão da ortodoxia voltará à tona. Em alguns contextos, privilegiando uma metodologização, como ocorrido a partir da perspectiva Kleiniana de valorização transferencial, que favoreceu posturas de imposição interpretativa, nas quais o olhar para a alteridade e o desconhecido, a possibilidade de abertura, acabaram prejudicados. Em outros momentos, a discussão se voltará ao favorecimento desta mesma abertura para novas possibilidades a partir do real, sem perda de uma articulação teórica como ocorridas nas discussões de WINNICOTT (1984) sobre as possibilidades terapêuticas, mesmo em poucas sessões.

Com o surgimento da denominada "terceira força”, a Psicologia Humanista, nos anos 60, a partir da demanda de atendimento a uma sociedade pós-guerra, a Psicologia passa a repensar o modo de compreender as relações com sua clientela, passando a considerar a demanda de uma busca por um bem estar nas situações de vida. Dessa forma, emerge uma outra perspectiva de olhar para a Psicologia, na qual, para além de um olhar psicopatológico, como na Psicanálise, ou uma perspectiva de ajustamento, como na Psicologia de cunho comportamental, redimensiona-se o sujeito humano na potencialidade do encontro terapêutico. Assim, nas palavras de ROGERS (1967)

“Não está proposto que é necessário para a psicoterapia que o terapeuta tenha um diagnóstico preciso do cliente (...) Quanto mais tenho observado terapeutas e quantos mais próximo tenho estado do 
estudo de pesquisas (...), mais sou forçado a concluir que este conhecimento diagnóstico não é necessário à psicoterapia” (p.172,3).

Com isso, a ênfase deixa de ser sobre uma construção pré-definida, seja ela uma escala de um teste psicológico ou uma teoria da personalidade, para se constituir em uma tentativa de se olhar para o cliente, através da compreensão empática. Ou seja, o locus da relação clienteterapeuta, como de qualquer relação que vise o desenvolvimento do indivíduo, passa a ser a atitude do agente facilitador desse desenvolvimento, buscando a atenção e compreensão do modo de ser daquele que é atendido. Porém, novamente esta concepção vai clamar para si o status de conceito, buscando o mesmo rigor metodológico que até então criticava. As tentativas de ROGERS de mesurar as atitudes do terapeuta representam claramente esta tentativa de matematizar, com parâmetros positivistas, a experiência.

Estas e outras correntes, tanto psicológicas, por exemplo, a Psicologia da Gestalt, quanto educativas, como a Pedagogia Filosófica e a Pedagogia Técnico-Científica (FRANCO, 2001) em suas tentativas de analisar historicamente e compreender a cisão entre mente e corpo do homem moderno, vão incorrer muitas vezes, nesta contradição: fornecem críticas ao positivismo e novos elementos para pensar a condição humana, mas requerem, deste mesmo positivismo uma avaliação positiva em termos de meios através dos quais pode-se construir um conhecimento válido, avaliação esta superada, inclusive, pelas ciências mais consolidadas, cuja legitimação se dá cada vez mais no plano da eficácia (FIGUEIREDO, 1995). ASH (1966), ilustra este aspecto, afirmando: “Por que os físicos não podem falar com as estrelas $e$ correntes elétricas, os psicólogos têm, freqüentemente, hesitado em falar com os homens, seus objetos de estudo”(p.5) 
Esta contradição se refletirá claramente no ensino praticado nas universidades, que além de tudo se regula, enquanto instituição, através dos critérios oriundos de um ensino pautado pelo método, bem como pelos fatores econômicos e sociais do contexto no qual está inserido. Além disso, uma outra questão acompanha esta: ao requererem para si o status do conceito, tanto correntes psicológicas quanto educacionais se utilizarão, para isto, de um certo distanciamento entre sujeito e objeto, através da institucionalização de suas idéias, referendando instrumentos teórico-práticos descontextualizados das situações reais de existência.

Percorrendo a literatura, percebe-se que a questão dos movimentos de construção de saber como fenômenos criadores de sentido para a prática em Psicologia é um tema que vem sendo estudado por diversos autores (MORATO, 1999, SCHIMIDT, 1990, FIGUEIREDO, 1995a, BLEGER, 1998, FREIRE, 1987, AMATUZI, 1989, ROGERS, 1978,1985) dada a sua relevância tanto no campo da educação como no da própria Psicologia. No âmbito deste tema, a concepção do que seja uma aprendizagem capaz de fazer com que o educando possa lidar com os acontecimentos de seu cotidiano profissional foi se modificando ao longo do tempo. Tais mudanças ocorreram, até certo ponto, paralelamente às transformações e questionamentos quanto ao lugar da Psicologia, enquanto ciência e profissão, gerando críticas e discussões acerca das divergências de compreensão frente às demandas com as quais se ocupa.

Ao explicitar questionamentos que, se estavam próximos à prática psicológica, percorrem também o próprio campo da educação, estes autores remetem aos profissionais e educadores da Psicologia questões que repercutem no ensino, na prática e na pesquisa em Psicologia. No âmbito desses questionamentos, a questão da formação abrange novas reflexões: que critérios e que concepções podem auxiliar a aprendizagem de formas de atuação que visem este bem estar? Afinal, o que e como deve ser ensinado? Que tipo de prática e de 
conteúdo estamos nos propondo a ensinar e a aprender e com o que ele está comprometido? Que tipo de atuação efetiva o que se propõe a ensinar gera e que conexões existem entre os conteúdos teóricos e a prática? O que se espera deste ensino?

Muitos autores depararam-se com questões semelhantes, realizando críticas e propondo novas formas de compreensão do ensino em Psicologia, buscando uma perspectiva mais coerente tanto com as críticas de muitas teorias psicológicas as questões do conhecimento tal como se apresentam na tradição metafísica, quanto a uma visão de sujeito que considerasse sua incompletude, em sua constante tensão entre previsibilidade e imprevisibilidade, quanto ao contexto em que tanto investigações quanto ensino e prática são realizados.Neste sentido, uma preocupação tem sido a de, de alguma forma, desprender-se do estreitamento ideológico das representações claras e distintas, recuperando a possibilidade de criação, ou seja, abrir espaço para possibilitar o surgimento de novas reflexões..

AMATUZZI (1989) coloca a criação de sentido para a experiência como centro de uma educação e de uma psicoterapia que se proponha a refletir e transformar as ações do cotidiano. Desse modo, tanto a educação quanto a psicoterapia só podem ser pensadas como possíveis de serem apropriadas pelo sujeito através da busca de sentidos para a experiência, o que implica no deparar-se com o novo, recriar os modos de fazer inerentes á prática, no diálogo constante com o outro.

“Também do terapeuta podemos nos perguntar se sua fala é autêntica ou uma expressão secundária. Ela é secundária quando ele (...) apenas põe à disposição do cliente um repertório de conhecimento (...) de qual partes são mecanicamente mobilizadas (...). Será autêntica quando também ela for nova, ainda que a partir de 
conteúdos ou da presença total do cliente (...), quando ele (...) estiver também improvisando (...) por mais experiência que tenha". (AMATUZZI,1989,p.26)

\section{3. Psicologia e ensino de Psicologia: algumas considerações sobre o contexto brasileiro}

Embora este trabalho se produza em um campo de pesquisa no Estado de São Paulo, e ainda, na Universidade de São Paulo, havendo, portanto, várias especificidades relacionadas a um contexto econômico e social particular, pretende-se aqui relacionar alguns aspectos relacionados a questão da América latina e do Brasil enquanto constando de uma determinada história e de um desenrolar de relações econômico-sociais que certamente influenciam a educação e a construção da Psicologia como ciência e profissão. É claro que as especificidades de cada região, inclusive das relações sócio-econômico-sociais entre as diferentes regiões, também influenciarão a educação, incluindo aí o ensino de terceiro grau e a Psicologia. Porém, a análise destas especificidades excederia o objetivo deste trabalho. Pretende-se aqui apenas levantar alguns elementos para a compreensão das referências e concepções presentes no percurso do estabelecimento da Psicologia e do ensino de Psicologia no Brasil em seus conflitos e afinamentos com as possibilidades de reflexão e contextualização acerca das modalidades de prática Psicológica aqui desenvolvidas.

Os primeiros elementos de um pensamento Psicológico no Brasil aparecem no período colonial, difundido nas áreas da Teologia, Moral, Pedagogia, Medicina, Política e Arquitetura, abrangendo de alguma forma a análise ou reflexão sobre os fatos psíquicos (ANTUNES,2001), sendo que a maioria dos autores possuía formação jesuítica e formação acadêmica européia, desempenhando funções religiosas ou políticas. Tanto do ponto de vista 
de uma terapêutica, em que se figura nestes trabalhos o tema da “cura” de emoções, quanto do ponto de vista de uma pedagogia, em que aparecem articulações entre os fatos psíquicos e a educação, considerando-se, como em sermão do Padre Antônio Vieira, que "emoções excedidas são enfermidades”, a perspectiva adotada é de uma educação ou terapêutica que vise o controle e adaptação do indivíduo.

Além da preocupação com a educação e “cura” adaptativa dos indivíduos, registra-se nas idéias da época uma concepção do ócio como um vício, derivando-se dessa idéia a necessidade de condenação e/ou adaptação do indígena. Esta concepção, aliada à de que o clima brasileiro favorece o ócio perdurará até o século XX, influenciando o pensamento psicológico e psiquiátrico brasileiro. No final do período colonial, surgem os primeiros trabalhos sobre psicopatologia, ligados à medicina, e estabelecendo relações desta aos estudos do sistema nervoso, além de surgirem articulações entre sexualidade e loucura. Além disso, aparecem neste período questionamentos sobre o papel da mulher, inclusive abrangendo concepções contrárias à sua completa submissão.

Articulando-se os temas abordados, percebe-se entrelaçamentos das concepções psicológicas da época ao contexto histórico-social brasileiro como colônia de exploração, necessitando de um forte aparelho repressivo e um sólido aparato ideológico para sua manutenção, sendo este sustentado principalmente pela Igreja Católica, para a legitimação da exploração. Para tanto, um papel fundamental foi exercido pela Companhia de Jesus (jesuítas).

Ao mesmo tempo, percebe-se nas obras da época aspectos e concepções originais, com o prenúncio da psicoterapia, em estudos sobre a educação, em relações entre prática médica e saber psicológico, entre outros (ANTUNES, 2001) Assim, as idéias psicológicas da época oscilavam entre articulações e confrontos com os interesses metropolitanos, refletindo contradições quanto à função social dos estudos psicológicos. Como afirma ANTUNES 
(2001) "as necessidades impostas pela realidade exigiam soluções que ao mesmo tempo buscavam a manutenção da ordem estabelecida, confrontos com esta ordem $e$ impulsionadoras do real para o futuro”(p 42).

Com as transformações sociais que foram possibilitando a mudança do Brasil de colônia para império, o pensamento psicológico foi se vinculando às instituições que então foram sendo criadas, mas ainda atrelado a outras áreas do conhecimento, principalmente na educação e na medicina. Isso, a partir da transferência da corte portuguesa para o Brasil, gerando a necessidade de quadros para a repressão e administração governamental, implicando em uma preocupação com a educação, e na criação de cursos superiores para formação, mas em que era rara a produção de conhecimento. Houve, também, o desenvolvimento do ensino secundário, em iniciativa privada, em especial da Igreja Católica. A exceção foi o Colégio Pedro II, no Rio de Janeiro, universalista e enciclopédico, sendo também elitista e de finalidade modelar.

O pensamento brasileiro, inclusive educacional, no século XIX, apresentou-se com profunda influência européia principalmente liberalista e positivista, havendo também influencias do tomismo e do empirismo, alem do espiritualismo francês e do idealismo alemão. Essas idéias têm influência sobre o pensamento psicológico, constituindo-se como conteúdos relacionados a questões de natureza psicológica, transmitidos, sobretudo em obras filosóficas então difundidas. Teólogos, professores e médicos são seus autores e tendem a considerar a psicologia como parte da metafísica, tendo como objeto de estudo a "alma”, o “espírito” ou o "eu”. Idéias relacionadas aos fundamentos da vida psíquica, como identidade, consciência, entre outras, e fenômenos psíquicos, como motricidade, percepção, etc, aparecem em obras psicológicas e pedagógicas das primeiras décadas do século XX. 
Assim, a preocupação pedagógica do período desenvolve o pensamento psicológico nas inter-relações entre fenômenos psicológicos e métodos de ensino, no conhecimento sobre o educando e na formação do educador, na educação das faculdades psíquicas e aprendizagem e no uso de castigo e recompensa como instrumento educativo. Neste sentido, percebe-se uma acepção da Psicologia como um campo do saber que pode servir de instrumento a uma normatização no campo educacional.

A partir da Primeira República, o campo da saúde é ampliado como área de atuação do saber psicológico. Data desta época o início da formação de uma assistência em saúde mental, em que o conhecimento psicológico é compreendido como instrumento disponível às práticas de higienização como terapêutica ao comportamento desviante, concebidas como favorecedoras do desenvolvimento social (ANTUNES,2001) juntamente às praticas educativas como meio de profilaxia, na busca de "um povo forte mental e fisicamente" (ANTUNES, 2001).

Nesse contexto, destacam-se alguns autores que buscaram outras perspectivas para a solução das questões educacionais brasileiras. Entre eles, está Manuel Bonfim, que buscava causas sócio-históricas no desenvolvimento educativo, sendo o precursor da difusão da educação como condição de liberdade, relacionando-a dessa forma ao favorecimento da cidadania e não apenas a uma função no desenvolvimento econômico, Alem dele, Helena Antipoff, que estabeleceu relações entre a aprendizagem e meio social, alem de ser precursora da psicologia de campo. Também Ulisses Pernambucano, na diretoria de uma das primeiras instituições psiquiátricas no Brasil, trouxe contribuições visando novas formas de compreensão das questões psicológicas, sendo o precursor da anti-psiquiatria, através do movimento psiquiátrico do Recife, embora com pouca divulgação. Sua concepção de doença 
mental como situação existencial, visando o favorecimento da cidadania, constituía um avanço nas concepções sobre a psicopatologia do período.

A partir da segunda década do século 20, o ensino sistemático de psicologia inicia-se nas escolas normais, sendo instituída a disciplina de Psicologia em 1928, por decreto, nessas escolas. Os conteúdos ministrados afinavam-se às idéias higienistas e disciplinares correntes na época.

Assim, a Psicologia se desenvolve e se difunde num papel autoritário de repressão e controle social do desviante e do trabalho, e na educação como modelagem, com um corpo de técnicas de condicionamento, classificação, seleção, psicometria, etc. Ao mesmo tempo, em instituições brasileiras surgem algumas iniciativas de outras compreensões, tanto da Psicologia quanto de seu papel social, que apontam para uma contextualização social da prática e possibilitam releituras teórico-praticas.

Algumas destas concepções estavam também presentes ao longo da Era Vargas, sendo que começam a constituir novos campos de utilização dos saberes psicológicos. Assim, no movimento histórico que conduziu Getúlio Vargas à Presidência da República, em 1930, apresentavam-se concepções vinculadas ao saneamento governamental e à busca de eficiência administrativa. Além disso, emergiam necessidades relacionadas à busca de mão de obra para o mercado de trabalho, em decorrência da expansão industrial e das transformações econômicas, sociais e políticas. Assim, a Psicologia é chamada a selecionar e recrutar os trabalhadores para diferentes cargos, sendo também utilizada para orientação vocacional e nas escolas. Visando a seleção e adaptação ao trabalho, constituem-se os então chamados psicotécnicos (MANCEBO, 1999; ANTUNES, 2001). É nesta época também que a Psicologia passa a afigurar no currículo dos cursos de Pedagogia e Filosofia. Segundo FILHO (1969: 2004) 
"O movimento de industrialização fez deslocar grandes grupos da população rural para as cidades, gerando graves problemas de ajustamento; por outro lado, elevou a demanda de ensino por toda parte (...) vindo a sentir delicadas questões de organização e administração. Os remédios da Psicologia passaram a ser reclamados...” (p.109).

Percebe-se, assim, claramente, a concepção e a construção de uma função social do saber psicológico vinculado ao ajustamento e organização do indivíduo. Esta construção histórica da psicologia no Brasil vincula-se às próprias questões sócias da posição do Brasil no nível geopolítico - sendo sua origem histórica a de colônia, liga-se aos países desenvolvidos pelo atraso, necessitando de um ajuste constante para caminhar segundo as concepções e relações que norteiam o desenvolvimento social nos países desenvolvidos. Por outro lado, vincula-se ao desenvolvimento do capitalismo, em sua dimensão organizacional da sociedade.

No Brasil, a esta questão vem somar-se um outro problema: o fator de este sujeito nunca ter sido, aqui, plenamente estabelecido (FIGUEIREDO, 1995b). Tem-se, ao invés disso, um país dividido entre um modo de subjetivação tradicional, holístico e hierárquico, formador de pessoas (personae, máscaras, subjetividades atadas aos lugares que ocupam em uma rede estreita de relações e guardam certa liberdade diante da consciência reflexiva do sujeito moderno) e (meros) indivíduos (que gozam de uma discutível independência de vínculos com a tradição, ficam reduzidos a uma condição de objetos submetidos ao uso e ao controle de sujeitos ou, no caso brasileiro, pessoas) (DA MATTA apud FIGUEIREDO, 1995b). É esta questão que se faz presente, por exemplo, nas concepções acerca da miscigenação, e que geraram as práticas higienistas da República Velha e da Era Vargas. 
Haveria, no Brasil, constantes transições nos espaços em que ora reinam as pessoas, ora os meros indivíduos, com conjuntos de valores e espaços bem marcados. Neste sentido, num país com um capitalismo dependente e periférico, e até o século XIX, escravocrata, as idéias liberais, tecnocratas e românticas desenvolvidas ao mesmo tempo em que se constituía o sujeito moderno europeu, no século XVII, perderiam o sentido sem, exatamente, aquilo que lhes dava assento: o sujeito epistêmico. Assim, teorias e práticas desenvolvidas em um contexto europeu e não repensadas chegam aqui, como denominou FIGUEIREDO (1995b), fora de lugar. Como diz o autor:

Que essas teorias nada tenham a ver com nossas experiências é de somenos importância desde que nos façam falar como os sujeitos falam (...) as falas tornam-se ingredientes para as poses e as idéias deixam de ser aparelhos para pensar convertendo-se em distintivos sociais (p.38, grifos do autor)

Ainda nesta época, percebe-se a questão higienista e normatizadora na educação, que perdurou ainda após o período Vargas. Esta questão aparece em texto de Annita de Castilho e Marcondes Cabral, figura proeminente da Psicologia na época, publicado em 1950. Nele, escreve uma apresentação para a publicação nos Estados Unidos, descrevendo o Brasil como sendo constituído de três raças - a negra, a indígena e a ariana -, das quais apenas a raça ariana seria constituída por pessoas de criatividade, e acrescentando a questão da miscigenação como um problema que produziria indivíduos desviantes (autistas ou ciclotímicos) (CABRAL, 1950: 2004). Assim, necessitava de práticas higienistas, tanto no campo profilático (via educação), quanto no campo terapêutico (via higiene mental), para seu desenvolvimento. 
MOFFATT (1986) aponta para as vicissitudes decorrentes da adoção de teorias e práticas na ausência de reflexão sobre o contexto histórico-social da América Latina, ressaltando que a relação de colonização implica vicissitudes para a produção de conhecimento na colônia, já que os instrumentos científicos, assim como os produtos materiais e industrializados, acabam por ser importados dos colonizadores. Assim, dirige-se a uma "hiperinformação teórica”, que, para o autor, pode ser lida, inclusive, como sintoma de uma fuga da realidade. Independentemente desta interpretação, se favorece a possibilidade de uma desvinculação teórico-prática, ou da aplicação de práticas menos pertinentes ao contexto em que atuam, podendo resultar em problemas na efetividade das abordagens adotadas, como os que SANTANA (2001) refere na Rede Pública brasileira, na qual muitas vezes os dispositivos teórico-práticos se mostram insuficientes para referendar uma prática psicológica que lidará com problemas advindos de precárias condições sociais.

Neste sentido, não apenas carregamos uma desconsideração da experiência típica da tradição epistêmica moderna, como nos encontramos com as dificuldades de um repensar comprometido com um contexto social no qual as idéias e palavras estão na condição de adorno. Assim, as práticas, tanto no âmbito da Psicologia como no âmbito da educação, muitas vezes já "vêm prontas” tanto em sua institucionalização histórica quanto em sua massificação colonizada. Este fato pode ser observado tanto em algumas práticas terapêuticas, quanto em algumas abordagens educacionais, como a Escola Nova e a Teoria da Carência Cultural (PATTO, 1984) tornando ainda mais difícil sua articulação com o contexto e com a experiência.

Dessa forma, o ensino de psicologia estará permeado pela questão da conceitualização como técnica, pela questão da importação de saberes e pela questão da tecnização do ensino superior como política governamental. Isso, em uma área cujo cerne são as relações humanas e 
o trânsito de experiências, ao menos em tentativas de uma prática psicológica que desconstruam a idéia de civilização plena. Pode-se relatar, a título de ilustração, uma experiência de estágio realizada em um curso de graduação em Psicologia em uma universidade brasileira (GODOY, 1985): a instituição estabelece um tempo pré-determinado de atendimento, nesse caso, 12 sessões, e o "perfil” de clientes que os alunos estariam “preparados” para atender de acordo com a bagagem teórica ministrada até o quarto ano de curso - nesse caso, pessoas de mais de 15 anos, linguagem “adequada à idade”, queixa própria de sua faixa etária, ausência de “desvios de personalidade e/ou inteligência” (p.89)- e o modo de organização da psicoterapia: o atendimento deve ser sempre na mesma sala, deve haver 12 sessões de 50 minutos uma vez por semana, e pagamento.

A instituição estabelece que se explique o trabalho para o cliente, a necessidade de este “colaborar” contando tudo o que possa ser útil e pensando no que o terapeuta lhe colocar, e que duas faltas consecutivas, sem aviso, é considerado desistência, devido à "instabilidade registrada quanto à presença dos clientes”. O supervisor explica aos alunos que o trabalho a ser desenvolvido seria Psicoterapia Breve de esclarecimento com metodologia de compreensão psicanalítica. Explicita, inclusive, que a psicoterapia breve compreende 12 sessões e o cliente senta-se frente a frente com o terapeuta, enquanto na psicanálise o prazo é indeterminado e o cliente deita-se no divã, e que os alunos não podem ir para o atendimento sem supervisão, já que estes, como terapeutas, partirão da queixa manifesta para enriquecê-la com aspectos latentes, discutidos em supervisão, em que também se elaborará um plano de abordagem individualizado com estabelecimento do foco, de acordo com a teoria de FIORINI (1981, apud. GODOY, 1985) e cujas orientações serão dadas pelos “tipos de intervenção verbal do psicoterapeuta” segundo FIORINI (ibid.), que incluem orientações diretas e indiretas ao cliente e atitudes esperadas do psicoterapeuta. Há uma triagem na qual clientes que não se 
adequam ao perfil são encaminhados, e duas listas de espera: uma para triagem e outra para atendimentos. Do grupo de 10 alunos, dois atendem em psicoterapia e 8 fazem as triagens.

Esse relato ilustra como o distanciamento do contexto de relação humana, na qual o inesperado é fator predominante, na qual as possibilidades de desvelamento da alteridade e de recriação do encontro, cerne da atitude clínica, emergem e possibilitam a ressignificação de sentidos, é completamente cerceado pelo pré-estabelecimento de como este encontro deve ocorrer. Esta prática engessada, na qual a aplicação dos conceitos teóricos assume até mesmo a forma concreta da relação terapêutica, que já nasce destituída de muitas possibilidades de matização que os agentes mais diretos do processo - cliente e estagiário - poderiam dar a ela, mostra sua conseqüências em alguns problemas apontados na própria descrição de GODOY (1985).

Para apontar algumas conseqüências desta padronização, se ressaltam dois problemas. O primeiro é que os clientes não ficam - o índice de desistência da terapia é altíssimo; ao mesmo tempo, não há clientes com perfil adequado para todos, então muitos alunos ficam sem atender e muitos clientes ficam sem atendimento.

Assim, uma das conseqüências mais óbvias, mas por isso mesmo, mais difíceis de se vislumbrar da excessiva metodologização no campo humano, e mais especificamente, no terapêutico, é o fato de que a prática terapêutica, oprimida por regras que pode, inclusive, ter perdido sua pertinência e utilidade, pode simplesmente não ocorrer... O distanciamento entre as concepções formuladoras de uma prática e as situações cotidianas concretas é tratado na Educação, a partir do estudo das causas do Fracasso Escolar (PATTO, 1984, SOUZA, 1997). Esta mesma situação de uma prática que não se efetiva no campo educacional se vê apresentada no encontro terapêutico, a partir das tentativas de "jogos de encaixe” irrefletidos, 
que podem estar com um problema fora do âmbito teórico, mas no nível de sua articulação com a experiência.

Como conseqüência, outra questão que se apresenta é a das possibilidades e limites de uma aprendizagem clínica neste contexto. Vários autores discutiram a formação em Psicologia a partir da aproximação entre psicoterapia e aprendizagem proporcionada por estes questionamentos próximos aos dois campos. Algumas questões propostas por EISENLOHR (1997) podem elucidar esta preocupação:

“Como é que nos formamos? De que modo a variedade de abordagens práticas e teóricas, que nos ensinam ao longo do curso, vão compor um quadro significativo que se transformará em substrato para a atuação profissional? (...) De que modo nós (...) podemos de fato contribuir para esse desenvolvimento que, a partir do contato conosco, leva-os à profissionalização?” (p.3).

\section{Psicologia clínica e experiência: em busca de pesquisa-prática-aprendizagem contextualizadas}

No duplo movimento de construção de sistemas teóricos que possibilitassem instrumentalização para reflexões pertinentes na psicologia clínica e de institucionalização e engessamento dos conceitos constituídos neste contexto, há retomadas, ao longo do percurso de diferentes abordagens da Psicologia, da necessidade de contextualização e reinvenção da prática Psicológica. 
WINNICOTT (1984), por exemplo, argumenta e fundamenta a possibilidade de se trabalhar uma questão em poucas consultas terapêuticas, em um contexto histórico em que a institucionalização da análise psicanalítica já se encontrava efetivada. Na perspectiva do autor, quando o ambiente no qual o paciente está inserido é bom, pode-se trabalhar em um número mais reduzido de sessões, para a abordagem de questões mais pontuais. Procura, assim, utilizar-se do trabalho terapêutico de forma a torná-lo pertinente e efetivo ao contexto em que atua.

FOUCAULT (2001) E GOFFMAN (1996) contribuem para essa discussão demonstrando os mecanismos pelos quais as “instituições totais” destroem o sentimento de identidade dos sujeitos. Dessa forma, trazem a possibilidade de relativizar culturalmente técnicas de tratamento e reorientá-las para que estejam contextualizadas aos aspectos culturais de cada grupo social.

BASAGLIA (1982), analisando as ideologias subjacentes à prática psiquiátrica, desconstrói a depuração científica dos pressupostos psiquiátricos desvelando suas relações com os aspectos políticos, econômicos e sociais.

Na América Latina, frutos da reflexão acerca de modos de articulação de concepções teóricas e metodologia de trabalho se colocam em possibilidades para atentar a contextos específicos e ao movimento de engessamento próprio da institucionalização que permeia a modernidade. FANON (apud MOFFATT, 1986) relaciona o desenvolvimento da psiquiatria e da Psicologia no Terceiro Mundo à ideologia colonialista européia, recontextualizando socialmente as práticas psicológicas.

Segundo MOFFATT (1986) a “cultura psicanalítica” de Buenos Aires estava adaptada para as transações da burguesia, na qual, inclusive, não cabia "a revisão da questão sexual e dos impulsos inconscientes, própria da psicanálise” (p. 160). Ressalvando as especificidades 
pertinentes a cada país, podemos articular esta experiência à experiência brasileira, através da condição comum de colonizados de ambos os países. O pioneiro na busca de uma recontextualização teórico-prática na América Latina foi Pichon-Riviére, abrindo “o caminho que conduzia do divã para a rua, para a comunidade, e seu criador usou a técnica psicanalítica para resolver os problemas de nossa realidade quotidiana e comunitária” (MOFFATT, 1986, p.160).

Estas novas formas de atendimento terapêutico ancoram-se na preocupação de se comprometer com um olhar para aquele que sofre, e, portanto, de se buscar encaminhamentos para sua demanda específica. MOFFAT (1985) já demonstra essa preocupação, ao criticar a estrutura de funcionamento da psicoterapia, atentando para o fato de que esta foi pensada e constituída para o contexto sócio-cultural pequeno-burguês da Europa do final do século XIX e início do século XX. É também neste sentido que MOFFATT procurará articular uma possibilidade clínica par o atual momento da modernidade, dialogando com o contexto e possibilitando uma construção dialógica de percepções da realidade. O próprio autor irá então relatar experiências de busca de uma abordagem terapêutica ancorada ao seu contexto, reinterpretada "do ponto de vista de um Terceiro Mundo em processo de mudança e dentro dos moldes culturais crioulos” (p. 168), como a da Comunidade Popular Peña Carlos Gardel. Assim, um olhar que contemple o contexto específico daquele que explicita uma demanda considera uma recriação, um metamorfosear-se na busca de formas possam responder de maneira mais habilidosa a este.

SZYMANSKI (2001, 2004) procura articular, neste sentido, psicologia e educação, através de uma experiência de pesquisa e intervenção participativa em uma favela paulistana. Assim, ao atender uma parcela da população na qual as vivências diferem daquilo que é veiculado pela cultura dominante, busca partir da própria experiência da clientela atendida, 
resgatando articulações e recursos negados. Nesta perspectiva, a referenciação a partir do resgate da contextualização na experiência proposto por FREIRE (1989) possibilita também a articulação teórico-prática a partir da experiência de estagiários atuantes nesta prática.

VAISBERG (2003) aponta este questionamento do ponto de vista da psicanálise. Para ela, a consolidação do modus operandi psicanalítico tradicional como forma de intervenção para a população brasileira atual está descontextualizado:

“A clínica contemporânea difere daquela diante da qual foi possível edificar a psicanálise enquanto método psicológico de estudo do homem, enquanto terapêutica individual de pacientes diagnosticados como neuróticos e enquanto conjunto específico de teorias daí oriundas” (p. 95).

Por um lado, tem-se uma técnica que zela pela manutenção do consultório ou sala específica nas instituições, como espaço “neutro” como setting para o atendimento clínico, a preferência por um trabalho cuja regularidade deve se efetivar em, no mínimo, uma vez por semana, e cujo pagamento deve estar estipulado em um determinado valor, a instituição da psicanálise como uma forma específica de atendimento individual, o uso da teorização estritamente psicopatológica na abordagem psicanalítica, ou a centralização excessiva nas atitudes, freqüentemente padronizadas, do terapeuta na Abordagem Centrada na Pessoa. Por outro lado, tem-se o sofrimento humano em hospitais, escolas, nos mais diversos lugares e das mais diversas formas, cuja população, muitas vezes, tem dificuldades de todo tipo para chegar ao consultório, necessitando, muitas vezes, se adequar a um sistema já dado para conseguir atendimento psicológico. 
Além disso, encaminham-se indagações acerca da eventual "produção social e cultural de novas formas de padecimento" (VAISBERG, 2003, p.95). Como afirma a autora, "hoje, a ajuda psicológica é buscada ou recomendada para os mais diversos modos de sofrimento humano, que vão desde variadas situações de doença física até radicais condições de precariedade social.” (ibid., p. 96) e “ se mantém freqüentemente em um nível de abstração que nos distancia do que é quotidianamente vivido na clínica” (ibid., p. 96).

A partir de solicitações de instituições que geraram o questionamento destes paradigmas, inaplicáveis às condições dos contextos encontrados, VAISBERG (2003) propõe novas formas de intervenção, através de oficinas terapêuticas, como forma de possibilitar uma intervenção clínica mais contextualizada. Assim, relata e fundamenta

"uma prática psicanalítica que parte, coerentemente, do pressuposto segundo o qual não existem limites para a compreensibilidade das condutas humanas, mas que não opera clinicamente por meio de intervenções interpretativas e sim pela via da sustentação do encontro terapêutico” (p.95),

alegando que “quando um fazer clínico se torna próprio, no sentido forte da palavra, o fazer clínico pode se dar de modo flexível e inventivo, de sorte que novos desafios podem receber respostas criativas $e$, ao mesmo tempo, fundamentadas de modo rigoroso, sob os pontos de vista teórico e metodológico” (p.97). 
Esta perspectiva clínica abre, também, espaço para pensar a formação na psicologia clínica, já que ressalta a importância da apropriação de um saber para sua constante recontextualização. Essa apropriação resgata, no campo da formação nestas práticas, a importância da articulação entre reflexão teórica e experiência vivida, abrindo possibilidades de questionamento em relação à formação.

Pensando na psicologia brasileira, uma das formas de flexibilização do instituído que se apresentou com grandes repercussões foi o Plantão Psicológico. Embora oriundo do pensamento humanista de Carl Rogers, apresentando, portanto, também, suas contradições em relação ao pensamento metafísico, esta se constituiu no Brasil justamente na hora da legitimação da Psicologia como profissão, questionando alguns dos conceitos institucionalizados carregados pela psicologia. Embora a idéia de encontros significativos não fosse nova, sendo utilizada pela própria psicanálise, em Winnicott e Bion, de uma certa forma foi-se institucionalizando historicamente um certo padrão de atendimento psicológico. Assim, a proposta de plantão, de uma certa flexibilização, na qual o horizonte é o clareamento de uma demanda, se apresenta, de certa forma, como revolucionária.

No Brasil, esta prática nasceu no IPUSP através de Raquel Rosemberg e do próprio Carl Rogers (MORATO, 1999). Aqui, surgem novas possíveis formas de atendimento, além das psicoterapias por tempo prolongado, como a psicoterapia breve, os grupos de encontro, as supervisões de apoio psicológico e o plantão psicológico. Ao longo do seu desenvolvimento, contudo as próprias demandas que chegaram à clínica psicológica levantaram a necessidade de desconstrução e reinvenção do Plantão Psicológico.

Esta prática, embora tenha sido cada vez mais difundida, muitas vezes também foi assimilada em termos de um novo padrão. Assim também, o ensino, que buscava ser exatamente referenciado na experiência do contato clínico, no diálogo da intersubjetividade, 
tendem e ensaiam, algumas vezes, para uma padronização, com o risco da redução da expressão diacrítica do encontro terapêutico a conceitos preestabelecidos. Dessa forma, MORATO (1999) irá rearticular a perspectiva norteadora do Plantão, a partir do diálogo das experiências com a fenomenologia existencial, em especial Martin Heidegger e, mais recentemente, Merleau-Ponty, com a contribuição da perspectiva fenomenológica do Aconselhamento Psicológico engendrada por Gendlin em suas primeiras articulações acerca da clínica e da experiência com a fenomenologia. Desta forma, as demandas que começaram a chegar por atendimento em instituições possibilitaram olhar de novo, favorecendo uma nova descontrução e reinvenção da perspectiva terapêutica que havia norteado o Plantão Psicológico.

Juntamente com estas questões há a consideração da importância, na atuação profissional, da possibilidade de um repensar e transformar a prática de acordo com a demanda e as possibilidades do contexto de atuação (MORATO, 1999). Da mesma forma, uma formação em psicologia que contemple esta forma de atuação se realizará a partir da prática e de um espaço de reflexão para ela, ao invés da simples transmissão de informações. Assim, MORATO (1999) confirma que

"(...) no circuito da informação, a palavra está restrita àqueles que detêm o conhecimento instituído. Ao mesmo tempo, surge a figura do leigo, que está autorizado a ouvir, mas não a falar. Se quisermos tomar a experiência como matéria prima na formação (...) faz-se necessário restituir o valor da narrativa e da existência de uma comunidade democrática de ouvintes e falantes como condição para uma proposta educacional compatível (...) e 
explicitar um sentido de aprendizagem no qual a experiência seja contemplada." (p.125)

A busca de uma recontextualização teórico-prática expressa por estes autores não significa um abandono da fundamentação já construída nos diversos campos da ciência Psicológica. Antes, significa a manutenção de uma abertura para a pluralidade das emergências e especificidades de cada contexto de atuação e das transformações históricas sociais e culturais neles ocorridas. Esta necessidade de reflexão teórica e prática a partir da experiência clínica efetivamente vivida transcorreu também no desenvolvimento do Aconselhamento Psicológico no IPUSP, como anteriormente exposto, e passou por transformações e reflexões que contextualizam o campo desta pesquisa, sendo este percurso abordado a seguir.

\subsection{Atenção Psicológica em Instituições e Plantão Psicológico: um percurso caminhando em direção a outras perspectivas}

No caso do Serviço de Aconselhamento Psicológico do IPUSP, a partir da década de 90, algumas demandas se apresentaram de forma nova: a demanda por atendimento começava a vir não mais de uma pessoa que procurava ajuda, mas de instituições que procuravam auxílio para seus participantes. Dessa forma, foi se constituindo um modo de se fazer e se refletir sobre a prática a cada experiência dentro destas instituições.

Neste sentido, a fenomenologia mostrou-se como uma perspectiva pertinente para a compreensão destas experiências e para a reestruturação das abordagens teórico-práticas adotadas. Ao compreender o homem como existindo em situação e como cuidando de ser, no sentido de responder às situações que se lhe apresentam, a abordagem fenomenológica ancora 
o modo pelo qual as inserções de serviços em instituição se dão. A saber, afastando-se da aplicabilidade técnica a serviço de um ajustamento das subjetividades ao discurso institucional dominante. E também atenta a um possível ajustamento dos sujeitos em quadros referenciais teóricos apriorísticos de vertentes românticas (enaltação burguesa do indivíduo autônomo e livre) ou disciplinares (aniquilação do sujeito através de mecanismos sociais de ilusão da singularidade).

A perspectiva fenomenológica possibilita, nesse sentido, um redimensionamento das articulações entre sujeito e instituição, entre o sujeito e seu contexto, através de uma reorientação epistemológica da fala. Nessa perspectiva,

“quem ouve verdadeiramente não escuta sons esparsos, sem conexão; percebe o ruído pesado da chuva, o prolongado cicio do vento, etc. Perceber desta maneira é compreender, como se compreende o outro escutando-o e como escuta ou ausculta com as mãos, aquele que nada vê. Mais do que a minha fala, a escuta de quem me ouve assinala a ocorrência da compreensão” (NUNES, 1999, p.

Deste modo, é possível o dimensionamento de uma diacriticidade tanto nas relações institucionais quanto nas possibilidades do conhecer, implicadas tanto na pesquisa quanto na formação. Através da concepção de conhecer como fusão para dar nascimento (TELLES, 1987 apud MORATO,1999), ir junto, que podemos entender as peculiaridades de cada instituição, redimensionando o lugar da teoria como uma ação de teorizar implicada numa práxis contextualizada. 
Assim, constituíram-se os primeiros trabalhos desenvolvidos em instituições no contexto desta abordagem. A partir da especificidade de demandas oriundas de diferentes contextos e da reorientação teórico-prática daí advinda, é fundado o Laboratório de Estudos e Prática em Psicologia Fenomenológica Existencial (LEFE), no qual se buscará articular as modalidades de prática clínica de atendimento em diferentes instituições, a formação em psicologia e a pesquisa a partir das intervenções institucionais. Para uma maior contextualização, estas experiências serão brevemente relatadas a seguir.

Dessa forma, os trabalhos de Atenção Psicológica em Instituições partem da cartografia, que se coloca como método com dupla função: ao mesmo tempo em que detecta a paisagem, abre vias de passagem através dela (MORATO, 1999). A cartografia é uma forma de investigação. Mas também de construção de caminhos. Ela se faz ao mesmo tempo que o território: vislumbrando o território, ela o transforma através dos rastros e caminhos possíveis nele, deixados pelo cartógrafo.

Em uma experiência de Plantão Psicológico na escola (MAFOHUD, 1999), por exemplo, o trabalho era realizado em função do aluno e os pedidos da instituição em relação a este eram reconfigurados para garantir um olhar para o aluno como pessoa. O sentido daquele trabalho era pensado como sendo dado não pela instituição em que se trabalhava, mas pela possibilidade de redimensionamento a partir da articulação de sentido, carregado consigo por aqueles que ali habitem.

Em um hospital psiquiátrico (CAUTELLA, 1999, 2001), esta mesma diretriz se apresentava como uma forma de otimizar ao máximo o tempo de que os psicólogos dispunham para favorecer ao indivíduo as condições necessárias para seu desenvolvimento, além de levar em conta a doença mental como sendo uma "patologia da liberdade”, no sentido de uma dificuldade de elaborar possibilidades para um poder-ser. Assim, a prática adotada, coerente a 
essa concepção, é a da psicoterapia como um resgate do indivíduo de um vazio paralisante para a plenitude de sua cidadania.

Foi realizada também, uma sistematização do serviço de Plantão Psicológico que, dentro do hospital psiquiátrico assume caráter terapêutico, já que estabelece coordenadas fixas que servem à reorganização psíquica, e que possibilita a existência de um espaço permanente com o qual se pode contar e que por isso é aliviador de angústias. Assim CAUTELLA (1999) relata uma experiência de atendimento, através do Plantão Psicológico, de uma interna com diagnóstico de esquizofrenia residual, cujas formas de atendimento sistemático presentes no hospital não contemplavam.

“...certo dia, R.F.A. entrou no consultório onde era realizado o plantão psicológico. Sentou-se e permaneceu em silêncio (...), deixava transparecer um certo incômodo. Perguntei o que havia acontecido. Com muito esforço e com poucas palavras, R.F. A. apontou para os pés descalços e contou que havia perdido seus sapatos. (...) começamos um exaustivo trabalho visando relembrar quando fora a última vez que os havia visto. Apontei a importância de cuidar daquilo que lhe pertence. Saímos à procura dos sapatos (...) até os encontrarmos abandonados sob uma cadeira. R.F.A. calçou-os, sorriu e voltou para o seu mundo de alheamento. Porém, até o fim da internação, toda vez que me via (...) apontava para os pés e sorria 
(...) Nesse breve encontro foi resgatado, sem dúvida, mais que um par de sapato. Estava implícito (...) o resgate da individualidade de R.F.A.(...). Parece ser pouco, porém é muito se levarmos em conta o quadro patológico de R.F.A.”

Já as experiências de Supervisão de Apoio Psicológico eram concebidas como espaços/encontros com a função de possibilitar que experiências fossem compartilhadas e interrogações pudessem ser formuladas ou reformuladas na formação de profissionais de saúde e educação. Ocasião para elaborar a experiência vivida na prática de um ofício, criando aberturas para a compreensão do fazer profissional e sua inserção em um contexto mais amplo. Assim, as primeiras experiências em Supervisão de Apoio Psicológico deram-se na formação de profissionais de saúde e educação: educadores de rua, técnicos/educadores de projetos voltados à criança e ao adolescente, educadores em psicologia, etc.

No desenrolar do atendimento a diferentes demandas, constantes rearticulações se fizeram presentes. Assim, visando contextualizar a investigação pretendida neste trabalho, torna-se pertinente relatar algumas das discussões trazidas atualmente, nos projetos de Atenção Psicológica em Instituições realizados pelo laboratório de Estudos e Prática em Psicologia Fenomenológica Existencial (LEFE), a partir dos quais surgem essas novas rearticulações de prática contextualizada. É também pertinente relatar sucintamente as experiências de Plantão Psicológico que os sujeitos da pesquisa abordaram em seus relatos.

Vale a pena ressaltar que o serviço conta com uma abordagem fenomenológica em práticas clínicas, compreendendo como clínica seu sentido etimológico, no qual "clínica" origina-se do latim e significa "inclinar-se sobre" como cuidado e atenção a um fenômeno que se desvela. Psicologia clínica nesta concepção seria este inclinar-se, o cuidado ao outro. Com 
essa abordagem entende-se que não se busca um campo de observação "limpo" e isento da presença daqueles que nele intervém e sim que se leva em conta essa presença e sua atuação como modificadora das relações, propiciadora de exclusão/aparição de diversos fenômenos, inclusos na dinâmica institucional, uma vez que presentes em seu cotidiano.

A partir deste contexto, o Plantão Psicológico por um lado transcende a área clínica para tangenciar outras áreas da psicologia (a psicologia institucional, a psicologia social e outras), e por outro no próprio âmbito clínico reconfigura as concepções da prática clínica tradicional. O trabalho nas instituições aponta a necessidade de se voltar o atendimento não só para os aspectos individuais e doentes do cliente, mas ao contrário devem estar voltados para a real necessidade da população em termos de promoção da saúde. Percebe-se que se busca uma desconstrução voltada para o social, porém, esta nova clínica não deve colocar-se em oposição à clínica individual. Deve-se, contudo, abarcar os elementos desta com modificações e recontextualizações. Incluindo-se aí aspectos não previstos.

O Plantão Psicológico caracterizou-se como uma modalidade da psicologia clínica, ou seja, a disposição ao outro que procura ajuda para um atendimento clínico entretanto sem o enquadre prévio tradicional, ou seja, espaço e tempo para as sessões pré-definidos, mas que terá início e fim com uma escuta clínica. A implantação do serviço inicia-se a partir do reconhecimento da demanda implícita nos pedidos formais realizados ao LEFE.

Neste sentido, o Plantão também transformou-se em cada instituição, buscando novas formas de garantir um espaço de reflexão do subjetivo, abrindo-se para atendimentos em locais abertos, conversas em grupo, palestras que transformavam-se em atendimentos em grupo, atendimentos conjuntos à comunidade que procurava os serviços institucionais, etc. A partir desta concepção de Plantão, a concepção de setting também se modificou. Outras formas de ajuda terapêutica além do atendimento individual foram construídas, através de 
respostas habilidosas às demandas que foram surgindo, ainda sim, cabendo na denominação de Plantão Psicológico, pois este não era compreendido como um modelo rígido e fixo de relação terapêutica, mas como um modo de atenção psicológica rigoroso que ganhava corpo á medida que se singularizava em cada contexto. Atenta-se, portanto, a uma relação com o conhecimento e com a formação de profissionais, a partir de uma perspectiva clínica que contemple os imprevistos que a alteridade pode revelar, abrindo-se para a multiplicidade do espaço intersubjetivo.

Alguns norteadores da prática de atenção psicológica eram comuns a todos projetos, como a possibilidade de circulação dos plantonistas-psicólogos pelos ambientes da instituição, o estabelecimento de uma constância temporal para facilitar a organização desse serviço dentro do cotidiano institucional, ocorrendo com a definição de um dia da semana e um período de funcionamento especificados a partir do que a cartografia revelou como mais propícios para cada contexto. Não havia obrigatoriedade de atendimentos, nem números definidos de atendimentos. Esses norteadores visavam um inter-jogo do laboratório com a instituição demandante, na dinâmica institucional estabelecida, sem que a modalidade clínica reduzisse a um modelo de técnica. A não fixação em um espaço físico a priori possibilitava que a questão do sofrimento, que demandava uma atenção, não ficasse restrita a um único lugar na instituição, podendo se remeter a todos atores institucionais e a todas as hierarquias. A constância temporal facilitava a inserção do projeto no organograma institucional de suas atividades, para não gerar conflito de atividades, e também para que os autores organizassemse para utilizá-lo e confiassem na sua estabilidade ao longo do tempo para apresentarem as suas queixas. Essas “possibilidades” e “facilitações” evocadas por essa postura inicial só se concretizavam efetivamente, entretanto, na relação interpessoal com os plantonistas, na 
medida em que as dúvidas e questionamentos sobre o sentido de uma "atenção psicológica" naquele contexto foram comunicadas.

Assim, desenvolveu-se um contexto de pesquisa e intervenção participativa, onde a prática do Plantão possibilita refletir acerca das concepções clínicas e conhecer este novo contexto de atuação. Da mesma forma, na medida em que se oferecem estágios extracurriculares a alunos de graduação trabalhando no projeto, abre-se a possibilidade de formação no âmbito dessas práticas clínicas em instituições. Considerando-se estes aspectos, o Plantão também acaba por trabalhar junto ao tripé ensino, pesquisa e extensão de maneira transdisciplinar, observando estes vários aspectos da atuação universitária a partir de uma mesma prática.

O trabalho de Atenção Psicológica em Unidades de Internação da FEBEM iniciou-se a partir de uma demanda apresentada por mudanças internas nesta instituição. MORATO, AUN \& cols. (2002a, 2002b) relatam que, a partir do trabalho cartográfico, o plantão instaurou-se a princípio no pátio, depois em outros locais, conforme as condições institucionais. O fato de este ser realizado com esta possibilidade de transição já aponta para o redimensionamento da compreensão de enquadre terapêutico, estabelecido pelo vínculo, e não por uma padronização do atendimento. Esta abertura para o reconhecimento do que era encontrado na instituição e do que era vivido na prática clínica possibilitou a articulação teórico prática a partir da experiência, como relatam as autoras

"A partir de uma reflexão que envolveu adolescentes e plantonista, o trabalho passou a ser direcionado ao resgate do sujeito, dentro de uma instituição fechada. que se perde em meio à linguagem (gírias), aos gestos, às roupas etc. (...) O espaço do Plantão psicológico 
quebra a rotina da instituição, ao oferecer a possibilidade de apropriação de um lugar favorável para o resgate do sujeito. Concebendo o Plantão como um espaço para que os participantes da FEBEM, tanto adolescentes como funcionários podem falar de si, constituímos também um espaço onde possam ouvir a si mesmos. Dessa forma, poderíamos considerar que o plantão faz com que o participante institucional se aproprie de suas idéias $e$ concepções e, a partir disso, passe a questioná-las ou não. É a história de cada um que dá sentido à vida e é voltando a ela que pode-se pensar e refletir sobre as escolhas que se fazem no dia-a-dia.” (p. 24,25)

A própria vinculação do trabalho à experiência por ele proporcionada, a partir de uma perspectiva que mantém a abertura para a multiplicidade do real, redimensiona o cuidado com a apropriação e elaboração de sentido na formação

$$
\begin{aligned}
& \text { “Em relação aos psicólogos plantonistas e } \\
& \text { supervisores, as reflexões a respeito do sentido do } \\
& \text { trabalho aparecem de maneira constante (...) Dada } \\
& \text { a intensa absorção de um trabalho como este } \\
& \text { projeto, (...) um cuidado atento deve ser } \\
& \text { dispensado às supervisões dos estagiários” (p.30). }
\end{aligned}
$$

Na Polícia Militar do Estado de São Paulo, a partir da cartografia junto aos policiais da instituição pode-se perceber os encontros e desencontros das demandas do comando policial e dos próprios policiais (BRAGA, NUNES MORATO \& cols., 2002). Observou-se a demanda 
por outras questões tanto relacionadas à instituição militar - como a falta de reconhecimento profissional e as dificuldades de relacionamento no âmbito da instituição, entre outras - como relacionadas ao trabalho na segurança pública - como necessidade de dar conta de todas as possibilidades de uma ocorrência e o contato constante com a possibilidade da morte. Desse quadro geral e político percebemos a necessidade de

“atenção psicológica, como intervenção para acolhimento do sofrimento humano em situações de crise, a fim de compreender sua eficácia terapêutica ao desamparo e estabelecer as bases conceituais para uma intervenção clínica socialmente contextualizada e engendrada a partir do encontro intersubjetivo criado pelas práticas psicológicas em instituição, Plantão e Supervisão de Apoio”(MORATO, 2002).

Essa perspectiva possibilitou, inclusive, ressignificações teóricas, concebendo o enquadre terapêutico como se dando na relação dos plantonistas com cada pessoa que solicita o serviço, constituindo-se assim a relação terapêutica através das formas de busca e de interrelação dos policiais com o Plantão, que exigiu a ampliação da concepção de enquadre para todas as formas dos atores institucionais lidarem com o Plantão, ainda que não através de um pedido de ajuda direta, na medida em que a concepção de Plantão que se passou a utilizar foi a de um espaço para tratar da subjetividade em uma instituição que procura muitas vezes negála, havendo uma ressignificação teórica de “setting ampliado” (BRAGA, NUNES, MORATO \& cols., 2001, 2002).Observa-se também neste projeto um cuidado com a supervisão de estagiários plantonistas. 
Na supervisão é possível descolar-se da trama institucional, uma vez que o foco passa a ser os estagiários e seus relatos. Obviamente que na prática clínica proposta, leva-se em consideração diversas sensações, não somente o discurso verbal racionalizado, como tentativa de apreender a comunicação que é feita com a instituição de maneira mais global. Embora no plantão se leve em conta esses diversos canais de comunicação possíveis, o foco nesse período é o cliente.(p.28)

No Departamento Jurídico XV de Agosto, a partir da cartografia, já de início houve uma configuração inicial da forma de atendimento, que se perpetuou como a base de todo o trabalho em Psicologia no DJ, que foi o atender junto, que se iniciou começamos acompanhando os atendimentos dos estagiários em Direito que os plantonistas pudessem se aproximar do funcionamento do trabalho da instituição.

A partir da sensibilidade ao cotidiano institucional, questionou-se a proposição inicial da coordenação da instituição de os atendimentos serem realizados em uma sala isolada. Se desvelava a efetividade do atendimento conjunto. A começar pelo benefício aos clientes, que não seriam encaminhados e re-encaminhados; evitando deste modo ter de retomar junto ao estagiário em Psicologia toda a demanda emocional que já tivesse sido descarregada junto ao estagiário em Direito e também ter de voltar ao estagiário em direito caso se configurasse alguma possibilidade processual na entrevista com o estagiário em Psicologia.

O atendimento em conjunto favoreceu a disponibilização dos plantonistas no momento da emergência da questão-foco da angústia, aproveitando este momento de atendimento duplo 
Direito-Psicologia como oportunidade para o acolhimento das queixas e da expressão do sofrimento do cliente, fossem estas queixas jurídicas ou não.

Já para o estagiário em Direito mostrou-se, num primeiro momento, que é possível a aproximação com as questões humanas. Diante de uma situação crítica que escapa ao controle do estagiário em seu saber, lhe exigindo criatividade de ação e questionamento dos pilares que o sustenta em sua prática, o estagiário, às vezes, acaba por encontra-se perdido, em claro sofrimento psíquico. A partir de uma reflexão conjunta e transdisciplinar, as possibilidades de soluções inventivas eram favorecidas, possibilitando uma in(ter)venção.

\section{Meio de transporte: relatos de experiência sentindo sentidos e significando o sentido da viagem}

Entre as possibilidades de novos olhares para a realidade, diferentes da tradição metafísica, a fenomenologia coloca em cena "um ponto de tensão para o discurso tradicional metafísico relativo ao conhecimentos: o problema da perspectiva"(CRITELLI, 1996, grifos da autora), já que invoca o caráter de provisoriedade e relatividade da verdade. Assim, o conhecimento é permitido exatamente na aceitação da insegurança do existir, do desalojamento humano, no e pelo contato entre o homem e o mundo, isto é, entre o homem e a experiência que têm de seu mundo. Assim, o olhar fenomenológico possibilita o talhamento de um olhar (CRITELLI, 1996), moldando-o e despindo-o, possibilitando uma aproximação entre o sujeito moderno e sua experiência.

Para BENJAMIN, a pesquisa se mantém e se detém no estudo do fenômeno, não para dele dar uma descrição ingenuamente positivista, mas, pelo contrário, para lhe restituir sua dimensão de objeto “bruto”, único e irredutível. (GAGNEBIN, 1989) O tema da possibilidade de conhecimento a partir da formulação de sentidos sobre a prática, se coloca de maneira 
muito clara em BENJAMIN (1933, 1936, 1985). Para este autor, é a narrativa, como forma artesanal de comunicação na qual a matéria prima trabalhada são as vivências, que é capaz de dar significado e contextualização ao vivido. A narrativa se apresenta como registro da experiência, sendo por excelência a forma de sua construção e da construção da memória.

Ela se desenvolve num tempo prolongado e é objeto de um duplo processo continuado de sedimentação e reconstrução. Neste contexto, vários autores fazem a crítica ao modelo teórico-técnico, apresentando a narrativa ou o relato de experiência como possibilidade de aprendizagem significativa. A narrativa desvenda a memória, possibilitando a constituição da experiência. Assim, a narrativa se apresenta como método de compreensão da realidade, já que "Somente de posse da própria experiência é que o indivíduo adquiriria uma imagem de si mesmo, ao mesmo tempo que de sua época." (BRANCO, 1997).

Assim, objetivando clarificar as experiências que possibilitaram uma aprendizagem que é compreendida pelo sujeito através da prática e da reflexão sobre ela, própria do relatar, esta pesquisa é baseada na concepção de Benjamim acerca da narrativa, através da tomada de depoimentos, que possibilitou, através da narrativa dos participantes, o resgate do sentido da prática para aquele que narra. Considerando que " $a$ palavra experiente pode surgir no depoimento como momento de elaboração e transmissão da experiência” (SCHIMIDT,1990), a revisitação da experiência através da narrativa relatada via depoimentos mostrou-se como metodologia adequada para estudar como se mostra a apreensão e a compreensão, pelos alunos estagiantes, de modos de ação e reflexão clínica, e a possibilitação de suas reconfigurações, dependendo da solicitação dada pelo contexto, nas práticas psicológicas em instituições.

\section{1 O espaço no qual se dá a viagem: instrumentos para compreender - abarcar e entender - dando luz e sombra}




\section{Depoentes:}

Os depoentes da pesquisa foram os estagiários e psicólogos que ingressaram nos projetos de extensão universitária de práticas cínicas em instituições, desenvolvidos no Laboratório de Estudos e Prática em Psicologia Fenomenológica e Existencial (LEFE), e que participaram de pelo menos dois projetos em diferentes instituições, do referido laboratório.

Este critério foi utilizado para abarcar sujeitos que tiveram a possibilidade de ressignificar suas experiências em diferentes contextos, mas que ainda estão em fase de aprendizagem na área de práticas clínicas em instituições, possibilitando a tomada de narrativas quando estão compreendendo o sentido de sua prática, e portanto o relato de uma experiência que os sujeitos estão vivenciando, atualizando “a experiência do passado, ao mesmo tempo em que se enriquecem com aquela do presente” (SCHIMIDT, 1990) .

Estes participantes também foram estagiários participantes de uma mesma modalidade de práticas clínicas em instituições, o Plantão Psicológico, e alunos da mesma instituição universitária, a Universidade de São Paulo. Esta delimitação ocorreu com o objetivo de constituir um retrato de vivências em torno de uma mesma prática que se coloca a históricos de formação em psicologia semelhantes, possibilitando resgatar experiências em torno de um mesmo contexto.

\section{Colhendo experiências:}

A pesquisa adotou como instrumentos depoimentos dos alunos a partir de uma pergunta disparadora: "Que caminho você fez para ir compreendendo a Atenção Psicológica a partir do Plantão?". A escolha desta pergunta disparadora remonta à possibilitação, pelos sujeitos, da

elaboração de uma experiência, articulando-a através das possibilidade de uma compreensão de sua origem. A origem, para BENJAMIN, é uma noção histórico-estrutural, na qual o tempo 
histórico se constitui em termos de intensidade, não de cronologia; a origem seria, assim, os saltos e recortes inovadores que estilhaçam a cronologia tranqüila da história oficial, interrupções que querem parar o tempo para permitir ao passado esquecido ou recalcado surgir de novo, e ser assim retomado e resgatado no atual (GAGNEBIN, op. cit.) Assim, procurar-seá circunscrever a narrativa no âmbito do tema estudado, porém possibilitando a livre expressão dos sujeitos, de forma a constituir uma imagem fidedigna da vivência e da elaboração de suas experiências no âmbito destas práticas e ilustrar os sentidos encontrados para a experiência de uma aprendizagem ocorrida através de estágio em uma prática universitária de ensinopesquisa-extensão que visa construir possibilidades de uma atuação clínica mais contextualizada. . Outras perguntas foram realizadas apenas para estimular os sujeitos a prosseguir a narrativa, tais como "Explique melhor", "fale mais sobre esse aspecto”, etc.

\section{Caminhos trilhados:}

Primeiramente foram tomados dois depoimentos, colhidos individualmente. Foi solicitada aos sujeitos autorização por escrito para participar da pesquisa e para registrar os depoimentos por meio de gravador. Em seguida estes foram transcritos e foram verificados os aspectos do depoimento que ainda necessitavam de esclarecimentos para uma melhor compreensão. A partir desta verificação, foi realizada uma segunda entrevista, com o objetivo de clarear tais aspectos. Os depoimentos foram então devolvidos aos depoentes para discussão e seleção do material que poderia ser utilizado na pesquisa. Essa discussão da análise feita dos depoimentos foi também registrada. Para a análise do material, foi escolhido um dos depoimentos, que ilustrava com maior aprofundamento e pertinência a questão da aprendizagem aqui investigada, sendo que o outro foi utilizado para ilustrar os temas abordados. Além disso, a ordem de apresentação da fala foi, na medida do possível, obedecida, buscando acompanhar o 
percurso de construção de sentido pelos trilhado pelos depoentes, na realização de um diálogo com os relatos (CRITELLI, 1996).

\section{Diário de bordo: Relato de experiência construindo questões e significando o sentido}

\section{da mudança}

Antes de começar o plantão, eu estava no terceiro ano... No final do terceiro ano eu fiz "Escolar 2" com a Márcia... A gente era uma boa dupla... Então, no comecinho do quarto ano, a gente já tinha acabado o estágio de Escolar e tal... E ela ia começar a dar plantão ela fez parte da cartografia da Raposo ${ }^{4}$... Com o Maurício e com a Iara e com o Francisco... Ela precisava de uma dupla para o plantão...Porque a Iara era a supervisora de campo, o Maurício e o Francisco iam como duplas... E ela ia avulsa e precisava de uma dupla... Nós éramos uma dupla legal, ela me convidou e formamos uma dupla para o plantão... E aí a gente começou o plantão na Raposo... Junto com a FEBEM eu fazia Lugar de Vida ${ }^{5}$, fazia Iniciação Científica, fazia Métodos ${ }^{6}$, tudo no quarto ano... Atendia no LAP, que é o Laboratório de Psicopedagogia... Com jovens...e com crianças com dificuldade de aprendizagem... Fazia Métodos e, nessa disciplina, eu atendia a mãe de um menino, e depois comecei a atender o menino... Fazia iniciação com o Renato... Sobre generosidade... E aí começou o plantão no LEFE. ... no segundo semestre do quarto ano. Começou o plantão na

\footnotetext{
${ }^{3}$ Psicologia Escolar e Problemas de Aprendizagem II, disciplina do sexto semestre oferecida aos alunos de graduação, com estágio realizado em dupla, para atendimento de grupos de alunos em escolas públicas.

${ }^{4}$ Cartografia realizada no Complexo Raposo Tavares da FEBEM/SP, como est[ágio inicial do Projeto de Ateção Psicológica nesta instituição. A cartografia consistiu em um método clinico de conhecimento instituicional, com base no qual foram, posteriormente, implantadas as seguintes modalidades de Prática: Plantão Psicológico em Unidades de Internação, Supervisão de Apoio Psicológico à Equipe Técnica e Atendimento Individual, aém de uma vinculação com o Projeto de Rede de Apoio em Saúde.

${ }^{5}$ Estágio na Pré-Escola Terapêutica Lugar de Vida, vinculada ao Instituto de Psicologia da USP, que oferece estágio aos alunos da Graduação no atendimento a crianças com distúrbios globais no desenvolvimento.
} 
USP também, de Aconselhamento Psicológico ${ }^{7}$... Continuei fazendo essas coisas todas no quinto ano. No quinto ano, como eu ia fazer Mestrado, eu deixei de fazer Lugar de Vida, saí do LAP... Aí tinha acabado minha iniciação com o Renato, eu comecei a fazer iniciação com diabetes, gestantes diabéticas e gravidez de risco e continuei fazendo a FEBEM, continuei atendendo uma criança no Individual ${ }^{8}$, continuei fazendo plantão... e as matérias normais... Formei-me e prestei mestrado, aí no começo desse ano eu estava... com o atendimento da criança ainda no Individual, aí continuei na FEBEM, comecei o Tatuapé ${ }^{9}$, comecei a Rede ${ }^{10} \ldots$ E... Ah!! E eu já tinha começado em Pirituba ${ }^{11}$ no semestre anterior... E fazia "milhões” de matérias... E... Acho que foi isso que eu... que eu mantive. Eu mantive um monte de FEBEM, na verdade. E acho que não foi à toa... Eu ia fazendo as coisas e ia vendo diferenças, dessas outras coisas que eu fiz para o estágio nas FEBEMs, no LEFE... Os estágios no LEFE acabaram me direcionando... Por que eu ia sentindo, no começo... Quando a gente começa o estágio de plantão no LEFE, tentamos colocá-lo nas coisas que já conhecemos... e vai dando encrenca. Não dá certo com uma série de outras coisas. E então você vai vendo que é preciso ter uma postura diferente, que o que importa é a sua postura, e aí precisa estudar muito, eu tive que ler muito, tive que discutir muito... E acho que o que mais me faz entender... São as conversas, tanto com a Helena, ou com o Luciano, que são meus supervisores, quanto com meus colegas... Em conversas na supervisão... da aula... Tem umas discussões que a gente tem, ou tem um trabalho que a gente faz... Com a Helena... são as supervisões. ... discussões...

\footnotetext{
${ }^{6}$ Métodos de Exploração em Psicodiagnóstico, disciplina oferecida no sétimo semestre e que constitui o primeiro estágio obrigatório de atendimento clínico a alunos de graduação.

${ }^{7}$ Disciplina do sétimo semestre (Aconselhamento Psicológico I) e oitavo semestre (Aconselhamento Psicológico II)

${ }^{8}$ Atendimento Individual, modalidade de Prática Clínica do Projeto de Atençãoo Psicológica à FEBEM/SP.

${ }^{9}$ Plantão Psicológico no Complexo Tatuapé da FEBEM/SP.

${ }^{10}$ Rede de Apoio em Saúde, projeto de integração clínica entre instituições de saúde visando uma rede de encaminhamentos entre instituições.

${ }^{11}$ Atendimento Individual no Complexo Pirituba da FEBEM/SP.
} 
de qualquer tipo... Com meus amigos... conversas, no geral... Conversa sobre o trabalho.... Conversa quando sai do plantão, começa o plantão... Ou quando... se encontra e encontra um texto...

Eu lembro de uma supervisão... de uma supervisão que eu assisti do Tiago, que na verdade não foi uma conversa, foi uma coisa que ele me deu... Assisti do Tiago... e depois eu vi ele dando supervisão para outras pessoas e aí, a partir do jeito como ele trabalhava, eu percebi que eu trabalhava daquele jeito também e aí... comecei a me identificar. Com o Tiago... Os efeitos que me vieram com ele ... Eu ficava pensando no meu atendimento e ... em todos outros, assim, de perceber o sentido que a pessoa falava, e não se prender tanto ao conteúdo, e mais ao sentido... no jeito de... como fazer... É... perceber, através do que ele dizia, a forma, o movimento da pessoa... Que significado uma pessoa faz, que sentido tem o que ela está falando, e não... Não se prender ao que ela está falando, tanto, mas... ao caminho que ela fez, assim... E fora isso, nós, juntos, acabamos esclarecendo essa história de voltar para o plantão e... marcar retorno... e de fazer encaminhamento. Que horas que o outro faz o encaminhamento... Se ele está entendendo o que era o encaminhamento... Mesma coisa com o Marcos, a gente estava conversando... com... A técnica, lá (da FEBEM) de Pirituba, e o eu ouvi explicando o que era o plantão, aí me esclareceu um monte de coisas. Porque lá em Pirituba eles fazem um negócio que chama sensibilização para atendimento, a aí eles ensinam, assim... para o... para o menino o que é um atendimento... “Ah, então atendimento, você vai lá e fala o que você quiser e... sei lá, a pessoa não vai fazer relatório e etc...” Eles informam... Daí quando ele fala “'Ó, então, e no plantão eles vão experimentar...” E aí, como que essas duas coisas tinham que trabalhar juntas... Tanto a informação quanto a experiência, assim... do adolescente, para ele vir a ser atendido. Eu fiquei pensando que precisavam existir as duas coisas mesmo. E que elas podiam existir juntas, mas que nesse 
caso elas iam existir separadas.

E que não adianta a gente ficar falando - isso é o que eu penso agora - Não adianta a gente ficar falando o que é... o plantão para um adolescente que não consegue ficar lá... Se ele experimentar, ele vai saber, aí vai ficar claro, mas se ele não experimentar, ele não vai saber, e não vai adiantar eu falar... Pode ser que ele não... Não signifique nada para ele eu falar olha, eu não faço relatório... Agora, se ele experimenta e ele vê que eu não faço, aí pronto, eu não faço e... ele pode falar sobre as coisas que ele quiser. Então são umas conversas nesse jeito! Então eu acho que o que eu mais... A hora que eu mais entendi mesmo foi no começo desse ano, depois de um tempão de discussão, quando a gente começou a ter o curso, quando a gente começou a estudar teoricamente, teve as discussões... E eu tive que ler, eu tive que me deparar com os outros projetos, que eu não conhecia, e aí eu tentava estabelecer algumas semelhanças... Porque eu só fazia o plantão na Raposo, daí comecei a fazer no Tatuapé, e comecei a atender Pirituba e comecei a fazer parte da Rede... E aí... Primeiro, por partes... Primeiro, quando eu fui para o Tatuapé, eu percebi que tinham umas coisas que a gente fazia que eram muito iguais... Você precisa de um supervisor de campo no campo, você precisa de uma figura de referência, as pessoas precisam de uma figura de referência fora desse campo também, então... Uma das coisas principais, eu acho, é essa coisa de... “cuidador”. Todo mundo... Um cuida, tem que cuidar do outro, tem que receber cuidados do outro, assim, e coitada da última pessoa, porque... Plantonista tem supervisor de campo e supervisor, o supervisor de campo tem o supervisor, isso é uma das coisas... Você só consegue... fazer as coisas porque você tem uma base de segurança. Então eu percebi, por exemplo... que com (o atendimento na FEBEM de) Pirituba, para mim, ficou hiper claro, sem dúvida, cada vez mais, assim, que... Eu tive que atender com a Magali... no plantão, porque ela estava comigo ... E eu só atendi com a Magali porque eu sei quem está atrás de mim, que é 
o Marcos e que é a Sabrina, que eu posso confiar tanto, tanto, tanto... E que dão, me... Me suprem de cuidados, e eles só conseguem fazer isso porque a gente é uma equipe, e que vai suprir um ao outro de cuidados e assim por diante... Mas isso é uma das coisas mais importantes. E na Rede também... E fora as pessoas terem a necessidade de terem espaços para falar, que... Toda hora me grita isso. ...Que só precisam de cuidado e precisam de espaço para falar e serem ouvidas. E é o que eu mais percebi de comum...

Tem também diferenças... Que são os espaços diferentes para diferentes conteúdos. Então... Por exemplo, na Rede... A gente fala do trabalho e... É diferente o jeito que você chega para pessoa e alguns dos pressupostos do trabalho, então... Um pressuposto é o sigilo... Na FEBEM... Eu explicito esse sigilo assim: “eu não faço relatório, não tenho contato com a FEBEM”. Na Rede, eu vou ter uma espécie de outro jeito: "Olha... nada do que você disser vai ser levado para o seu chefe...” Mas de muito diferente são os conteúdos...Então, na nossa prática também, não é tanto o conteúdo, mas a forma, o movimento... O sentido, a direção que se vai... É... Você vê uma direção semelhante, com conteúdos diferentes... Mas é confuso para mim também... Esse “diferentes”... Até porque na Rede a gente não fez nenhuma entrevista... Eu participei de entrevista, mas não fiz nenhuma... Então... Meus conteúdos são quase os mesmos porque... Eu só trabalho com adolescentes. Eu só trabalho com FEBEM, e todo dia é a FEBEM... Assim... Apesar de ter suas peculiaridades, cada menino, cada vez que atende... Muitas vezes acaba... Acaba que cai na mesma conversa, aí você puxa para o que tem de diferente em cada um deles, mas... Muitas vezes acaba caindo na mesma coisa, assim... E aí tem um jeito... de pensar...o atendimento. Eu não sei se vou... saber falar... Mas eu tava conversando com o Marcos, a gente tem “a prioris”, eu acho. Ou “eu” tenho, não sei se é “a gente”... Nunca compartilhei... Primeira coisa - eu vou falar de FEBEM porque adoro FEBEM... Não tem jeito. Primeira coisa: eu não faço relatório, então, eu garanto sigilo 
absoluto e isso faz parte do meu... dos meus "a prioris" e eu vou... Carregada disso. Eu não faço relatório, então, meu sigilo está garantido. A outra questão é: eu me respeito, então... Eu não vou passar do meu limite. E eu vou respeitar o outro. Nesse caso, o adolescente que vier até a mim. E aí, eu espero que ... O vice-versa aí aconteça, e então ele se respeite, ele não vá passar dos limites que ele não quiser, e também não vá me cobrar que eu passe dos meus, e aí se cria um respeito mútuo. E a outra coisa que eu acredito é que "a priori" a gente confia muito. Então... Eu tento... Não generalizar nada...

Então, por exemplo, um menino foge, como que aconteceu... Um menino foge daqui (do prédio de atendimento clínico da USP) e aí eu vou tentar ao máximo não generalizar, não é porque um fugiu que outro tem que ser castigado. Então, "a priori”, eu vou confiar e... Eu confio em nossa relação, em nosso vínculo que vai se estabelecer... E no começo isso é uma crença, porque... Como é que eu vou saber se isso vai acontecer mesmo? Mas é um "a priori”... Uma coisa meio assim, de “mergulhar"... Eu, eu vou, eu me entrego... E me entrego inteira...Me abro... E falo "Olha... Vem aqui, e vamos conversar...” E aí eu sei que eu espero... Que essa relação se estabeleça, que esse vínculo se estabeleça, e que por respeito a isso... Nada aconteça. Então... É ilusório achar que eu nunca vou ser pega numa rebelião, mas eu "a priori" eu vou ter que acreditar nisso, porque senão eu não vou conseguir... Ir para o pátio. Ou então... Eu juro que eu acredito que o menino não vai fugir da clínica, porque senão não há como eu mandar tirar a algema para ele... Entrar comigo na sala. E aí a partir disso eu acredito mesmo que uma relação se estabeleça, um vínculo se estabeleça de confiança... Igual ao de respeito.

O que eu mais... discuti com o Marcos, faz umas duas semanas que eu estou pensando nisso, assim... É que não existe causa-efeito... não existe... "Se eu fizer isso vai acontecer isso com certeza”. E é isso o que mais me incomoda nas teorias em geral, assim... Quer dizer... 
Você não tem um... um fim específico. Você pode até esperar que algumas coisas aconteçam, que nem eu falei "Olha, então eu confio no menino e acredito que possa acontecer de ele nunca entrar para a rebelião”... Só que... Se me pegam... de repente... o que eu posso fazer? Por que... o "sim", então...não existe. Quase nunca... É muito difícil fazer alguma coisa e prever um resultado... com gente... não dá... É... num humano, é muito difícil... Não dá para você generalizar e dizer que está tudo muito claro... Mas... em outras... experiências minhas eu conseguia fazer isso... O que mudou? Eu acho que uma das coisas que mudou foi o meu jeito de olhar a situação... Por que... Por exemplo, mesmo no LAP, quando eu fazia estágio com as crianças, que eu achava que a teoria ia direitinho...

Hoje, quando eu tenho a mesma teoria... e as mesmas crianças... São as mesmas crianças e a mesma teoria e o mesmo professor. E eu olho e falo "Puxa vida, ele nunca me prometeu nada mesmo!" Sabe? Ele nunca falou assim "Vai na fé com isso!" Tanto que agora, que eu vi numa matéria, ele fala "Olha, tem tantas, são tantas as condições, que você pode oferecer as condições, mas todas as condições são necessárias, mas elas não são suficientes. Então, você não pode prometer nada mesmo, nunca! Entendeu?”Então talvez seja isso, talvez eu seja ingênua a tal ponto de acreditar que - sei lá - se eu fizesse uma coisa, eu teria um resultado certo... E não é... Como foi ter quebrado a cara? Ruim demais! É muito ruim... Porque, por mais que a gente, por mais que eu fale "Olha, eu não acredito mais... que isso leve a um resultado determinado...”, a gente sempre espera que esse resultado aconteça. Então... se eu vou para a FEBEM e eu converso com o menino, eu falo: “Não, eu não quero tirá-lo do crime”, mas se ele sai, eu fico feliz. Então, lá no fundo, lá atrás, eu acredito mesmo que um dia ele vá desistir. E não que isso vá acontecer toda vez que ele quebrar a cara e toda vez eu ficar triste quando o menino voltar ou para a FEBEM ou for morto à toa... porque não adianta, ou a gente se sustenta desse jeito, de todas as vezes acreditar, e esperar, e enfim, 
quebrar a cara, ou então... Eu continuo esperando, mas agora espero sabendo que não vai ser possível... Quando a gente viu a aula do Arthur, ficou mais, mais claro para mim... Você não pode deixar de acreditar na potencialidade da pessoa que está falando com você. Então eu não posso deixar de acreditar que um menino possa sair do crime, ou que ele possa continuar no crime e morrer, ou sofrer, enfim... E eu vou quebrar a cara junto com ele, porque eu entrei nessa dança com ele, eu comprei o sonho dele e a gente vai sonhar junto e vai quebrar a cara junto. O Maurício sempre fala: "Olha, não eu não acredito, mas na verdade lá atrás, lá atrás eu acredito e é isso que faz o meu trabalho dar certo.” ...Toda vez eu vou acreditar e quebrar a cara junto com o cara porque toda vez vai ser uma pessoa diferente. E aí eu vou ter que comparar esse esquema com ele... (risos) Difícil...Por exemplo: a gente na FEBEM... - só sei falar disso, mas... - A gente na FEBEM tem que saber... que os meninos podem ser violentos, podem ser agressivos... mas que isso não seja muito taxativo... “Olha, eles são agressivos e ai, meu Deus! Já era! Esqueça-os! Deixa eles lá!”.

E... uma das coisas mais gritantes em supervisão, também, de diferente... É que todas as supervisões que a gente tem aqui, tanto na Helena, como na do Luís, como a Vanessa... como as que assisti... Elas perguntam, todo mundo pergunta... "O que é que você sentiu na hora em que estava atendendo?” Ou... "Como é que você se sentiu quando a pessoa respondeu isso ou aquilo?..." E você se ter como referência na hora do atendimento é uma coisa que ninguém ensina... Então... O que eu senti só é importante aqui. Em outras supervisões nunca foi. E é o que mais me instrumentaliza... Porque a partir do que eu senti e percebi que eu vou poder intervir... Então fica fora do racional... Porque nas outras sempre teve isso de... “Ah! Então ele diz tal coisa, então é isso...” Então... É muito difícil ter essa preocupação... É... Uma diferença entre discutir o caso e discutir "eu atendendo"? Acho que tem essa diferença... Uma diferença do jeito como eu estou lá, na situação... Aí, por mais 
que... Eu estava lembrando: a minha supervisora também tinha isso de perguntar como é que eu estava no atendimento... Mas era diferente, mesmo assim! Era como eu estava para saber como agir com ele. E aqui não, é como eu estava e que cuidados. É preciso ir comigo para... Para daí intervir nele, e tem esse aspecto de "Ah! Deixa-me respirar e separa 'meu - seu' e... e devolver o que é dele para ele, mas essa preocupação é só quando eu estou aqui. Por que aqui eu não consegui encaixar meus guias no estágio? Acho que, primeiro de tudo... A gente começa com o estágio. A gente não aprende nenhuma teoria antes de ir para o Plantão. Pelo menos eu não aprendi... A gente começou a dar plantão seis meses antes de ter a teoria... E... aí tem muito a ver... com o que eu faço... que é atender na FEBEM... Que é outra realidade, os meninos pensam... Eles passam coisas que eu não passo e pensam coisas que eu não penso e... Eu não sei explicar muito, mas... Não existiu nenhuma teoria que eu falasse: "Nossa! Olha só! É assim que as coisas se dão e é assim que eu vou fazer para melhorar... O jeito como as coisas se dão, assim..." Não consigo ver teorias que dêem certeza de um resultado... E essa atitude... Eu acho que nos projetos que eu participo, e eu acredito que nos outros também, não sei se é tanto a linha teórica que cada um segue ou a abordagem que cada um gosta mais... É mais uma disponibilidade, um jeito de pensar, uma atitude, um jeito de se colocar frente à outra pessoa. Eu não sei como eu fui compreendendo esse jeito... Eu acho que tem um monte de coisas: meu jeito de atender frente aos meus outros colegas de graduação - então em outras supervisões eu ia percebendo que eu tinha um jeito de estar que era diferente... Por exemplo: esse lance de a gente atender fora de um setting tradicional. Tem um monte de gente que é contra... Eu sou muito mais a favor que tudo comece fora de um setting tradicional $e$ que depois se configure uma demanda e que aí se configure uma psicoterapia do que jogar direto a pessoa na sala e aí tentar fazer com que ela descubra a demanda dela... Então tem essa diferença de...de setting, tem a diferença de postura, então a gente não fica quieto, a 
gente intervém... Eu acho que determinadas coisas, que são fundamentadas em outras teorias, para a gente não fazem tanto sentido... Então, a gente não pode ter uma postura muito imparcial... Não sei explicar. Mas, por exemplo, você não pode só escutar ou não pode deixar de falar da sua vida. Você está lá na FEBEM, o menino pergunta onde você mora e você tem que responder por que... isso vai garantir a sua confiança, a manutenção do seu vínculo... Não tem como você falar “-Ai, não, não posso” ou então devolver “- Mas por que você quer saber onde eu moro?” Não. Responde, daí você mantém o vínculo com ele... e daí pode começar a sair um atendimento e então ele começa a falar dele... Então tudo começa a se configurar. Eu acho que é muito isso. Essa disponibilidade que se tem O menino está lá, fazendo dobradura: você tem que sentar do lado dele e fazer com ele um tempão, para adquirir confiança com ele, e aí ele começar a se abrir... Então é muito diferente de atendimentos tradicionais. Isso, vamos dizer assim: explica a atitude que você tem que ter. Mas eu fui percebendo que precisava ter essa postura ... Acho que pela prática. Desde o começo quando a gente chegou lá... no meu primeiro dia. Eu vou começar a fazer um estágio e aí chego lá e... é um bombardeio de perguntas que você vai ter que responder. Então, para descobrir qual a minha postura, eu fui fazendo, fazendo, fazendo... e foi aí que eu fui construindo a minha postura. Não dá para não responder, não dá para ficar quieta no meu canto, não dá para não intervir, não dá para fazer um monte de outras coisas que se faz normalmente, que não cabe... não tem sentido. É como se as coisas que você aprendeu não fizessem sentido, então eu tive que construir um outro jeito. E agora não existe mais o jeito de antes, assim. Não consigo fazer de outro jeito. Mas é, eu acho que um monte de a prioris que a gente tem quando a gente... Quando você começa a estudar como é que se atende, você estuda conceitos como transferência contra-transferência, a entrada da pessoa na sala, tal e você começa a ter um monte de a prioris, e esses a prioris na maioria das vezes são 
derrubados nos estágios que a gente faz. No Plantão, na instituição, não tem como você ficar... não tem como você garantir uma posição de hierarquia com a pessoa, enfim. Um monte de coisa derrubada. Não sei explicar. Aí você chega lá com os seus a prioris e você vai percebendo que isso começou a ser derrubado... E aí tem que explicar, depois... E aí você vai ter que tentar explicar tudo aquilo que você faz a partir de alguma teoria, ou a partir de um... Sei lá, você vai tentar... eu ficava tentando encaixar. Então, sei lá, eu pensava: "Ah, então eu tenho que responder às perguntas deles. Então eu não posso ter uma postura imparcial frente a... frente a eles. Então eu não gosto de teorias que me mandem ter posturas imparciais." Então, é... tem determinadas teorias que me dizem: “Ó, então você tem que atender numa salinha de tal e tal jeito." Não dá. Não consigo, não gosto... Então tal teoria eu jogava fora. E aí foi meio assim, sabe, foi meio fuçando teorias, e ainda não consegui achar... Acho que é como - eu estudo bastante Piaget - como esses processos de acomodação: você tenta assimilar de qualquer jeito, a qualquer custo aquilo que você está vendo com aquilo que já tem. Só que você vai vendo que não vai dar, então você vai tendo que adaptar aí as coisas... Uma hora, outra hora, assim, e aí você vai tentando uns acordos, você com você mesmo... uns acordos com as coisas que você acreditava, então... Sei lá, eu curto bastante psicanálise. Curto bastante, assim. Só que tem algumas coisas de psicanálise que não dá. Não cabe, assim, que fica insuficiente então... Eu ler tudo via complexo de Édipo, eu sei que tem determinados contextos que isso cabe. Lá, precisa de alguma coisa além disso, eu acho. Ou então... Sei lá. Eu penso muito nessa coisa de setting... Não adianta eu pensar que eu vou para lá e vou... o menino vai ser encaminhado para mim, eu vou conseguir atendê-lo numa salinha... e que... qualquer pergunta que ele me fizer eu vou devolver ou querer saber por quê ele faz essa pergunta... Não. Eu vou responder. E vai ser no pátio, então... a gente tem um outro tipo de atenção, eu acho. Que não tem outro nome a não ser atenção por que... a palavra 
atendimento vai bater com um monte de outras coisas, com um monte de a prioris, com um monte de pressupostos de outras pessoas e não vai combinar. Então atenção é uma palavra nova, eu acho, que combina mais. Que nem plantão, eu acho. Plantão é uma palavra que combina por que está ali, não é? O negócio está ali fervendo, você vai lá e... e olha. Você cuida ali, na hora. Mas tem um monte de gente que... usa esse nome plantão e que não é o que a gente faz, também... Então, a gente tem um fazer que é completamente diferente de um monte de coisas que acontecem... e que a gente não consegue dar nome e que não adianta ficar tentando encaixar por que a gente não vai conseguir. Mas para ir compreendendo isso... ir construindo isso... Na hora que destruiu fui buscando... a primeira coisa que você fiz foi ir buscar a teoria... a primeira coisa foi o que é que explica aquilo que eu faço. E aí nenhuma explicação era suficiente, então... Não sei ainda, direito... Não dá para saber como eu fiz por que eu acho que a gente não fez, eu ainda... espero respostas... ainda... sou um bando de perguntas... Até agora eu estudei bastante. Então, eu fui procurar explicações em Institucional, que eu faço... Em parte elas são suficientes, mas chega uma hora que ela pára... E aí agora a gente está aí... Fazendo o curso... fazendo grupos, e... bom, eu vou escrever o mestrado... Todas as perguntas eu acho que me... me fazem ter vontade de estudar mais, assim. Para tentar entender o que é que a gente faz. Não que eu ache que eu não compreendo, eu acho que não sei explicar. Para explicar precisa de palavras. Eu sei o que eu faço por que eu faço. Então sei que eu chego lá, eu sei que eu ando, eu sei que eu cumprimento, eu sei que eu converso, eu sei que eu respondo... Eu sei a prática. Mas eu não sei... Se tivesse que ensinar para uma pessoa: "Ah, e aí, que mais é que você faz?" Eu ensinaria... que nem quando a gente dá plantão. Você ensina, você fala: “Ó, então você entra na sala explica para pessoa o esquema, e aí... escuta o que ela tem para falar.” O que vem depois do que... dessa hora, "escuta o que ela tem para falar", cada um vai ter que aprender. Você vai ter que 
aprender sozinho, você vai ter que ver... Aprendi isso fazendo. Fui lá, fiz, voltei, fiz supervisão, fui lá, fiz de novo, voltei, fiz supervisão... E o que aconteceu... o que acontece... No meu primeiro plantão, deixa eu pensar... Então... Fui lá... A primeira coisa: você não pode ter medo de...de ser você, isso eu aprendi. Então...Sei lá, você tem que ser hiper sincera você tem que estar hiper aberta, ser hiper sincera, não pode se mostrar dona de saber nem dona de poder. Então beleza - você chega lá e fala: “Ó pessoa, vou te ajudar aí no que você precisar, no que eu puder” ... Por que eu estou disponível, eu estou entregue... Oferecendo um tipo de relação de compartilhar com ele do sofrimento dele...Então eu digo: “Eu vou tentar estar com você... Olha, me dá a sua mão e vamos juntos!” E aí a pessoa começa a falar... E aí não sei muito como é que é. Não sei como se dá isso, assim... Vai tentando ajudar, no começo eu acho que a gente é muito... Muito uma lixeira, assim, sabe, a gente recebe muito, a gente capta muito, sente muito e se autoriza muito pouco a falar. Aí você desce para supervisão e fala: “olha, a pessoa falou isso, isso, isso...” E aí a pessoa que te dá supervisão fala: “mas aí o quê que ce pensou sobre isso?” Você fala: “Ah, pensei tal.” “- Mas você falou?” “-Não, não falei” “- Então fala da próxima vez” E aí da próxima vez você vai tentar falar... aquilo que você sentiu, aquilo que passou pela sua cabeça. E assim por diante... Cada vez mais alguém vai te autorizando a falar e como esse alguém você acredita saber mais do que você, você se autoriza também. Acho que mesmo coisas simples... Por que o outro está autorizado a te dizer o que você tem que fazer... Por que você acredita que o outro seja dono de um saber maior que o seu. Então... A pessoa tem pelo menos mais experiência. Então ela vai saber mais ou menos se você fez direito ou não. Então, se você achou que fez direito e ela também, então você se autoriza cada vez mais a fazer. Assim: a pessoa ia lá e me falava. Aquilo me batia de alguma forma... Só que eu não sabia... Se podia... Devolver isso para pessoa ou não. Aí, quando ia na supervisão, o que acontecia para eu ir compreendendo é que o supervisor 
começava a dizer... A me autorizar a devolver aquilo que eu sentia...

Eu estava pensando agora... Teve uma aula do Gilberto, eu acho, que a gente fez, que ele falou que... Ele falava assim: que a pessoa espera, a pessoa que vem te procurar, ela está sentindo tudo. Ela sente tudo, e é um bando de angústia. E que conforta você dar nome àquela angustia, então... Ele contou uma história de um menino que estava apaixonado... nunca vou esquecer, assim, o menino estava apaixonado, estava sentindo umas palpitações, não sei o quê, não sei o quê, não sabia o quê que era. Ele falava: "Ai, eu vejo a menina eu sinto palpitações e aí ela não pára, não pára, não consigo parar de olhar essa menina, não sei o quê..." E aí o terapeuta virou para ele e falou: "Ó, então você tá apaixonado?" Pronto, sabe. Aí ele viu, assim. Aí ele viu tudo... E aí eu acho que a gente talvez imagine que as nossas intervenções tenham que ser enormes, sabe, mirambólicas, assim, sabe. Você tem que fazer aquela construção enorme, não é... Você sabe que a pessoa está triste e você não sabe nem se vai falar “Puxa, como você está triste”... Que é uma coisa tão... que parece tão pequena e que para pessoa vai ser tão grande... Acho que essas intervenções pequenas a gente deixa de fazer. Que a gente desconfia que elas não vão ser legais. E aí você tá embebida dessa tristeza a hora que você vai para a supervisão. E você não sabe direito o que é que você está sentindo e alguém vira e fala para você e dá esse nome e fala: “Então a pessoa estava tão triste...” E aí você fala: “Puxa... a pessoa estava triste.” E aí você fala: “Nossa, então da próxima vez eu posso virar para ela e falar: 'como você estava triste’” E aí eu acho que vai meio nisso... Por que...Como no começo você só recebe, por que você não se autoriza a falar, você desce do jeito que... do jeito que a pessoa estava. E aí na hora que você chega lá e tem a supervisão, a pessoa vai te nomear tudo aquilo que você está sentindo... E aí, pronto: você vai ver que da próxima vez dá para você chegar lá e fazer isso com a pessoa, que vai ser suficiente. Agora eu acho que eu ando muito mais no caminho de entender aquilo que eu faço, primeiro, para 
depois buscar uma teoria. Construir a minha explicação... Por que... porque eu não sei, eu sempre tive essa coisa de: "Ah, então eu aprendi tal conceito e acho que esse conceito se encaixa com o que eu fiz ali." Só que daí você vai vendo que vai ter umas horas que não vai encaixar, não vai encaixar, não vai encaixar... Então... Puxa, então pára e pensa: “O quê eu faço ali?" O quê eu faço, ou no quê eu acredito, qual é a minha postura, como é que eu me abro, como é que eu me fecho... Enfim... Qual que é o meu movimento, primeiro, para depois eu tentar buscar em algum lugar... esse movimento que eu faço. Por que senão vai ficar uma loucura de teorias, a minha cabeça... Antes o que eu faria seria tentar pegar a teoria e colocar na prática, aí agora eu tento... quando comecei a fazer isso, tive que ir... da prática para a teoria...Teorizar aquilo que aconteceu....

É mais fácil explicar de um dos meus estágios. Eu fiz um estágio com criança na época que eu estudava Piaget. Então, você tem ali a teoria... Tá ali, a teoria é clara. E a do Piaget, por exemplo é muito clara, ela é muito bem articulada, tipo dá direitinho assim. E aí, beleza: eu ia lá para o meu estagio, lia as crianças de acordo com essa teoria. E pronto: ia embora para casa fazia o relatório do que estava acontecendo e estava satisfatório. Combina... Bate. Encaixa direitinho. Chega uma hora que começa a faltar coisa, então... Piaget estudou a inteligência, falta a afetividade. Então o quê se vai fazer com a afetividade? Então vai procurar no Freud a afetividade. E aí, puxa, o cara não é... Eles não se encaixam perfeitamente, como é que você vai fazer para encaixar os dois? Toca estudar para caramba para tentar encaixar um no outro. Nesse estágio não da para fazer isso...(risos). Não deu, pelo menos, até agora, assim. Então, a supervisão... Você vai lá pensando um monte de coisas que você não consegue dar nome... ou às vezes até sabe o nome mas não se autoriza a falar. Quando você chega na supervisão, o supervisor de certa forma faz com você o que você vai fazer com o cliente...E aí eu estava pensando aqui. Eu acho que além da supervisão... Aí vem 
a minha confusão. De não saber se é o nosso jeito de trabalhar ou se todo mundo trabalha desse jeito. Por que a gente capta muito... Eu tenho uma impressão que a gente é tipo um urso... Que vai e abraça a pessoa, capta todo sentimento dela. E depois metaboliza e devolve, assim. E aí eu fico pensando que... Não sei se é o jeito da gente trabalhar, não sei se todo mundo trabalha assim, mas é o jeito que eu entendo para mim. Precisa da supervisão, para me dizer o que é do outro, mas precisa da minha terapia, para me dizer o que é meu.

Por que... aquilo que eu senti só me pegou por que eu também senti alguma vez. Então eu lembro de uma vez que eu estava na FEBEM e alguém perguntou acho que foi para a Iara: “Ah, mas como você sabe... você não sabe o que é estar sozinho aqui. Aqui dentro da FEBEM...” E aí a Iara respondeu: ”Ah, mas... Eu não sei o que é estar sozinho aqui, por que eu nunca estive aqui, mas eu sei o que é estar sozinho.”Então, deve existir algum tipo de... Existem alguns sentimentos que devem ser meio universais, assim, eu acho. Por exemplo, solidão. Todo mundo já sentiu algum dia solidão. Como é que você vai perceber que o outro está se sentindo sozinho: por que alguma vez já... você já se sentiu daquele jeito. Na hora que a pessoa fala aquilo ecoa de um jeito em você e você consegue - não sei se consegue...no começo você não consegue - mas você aprende a falar para ela "Puxa, acho que o que você está sentindo é solidão”. Mas por que eu reconheço em mim, sei aonde me toca e aí eu vou saber, então isso aqui é da pessoa. Agora, para aprender a fazer isso... eu não sei. Precisa fazer muito, assim, eu acho. Precisa... Você não consegue aprender a atender sem atender... muito... sem ser questionado para caramba e sem sofrer muito, assim. Por que eu não encontro nenhuma outra via... Um atendimento vai mexer com coisas suas, então você vai ter que se abrir para... ser mexido. Então... isso vai doer. Por que não é... Ninguém vem feliz da vida. Procurar a gente. Todo mundo vai vir ou se sentindo triste, ou se sentindo mal, ou se sentindo sozinho, ou com saudades, ou... enfim. Com esse bando de sentimentos que a gente 
evita... de perceber... na maioria das vezes... no decorrer do nosso dia a dia. Nos nossos atendimentos, é justo aí que a pessoa vai pegar, então... Vai doer, você vai precisar de ajuda, você vai precisar de um... Estava pensando... eu sempre precisei de um grupo muito legal de supervisão, por que a supervisão vai dizer de coisas suas e vai ter que ser um grupo que...que receba bem. Vai precisar de um supervisor que te cutuque de um jeito... legal. Que tem supervisores que só vão discutir o caso e não acho que é isso que tem que ser... Por que não adianta você só saber do outro. Você vai ter que distinguir em você o que é seu e o que é do outro. Se o supervisor só vier no que é do outro, eu não sei, não fica completo, assim. Você tem que perceber em você o que é que aconteceu para você saber dizer do outro. Então... para ir compreendendo isso daí eu precisei entender o que estava se passando dentro de mim, na hora do atendimento... Para poder devolver para o outro aquilo que era dele, também... E ao mesmo tempo me autorizar a isso... Eu fico pensando: tem atendimentos que às vezes a gente não dá conta... É por que mexeu em alguma coisa que você ainda não mexeu. Então... sei lá, eu tenho um lance de querer respostas para tudo, mas tem coisas que não tem resposta. Se alguém que eu atendo me mostra isso: “Olha, então tem coisas que você não tem resposta"... Enfim, aquilo vai mexer comigo de algum jeito, vai ser um atendimento do qual eu não vou dar conta, e aí... Eu vou levar para supervisão e vai chegar nesse ponto: "Olha, tem coisas que você não dá conta. Tem coisas que você não vai ter resposta." Mas eu fico pensando... sei lá... em outros atendimentos... que antes eu não conseguia dar conta então: "Ai..." Por exemplo, eu lembro ano passado uma vez que eu procurei a Helena por que o menino só chorava no atendimento e eu não estava conseguindo, estava demais para mim. Aí ela falou para mim: "Olha sentimento demais te causa esse mal." Mas me causa, sabe, não é... "Ai, nossa o sentimento está causando um mal na outra pessoa, a outra pessoa não está se agüentando..." Não. Me causa esse mal, vai ver o que é seu aí. Por que daí você pode 
responder para o outro. Por que às vezes você acha que é insuficiente para o outro uma coisa que você fez, então: a pessoa está chorando muito. Você fica do lado dela, é suficiente. Ela precisa de companhia para chorar. Você vai chorar junto com ela e pronto. Às vezes para ela, está beleza. Mas mexeu com alguma coisa sua. É no seu que você vai ter que ver. Por que do outro você já se ocupou de dar uma resolvida, ali. Você estava ali do lado da pessoa, você acompanhou o sentimento com ela, sobrou um pouco em você, mas é seu. O que sobrou. Do outro você deu conta ali, mais ou menos. Se... se você não percebeu o quê que é seu, da próxima vez você não vai conseguir devolver. Mas é muito difícil.... Eu não sei te explicar o que é que acontece... Eu não sei.

Tem isso, tem... Acho que nessa hora eu concordo muito com a psicanálise pelo critério que ela pede. Sabe, você precisa de... você precisa de psicoterapia, não acho que você dê conta sozinho das coisas, você precisa atender e ter supervisão e você precisa estudar. Você precisa dar nomes paras coisas que você sente... Primeira coisa, aí seu terapeuta vai ajudar, enfim. Você precisa atender senão você não vai conseguir saber como você percebe o outro. E você precisa estudar por que, meu Deus, você precisa ter uma explicação minimamente científica para aquilo que você faz. Não sei se científica no sentido de sei lá, qual ciência, mas uma explicação para poder chegar até uma outra pessoa que desconhece completamente aquilo que você faz e falar para ela: "Olha o que eu faço é isso, isso e isso, e tem esse, esse e esse nomes”. E aí a partir daí dá para sentir... Essa explicação é... Primeiro para gente conseguir entender... Por que a gente também precisa de nomes para além dos nossos sentimentos. A gente precisa de nomes para aquilo que a gente faz. E depois para ter interlocução. Sem nome você não consegue ter interlocução nenhuma, fica meio... "Ah, eu acho que o que eu faço é isso, isso, isso... Ah, sei lá." Fica meio senso comum, sabe, eu tenho muito medo de senso comum, de... as coisas precisam ter muito nome, muito bem constituído, 
com uma explicação direitinha, para as pessoas não acharem que é senso comum e para eu ter possibilidade de interlocução. Por que senão...não tem como você criticar... Senão você vira e fala: "Ah, tá, você faz isso, você..." Sei lá. Sei lá, você... você aconselha, mas você dá conselho no sentido de... tipo padre, sabe: “Ah, você dá conselhos...” E pronto, e desmerece a sua atuação. Então não sei... quando eu busco a teoria, quando eu estudo para saber aí o quê que é que a gente faz... É muito por que eu acho que se a gente não tiver as coisas bem construídas teoricamente, a gente não tem possibilidade de interlocução por que as pessoas não dão crédito. Mas é muito difícil.

Mas eu fui apreendendo isso... .Eu não sei, assim, eu vejo transformações em mim. Foram acontecendo ao longo do tempo, então.... Eu não sei, assim...eu vejo por exemplo no começo da FEBEM... Que a FEBEM para mim ela é um marco, começar a FEBEM... Então, sei lá, eu tenho... Uma vida antes da FEBEM e uma vida depois, assim, por que acarretou um monte de mudanças em mim. Então... Eu não sei, eu...eu...eu fico pensando que eu...passei a questionar mais as teorias ...mas é...é fazendo, eu não sei explicar muito como é que essas transformações foram acontecendo... Não sei eu fico imaginando sei lá, quando a gente começou. Então, sei lá, eu estava o quê? No quarto ano, então... eu comecei Métodos junto com ... com a FEBEM e junto fazia grupo de Piaget e Junto fazia grupo de Freud e junto, enfim, fazia um bando de coisas... E, no começo, acho que a FEBEM causava muita angústia...por que ela não se encaixa mesmo em nenhuma dessas coisas que a gente faz. Então eu ia a campo, não ficava em uma salinha, trabalhava com adolescente, que tinha metade da cabeça de criança, metade de adulto, então o povo não se encaixa com nada do que... que ninguém diz para mim! E... Eu tinha que pensar, deixar de pensar o crime de um jeito valorativo como eu sempre aprendi. Por que daí eu não ia ter como chegar até eles Então, olha, é pancada atrás de pancada. Então, sei lá, você atende o menino e lógico que no 
começo você acredita que você vai salvar o cara, você vai tirar o cara do crime, enfim. Precisa de uns dois ou três provar para você que você não tirou... Para você começar a falar: “Puxa, então o meu objetivo não tem que ser esse”... Ou então, precisou eu atender um menino que se sentia muito sozinho para ver que a minha função era... Uma das minhas funções era agüentar aquela solidão toda junto com eles. Eu estou meio no fazer assim... Eu tive que ir muito, eu lembro que o nosso grupo no começo sonhava muito com aquilo lá... Por que é muito diferente de tudo, né, você está lidando com uma população que não é a sua... Por que foi mal, mas eu sou boy (risos). Eu sempre falei: “Foi mal, sou boy, minha vida é outra, eu tenho dinheiro, eu tive pais que me criaram, enfim”.Então, todos esses pressup... Todas essas coisas. Por que a gente vive numa caixinha de, numa redoma, muito, sabe... Toda essa redoma teve que quebrar. Então, tem gente que passa fome, mas tem gente que também não passa. Desculpe, eu não passo, mas eu venho aqui ajudar_você que... Por acaso pode ter passado fome. É... Eu tenho dinheiro e eu falo sempre assim: “Foi mal, eu tenho dinheiro, mas eu venho aqui." Foi mal nada! Eu tenho dinheiro, você não teve, eu venho aqui, a gente tenta caminhar aí para ver se a gente chega ... Por que eles colocam no começo um limite muito firme, assim, do tipo "Você é boy e eu sou do crime". E não é. Você vai acabar encontrando alguma coisa que te dê... alguma semelhança entre você e aquela pessoa. Então, eu lembro que a Helena falou que alguém tinha ido na FEBEM, sei lá, tinha falado dos cheiros: "Ah, é o mesmo cheiro de não sei o que lá que eu vi." Sabe? Então, por exemplo, é o mesmo cigarro, que eles fumam nosso é o mesmo cigarro, é verdade. Na FEBEM eles fumam o mesmo cigarro que os meus amigos. Por essas vias você vai desconstruindo uma imagem de cisão absoluta, sabe... Entre você e o seu mundo e entre eles e o mundo deles. No começo a gente sonhava, tinha muitos pesadelos com o crime. A gente teve uma coisa que tinha que mudar, o meu grupo. A gente teve que ter no decorrer do trabalho uma relação afetiva muito 
forte para dar conta... para dar conta desse estágio A gente... eu lembro que no começo eu achava que ninguém ia entender, que ninguém ia me entender mais. Por que a FEBEM me tocava de tal forma que só as pessoas que foram tocadas tanto quanto eu que iriam me entender.

Então quando eu fui assaltada, fazia três meses que eu fazia FEBEM. Eu tinha acabado de contar para os meus pais. Deu uma treta enorme... Que eu contei para os seus pais depois que eu comecei a fazer... Tinha que saber se eu ia gostar, por que eu não vou contar para os meus pais se eu não gostar, então eu vou descobrir primeiro se eu vou gostar. E gostei, deu um tempo eu contei para eles, deu duas semanas eu fui assaltada. Meu pai é japonês tem todos os valores muitos bem constituídos. Imagina, ladrão para ele tem que tudo ser bombardeado, tem que morrer todo mundo. E aí fui assaltada e aí nossa, que treta na minha cabeça, meu, por que... aí foi a hora que meu pai falou: “Tá vendo? Não quer matar esses dois?" Falei: "Quero. Esses dois eu quero matar". E... queria matar mesmo, eu não voltei na FEBEM durante um mês. Mas aí eu sabia, vinha para ter supervisão. Por que era o único espaço onde eu me sentia acolhida, à vontade e compreendida. Por que eu achava que só as pessoas que passaram pelo que eu passei, então, só quem tinha ido para FEBEM ia entender o que é que eu estava sentindo. Então tem isso. É... é doído, assim, por que você não... você vai se achar incompreendido por um monte de outras pessoas... Então: puxa, como é que você vai explicar para alguém que você atende no pátio? Se todo mundo atende na sala... Como é que você vai explicar que dá para você atender no pátio? Que você atende, beleza... mas que dá para um atendimento acontecer de um jeito superlegal! Como que você vai explicar? Não dá, tem que experimentar. A pessoa tem que ir lá e ver. Acho que isso é o mais difícil assim. Como é que você vai... como é que eu ia explicar que eu estava tão zoada na minha cabeça por causa do assalto? Se ninguém tinha ido para FEBEM comigo, só 
aquelas meninas? Então, eu vinha para a supervisão e explicava: “Ó, estou zoada... Não estou conseguindo dar conta...” E aí você vai indo, é um trabalho meio do grupo tentar... tentar se entender, tentar se dar o lugar... No começo seu lugar é só naquele grupo...

E aí depois foram acontecendo coisas do tipo: a Silvana e a Maíra foram embora e a gente teve que enfiar pessoas novas no grupo, e aí teve que explicar para eles o que é que a gente fazia... e... Mas desde antes, eu lembro quando eu fiz institucional. Foi a minha primeira leitura que eu tentei fazer do nosso trabalho. E aí me confortou absurdamente por que dá para você... encaixar algumas das coisas. Então foi algum jeito de alguém ler aquilo que eu fazia. Mas antes eu precisei descrever muito bem: “Ó, eu chego no pátio, cumprimento todo mundo, não sei quê, não sei quê..." E aí depois ler assim: "Essa parte talvez se encaixe com tal conceito, essa talvez com tal, essa com tal, essa com tal", e aí foi dando uma... todo um contorno para o nosso atendimento, para o nosso fazer, que foi superlegal, o trabalho ficou legal, enfim. Mas precisa de umas construções e umas desconstruções... a todo momento. Tanto teóricas quanto práticas e como pessoais. Então sei lá... A gente escreveu, escreveu falando... tentando encaixar o conceito, mas antes do conceito a gente teve que falar da nossa experiência... Por que não existe outro caminho. Pelo menos para isso que a gente faz não existe outro caminho. Todos os trabalhos que a gente tentou fazer aí - e eu o Maurício e a Márcia a gente tentou fazer muitos trabalhos da graduação desde que a gente começou a FEBEM, tema livre para gente é a FEBEM - e aí tem que explicar, tem que explicar o que é que a gente faz, como é que eu me porto, para daí virar e falar olha "Nesse trabalho, com essa disciplina, eu posso falar disso, disso, disso" Eu lembro que quando foi do Gilberto, a gente fez, nós três fizemos um trabalho sobre a FEBEM explicando o que é que a gente fazia, o que é o Plantão, da onde ele nasceu, qual que é a nossa prática, não sei o que lá... E aí, falamos: “Ó, dentro dessa prática o conceito que a gente conseguiu achar foi 'os três tempos', 
aquele negocinho do bebê, então você vai ter que... você se aproxima aos poucos, você tem que dar um tempo para pessoa, esperar o tempo da pessoa para cada menino se acostumar com a gente como pessoa e para gente se acostumar também com aquela dinâmica maluca...” Que é que nem o caso Dora: ele relata o caso e depois explica, depois ele vai lá e fala ó: “Acho que tal passagem tal conceito”... Daí, mesmo você estudando, dentro de uma teoria mais ampla... você acaba construindo uma teoria sua tipo: "Você atendendo”... Por que autor, é você que lê, você que faz os recortes.

Que nem a Letícia: dentro de Freud, ela pega mais o inconsciente, porque é o conceito que ela curte, é o conceito que ela ensina. Eu comecei a FEBEM... e depois eu fui para outros projetos... para mim é uma passagem de nome... comecei a ir agora para o Tatuapé e para a Rede de Saúde... Então, o plantão soa muito para mim, e atenção, soa para mim como muito uma coisa de atitude: você está lá dando margem para que um atendimento aconteça... isso que a gente proporciona é dar margem para que a pessoa chegue até você independente de ela pedir para ser olhada ou não. Atenção é assim a partir do momento que você está lá com esse olhar, com esse objetivo, com essa intenção, você já está em atenção... Então... Meu trabalho é atenção psicológica, entro no pátio me porto de determinada forma e, se eu enxergo um menino sozinho chorando, eu me dirijo a ele: "Se você estiver a fim de conversar, estou aqui" É... uma postura atenta. Plantão me dá muito mais a impressão... Quando eu penso plantão me vem proto-socorro na cabeça e aí me vem o hospital... o médico ali e o doente chegando. Mas o doente tem que chegar. O peculiar do que a gente faz é que a gente vai... Até lá. E de repente se a pessoa está doente ela está super feliz: não precisou ficar doente, não precisou sofrer para eu vir até você. E principalmente não precisou ir até o lugar que você está, ali resguardado. Enfim... com um monte de outras coisas, sei lá. Então... Você ir até lá, na hora de você compreender aquilo que você faz, muda algumas coisas, assim... 
Bastante, eu acho. E eu acho que uma coisa que fica na minha cabeça desde quando eu fiz escolar... Então... Com escolar é mais fácil de explicar. Se você recebe uma criança com... para fazer psicodiagnóstico. Então você fala assim para ela: "Olha, eu quero...você recebe cinco vezes aqui na minha salinha, a gente faz tais, tais atividades e depois eu passo um relatório". É uma coisa. Você tem uma visão da criança. Se você é... faz ir até a casa da criança, vê a criança na escola, se vê a criança em diferentes lugares ocupando diferentes posições... Você vai ter uma idéia total da criança. Você está lá na FEBEM. Se você recebe um menino aqui... Primeiro que você vai ser engambelada facilmente por ele, por que ele vai usar uns discursinho todo construído e estereotipado, então... Você já entrou bem... Você já se deu mal... Por que você vai começar a acreditar...

Por exemplo, quando você conhece um menino da FEBEM o menino vai ter que discurso, para você? Vai falar: "Ah, já sei, a hora que eu sair daqui eu vou mudar de vida, eu vou... começar a trabalhar, comprar minha casa, casar, arrumar uma namorada, casar ter filhos...” Você vai sair super feliz: “Que bom!”. Vai ser aquilo que você queria, beleza. Você se deu mal nisso, por que eu acho que você está criando uma expectativa que é falsa de uma coisa que é falsa... Que vai ficar sem conhecer a pessoa... a pessoa dele, assim por que ele acha que você vai avaliar. Você não vai avaliar, só que você não vai ter nem chance de dizer isso para ele. Então às vezes ele tem um monte de outras coisas que ele quer te dizer, que ele não vai te dizer nem se dar a conhecer por ele. O atendimento não acontece... Fica um trabalho meio... burocrático. Ele vai sair, está pronto para sair, sabe, é uma coisa meio avaliativa: "Ah, ele veio aqui e me disse que, quando ele sair, vai arrumar um emprego. Então, pronto." Burocrático. Eu fico sem saber que sentido teve o crime para ele, que sentido tem essa saída, que sentido teve essa permanência para ele. Se você vai para instituição... Se você está lá, você vai ouvir que esse discurso... O quê que acontece se eu for lá: eu indo lá, 
primeiro que eu vou ter uma noção da instituição, que é essencial no caso desses meninos, $e$ eu acho que em outros casos também, mas desses meninos que é o que eu sei falar... Eu preciso ter uma noção da instituição, eu preciso ter uma noção desses discursos todos que permeiam essa instituição. Então: como é o comportamento deles lá, como é o que eles têm como regras, o que eles têm que obedecer, o que eles não têm que... Qual é a postura dos funcionários, como é essa dinâmica dessa casa. Então, eu indo lá, eu vou conhecer isso, e aí, a partir disso, conhecer o menino.

E aí, eu acho que também vai me dar a chance de romper com esses discursos todos, $e$ eu vou falar: “Ó, você está me falando que você vai trabalhar, mas o outro também me falou, hein. Acho que vocês tão querendo me... me tirar.” Por exemplo: atendendo-os, e muitos deles lá, você começa a aprender que o crime tem coisas bacanas. E aí você vai começar a poder jogar isso para eles: “Ó, mais eu sei que a adrenalina é animal, hein. Você vai abrir mão dessa adrenalina? Eu sei que em um roubo você consegue mil reais. Você vai abrir mão desses mil reais?” E eles vão dizer: "Essa mulher aí sabe o que ela está falando”.Eles te recebem de outro jeito quando você vai lá. Ou você dizer: “Eu sou boy, não precisava estar fazendo nada disso, e gosto de ir”. Isso faz com que eles dêem mais valor, me respeitem mais, e aí se abram mais.

A partir do momento que você vai lá... A atenção já é sentida de outra forma... Essa atenção aparece. Por que... Eu estou pensando assim... Quando a gente está doente, por exemplo, qual que é a sua atitude: você ir até o médico. Eu estou com dor de cabeça, vou até o médico... Mas não é muito gostoso quando você está com dor de cabeça e sua mãe, que seja, te dá um chá? Mesmo que a sua dor não vá passar, é uma delícia... Sua mãe vem, te dá um chá, e ela cuida de você. Então ela vem até você numa hora que você está sofrendo e cuida. Para o menino, tem essa diferença... E, para mim, eu não sei se tem grandes diferenças na 
minha postura, mas tem uma diferença de leitura... Acho que é uma postura mesmo, essa postura de abertura: eu vou receber bem, sem julgar, acho que é o primordial... A gente aprende a não julgar... Então por mais que eu tenha meus valores, eu vou pô-los em suspenso e vou ter que escutar os valores do outro, para tentar entender... Afinal eu sou uma pessoa a serviço daquela pessoa. Eu estou na disponibilidade total. Eu não vejo assim super diferenças de postura nem nada. Então, eu vim da FEBEM e a partir do momento que eu fui falando da minha experiência, através dos trabalhos que era feitos em faculdade, eu fui entendendo de outra forma... Depois, vai piorando... Por que você vai ficando com mais perguntas...

Então, eu procuro muitos interlocutores E vou muito atrás do Renato e da Letícia por que eles não são a Helena Procuro contar muito para outras pessoas, que não fazem o que eu faço, que não tem a mesma linguagem... Para poder me questionar. Para eu ir desconstruindo e reconstruindo... Para eu ir entendendo. Eu vou tentando fazer ressoar para mim, da mesma maneira que vou fazendo ressoar para o menino... para ele se entender. Eu tenho que me ouvir falando, tenho que encontrar o que eu digo, para poder construir... Mais ou menos o que é aquilo que eu faço. Ou então eu escrevo: eu escrevo muito assim, eu acho que eu sou a pessoa que mais faz diário de bordo do mundo... Que eu escrevo muito, muito, muito... Eu escrevo, eu relato todos os atendimentos, aí depois eu penso neles um por um... É todo um trabalho bem suado... Mas é por que eu preciso conseguir explicar o que eu faço... Essa necessidade surgiu... para conseguir ter interlocução. Eu vejo pelo Maurício, que corrige os meus diários, é ele que lê os meus diários. E ele fala que ele vê diferenças absurdas entre os primeiros diários e os diários de hoje, que hoje eu consigo construir mais teoricamente as coisas... Eu consigo explicar mais do que antes ou consigo pelo menos formular as minhas perguntas.

Então... Por exemplo... Uma das perguntas que eu consigo formular agora é qual é a 
noção que existe de adolescência ou personalidade, por que... Vamos ver o que é que cabe ali. Não posso, por exemplo, ler o adolescente infrator como um ser de função... Ou explicar por Klein... Não deu. Eles explicam muito bom e mal e não existe bom e mal ali. Bom e mal é tão... Não é suficiente, não é minha praia, não é o jeito que eu quero ver... Agora eu estou estudando Lacan. Bastante. Para ver se eu consigo jogar ele fora. Por que eu acredito que não seja suficiente. Pelas pessoas que... que estudam Lacan. Mas como eu nunca estudei, bom vamos ler lá o cara para ver o que é que ele me diz dele mesmo. E aí, tem uma coisa que me incomoda muito, por exemplo, na aula que eu faço de Lacan que é essa postura de dono dum saber... Sujeito suposto saber. Sabe, se... E não é suposto coisa nenhuma! Eu lembro muito bem, uma vez a Letícia me falou: “Olha pessoas de Lacan falam sujeito suposto saber por causa disso: eles sabem, eles acham que eles sabem." E uma outra coisa que me incomoda muito é você se oferecer como objeto para... para o seu paciente. Objeto passivo. Você não é objeto passivo coisa nenhuma, você é cheio de a prioris, você é cheio de pressupostos. Você vai ter que ser você, é você-psicólogo. Você não vai conseguir ser só psicólogo...

Então essas coisas incomodam, e eu vou ter que destrinchar... Por quê que elas me incomodam... Aonde é que eu acho que está errado e para isso eu vou ter que estudar por quê que elas estão certas. Então, para você ir compreendendo, você também precisa ir construindo um modo de se ver psicólogo, e aí tem muito a ver com o modo como você percebe o outro e você mesmo... E acho importante também buscar... Coisas que falem desse jeito. Lacan não serve para mim como pessoa, não bate com o meu jeito de ser profissional. Eu gosto de aprender, mas eu gosto de saber que eu posso ser eu mesma ali atendendo por que eu sou eu mesma atendendo... Eu não sou uma tábua rasa que de repente alguém se... usa de espelho, eu não sou espelho, só sou espelho segundo determinadas coisas minhas. Vem da sua sensibilidade, que você mesmo coloca na hora e a partir disso você dá nome. De ir 
descobrindo tanto o que é um atendimento quanto como é que você atende.

Que nem quando a Helena foi explicar para uns alunos o Plantão... Na hora que eles voltaram para a supervisão, a Helena falou assim: “-Ah, então vamos lá. Vamos conversar agora: o quê vocês diriam para o cliente?” “-Ah, não sei." “- Mas o quê você achou dele, o quê ele quis dizer aquela hora?” “- Ah, não sei, não sei...” E aí sai. Aí, você fala, por exemplo: “- Ah, ela estava, sei lá, ela estava tão confusa” "-Por quê que você não falou?” “-Ah, eu vou falar para ela que ela estava confusa?” “-É...”. São umas coisas pequenas que você sabe, que você sente e que você não fala... Essas coisas que você fala... Coisas pequenas... São de experiência do humano... Você sabe quando seu amigo está mal. Eu lembro quando a Silvana estava me explicando plantão, por que eu nunca tinha dado plantão na vida: “- O quê que é plantão?” “- Sabe quando você vê que eu estou chorando, senta comigo no banquinho e fala '- Fala aí?’ É isso que é o plantão: você vai falar '- Fala aí.’” “- Ah, então tá. Então é isso.” Por que é essa postura de “- Olha estou aqui cuidando de você estou afim de te escutar, estou afim de... Pode chorar no meu ombro, vamos dividir essa tristeza." Depois essa diferença de conceito, da sua vida e o que você vai vivendo como profissional, você vai construindo devagar. Claro, também, não é uma coisa que... Você não vai poder falar: “- Chuta o cara. Você brigou com seu namorado, chuta ele. Vamos sair para a balada." É outro tipo de relação, e ele percebe as próprias saídas dele. Pergunta... Pergunta muito: “- O que você acha que dá para fazer com isso aí que você está sentindo?” As pessoas tem suas próprias saídas, elas que não percebem.

É como se, no atendimento, ao invés de simplesmente falar, você vai deixar aquilo entrar para devolver o dele. Imagina uma gosma, a pessoa que vem ser atendida está uma gosma, ela não consegue entender nada do que está acontecendo, é uma coisa meio de passagem é meio assim, a pessoa entra, ela entra em você em alguns lugares... Isso ressoa 
junto com o seu e você separa: meu, dele, meu, dele, meu, dele... Aí você se sente autorizada a dizer para ele o que é dele... Eu fico pensando por exemplo na 16. Eu entrei ali e eles jogaram uns medos que eu não consegui dar conta... Eu respirei, separei, devolvi, respirei, separei, devolvi, mas sobrou. Às vezes você devolve e não é suficiente, aí você procura a supervisão... Vai falar do seu medo, dessa sua impressão desse seu negócio, dessa gosma que agora é sua. Então... Você vai falar e a supervisão vai te ajudar a separar... O que é dele a gente trata na supervisão. O que é seu você vai para sua terapia e trata. E a supervisão vai fazer isso comigo... Do mesmo jeito que eu faço isso para o cliente. 


\title{
7. Análise: construindo uma possível compreensão de sentido
}

\author{
Eu tenho à medida que designo - e este é o esplendor de se ter uma linguagem. \\ Mas eu tenho muito mais à medida que não consigo designar. A realidade é a \\ matéria-prima, a linguagem é o modo como vou buscá-la - e como não acho.
} Mas é no buscar e não achar que nasce o que eu não conhecia, e que instantaneamente reconheço. A linguagem é o meu esforço humano.

(Clarice Lispector, A paixão Segundo G. H., RJ: Francisco Alves, 1995 )

A análise dos dados foi realizada com base na proposta de CRITELLI (1996) de realização de um diálogo com os depoimentos, buscando o sentido do relato, que possibilitou uma melhor compreensão da forma pela qual os alunos foram compreendendo as práticas em instituições. Essa busca do sentido dos depoimentos se norteou pela análise da manifestação do sentido que têm as formas de compreensão, pelos alunos, através da prática, dos modos de fazer que orientam as práticas clínicas nas instituições em que participam, seus movimentos de aparição, realização, objetivação e a forma pela qual estes alunos lidam com estes modos de ação.

Considera-se, para tanto, que a manifestação deste sentido, ou seja, do direcionamento para o qual os sujeitos se norteiam a partir dos modos de compreensão que tecem acerca de sua prática, dá-se através da linguagem, relatada pelos depoimentos. Essa manifestação do sentido revela, assim, o modo pelo qual os participantes cuidam de ser aquilo que fazem e que compreendem, o que estes estão fazendo e compreendendo e o modo pelo qual lidam com esse cuidar.

Nesse sentido, a análise buscou compreender as formas através das quais o direcionamento dos modos de compreensão da prática se manifesta. Dessa forma, adotou-se uma perspectiva clínica, buscando percorrer e circunscrever seu sentido, atentando para a aprendizagem a partir da tecitura de um diálogo com os relatos. Este diálogo é articulado a 
partir das possibilidades de compreensão presentes no relato em sua interface com o olhar clínico. Como relata MORATO (1989)

“O fato é que não ouvi as gravações. No entanto, ouvia atentamente o que me falavam os professores dos cursos que fazia, o que falavam os autores lidos e as discussões com colegas. Não exatamente as suas palavras, mas como aquilo que eu entendia de suas palavras ajudava-me a encontrar um caminho para puxar o fio de minha pesquisa” (p.132)

Criando, assim, novas possibilidades de aproximação com os relatos e o tema de pesquisa e tecendo uma leitura e uma compreensão. Nesse sentido, pode-se compreender a construção de sentido como um discurso tonalizado, poético, se considerarmos que " $A$ comunicação das possibilidades existenciais da disposição, ou seja, da abertura da existência, pode tornar-se a meta explícita do discurso poético” (HEIDEGGER, p. 162, apud NUNES, p.110, 1999)

Ao dialogar com o depoimento aqui colhido, percebe-se que este apresenta, em si mesmo, um percurso de construções, desconstruções e retomadas em relação aos temas presentes tanto no fazer clínico quanto nas formas de compreensão deste fazer e suas construções. Realizando um movimento em espiral, a depoente circula sobre os temas pertinentes à prática clínica e seu processo de aprendizagem, aprofundando ou reinterpretando determinados aspectos cada vez que aborda um tema.

Primeiramente, a depoente se remete à sua historicidade, localizando em seu percurso acadêmico e vivencial o estágio de Plantão Psicológico sobre o qual fora questionada.

“E aí começou o plantão no LEFE... no segundo semestre 
do quarto ano. Começou o plantão na USP também, de Aconselhamento Psicológico ${ }^{12}$... (...) No quinto ano, (...) comecei a fazer iniciação com diabetes (...) e continuei fazendo a FEBEM, continuei atendendo uma criança no Individual $^{13}$, continuei fazendo plantão... e as matérias normais... Formei-me e prestei mestrado, aí no começo desse ano eu estava... com o atendimento da criança ainda no Individual, aí continuei na FEBEM, comecei o Tatuapé $^{14}$, comecei a Rede ${ }^{15} \ldots$ E... Ah!! E eu já tinha começado em Pirituba ${ }^{16}$ no semestre anterior (...)Eu mantive um monte de FEBEM, na verdade.”

Neste resgate de sua historicidade, a depoente circunscreve a construção de um percurso de formação e se apropria de seu direcionamento para a prática em instituições ao longo de seu percurso. A própria depoente explicita em seguida esta construção de um sentido para sua prática, sentido este imbuído de uma afetação.

"E acho que não foi à toa... Eu ia fazendo as coisas e ia vendo diferenças, dessas outras coisas que eu fiz para o estágio nas FEBEMs, no LEFE... Os estágios no LEFE acabaram me direcionando... Por que eu ia sentindo, no começo...”

\footnotetext{
${ }^{12}$ Disciplina do sétimo semestre (Aconselhamento Psicológico I) e oitavo semestre (Aconselhamento Psicológico II)

${ }^{13}$ Atendimento Individual, modalidade de Prática Clínica do Projeto de Atençãoo Psicológica à FEBEM/SP.

${ }^{14}$ Plantão Psicológico no Complexo Tatuapé da FEBEM/SP.

${ }^{15}$ Rede de Apoio em Saúde, projeto de integração clínica entre instituições de saúde visando uma rede de encaminhamentos entre instituições.

${ }^{16}$ Atendimento Individual no Complexo Pirituba da FEBEM/SP.
} 
É sobre esta afetação e suas implicações que a depoente fala a seguir. Ela resgata o modo como foi sendo afetada pela prática. A princípio, percebe-a como uma perda de referências desalojante, na qual os significados já construídos anteriormente não contemplam a experiência que se desenrola. Assim, desvela-se na historicidade relatada um momento de crise em seu sentido etimológico, no qual há uma perda de referências que orientem um caminho a seguir, já que as referências até então construídas não se mostram pertinentes ao contexto vivido.

Quando a gente começa o estágio de plantão no LEFE, tentamos colocá-lo nas coisas que já conhecemos... e vai dando encrenca. Não dá certo com uma série de outras coisas.”

Quando você começa a estudar como é que se atende, você estuda conceitos como transferência, contra-transferência, a entrada da pessoa na sala, tal, e você começa a ter um monte de a prioris, e esses a prioris na maioria das vezes são derrubados nos estágios que a gente faz. No Plantão, na instituição, não tem como você ficar... não tem como você garantir uma posição de hierarquia com a pessoa, enfim. Um monte de coisa derrubada.

Esta questão se apresenta também no segundo depoimento, destacando o momento de crise em seu aspecto de não saber

Acho que, quando apareciam coisas que eu tinha, acho que invariavelmente você vai com uma expectativa, acho que quando apareciam coisas que se enquadravam nessa 
expectativa, elas... Tudo bem. Agora, quando apareciam coisas que não se encaixavam, eu acho que é aí que essa aprendizagem começava.

A partir desta vivência de crise, a construção de espaços de diálogo nos quais se possam reorientar e tecer as experiências, mostra-se como eixo referencial que sustenta a reconstrução de sentidos, permitindo “deixar fluir” novos significados e interpretações, ou novas articulações entre concepções já construídas.

E acho que o que mais me faz entender... São as conversas, tanto com a Helena, ou com o Luciano, que são meus supervisores, quanto com meus colegas... Em conversas na supervisão... da aula... Tem umas discussões que a gente tem, ou tem um trabalho que a gente faz... Com a Helena... são as supervisões. ... discussões... de qualquer tipo... Com meus amigos... conversas, no geral... Conversa sobre o trabalho... Conversa quando sai do plantão, começa o plantão... Ou quando... se encontra e encontra um texto...

Eu lembro de uma supervisão... de uma supervisão que eu assisti do Tiago (...) e depois eu vi ele dando supervisão para outras pessoas e aí, a partir do jeito como ele trabalhava, eu percebi que eu trabalhava daquele jeito também e aí... comecei a me identificar. (...) Que significado uma pessoa faz, que sentido tem o que ela está falando, e não... Não se prender ao que ela está falando, tanto, mas... ao caminho que ela fez, assim... E fora isso, 
nós, juntos, acabamos esclarecendo essa história de voltar para o plantão e... marcar retorno... e de fazer encaminhamento. Que horas que o outro faz o encaminhamento... (...)

Mesma coisa com o Marcos, a gente estava conversando... com... A técnica, lá (da FEBEM) de Pirituba, e o eu ouvi explicando o que era o plantão, aí me esclareceu um monte de coisas. Porque lá em Pirituba eles fazem um negócio que chama sensibilização para atendimento, a aí eles ensinam, assim... para o... para o menino o que é um atendimento... "Ah, então atendimento, você vai lá e fala o que você quiser e... sei lá, a pessoa não vai fazer relatório e etc...” Eles informam... Daí quando ele fala “'Ó, então, $e$ no plantão eles vão experimentar..." E aí, como que essas duas coisas tinham que trabalhar juntas... Tanto a informação quanto a experiência, assim... do adolescente, para ele vir a ser atendido. Eu fiquei pensando que precisavam existir as duas coisas mesmo.

Dessa forma, o espaço para falar e ouvir torna-se o eixo no qual novas construções de sentido podem ser realizadas. Há, neste sentido, uma constante reconfiguração, tanto no que se refere às experiências às quais a depoente se remete quanto à forma de expressão da fala no próprio depoimento. Esta reconfiguração é expressa pela depoente, emergindo a importância da abertura de novas perspectivas, possibilitada pelo desalojamento sentido, como ponto de partida para apontar olhares mais pertinentes para a construção de espaços de diálogo. Dessa 
forma, antes de discorrer sobre o espaço da fala, a depoente afirma:

"E então você vai vendo que é preciso ter uma postura diferente, que o que importa é sua postura...”

Nesta reconfiguração, o primeiro "lugar” ocupado pelo espaço de diálogo sobre a experiência, como demonstrado nas citações anteriores, é o de identificação: perceber a própria ação clínica caminhando em um sentido pertinente a um grupo, e construir pontes de articulação entre suas compreensões e as de outros. Este é um momento em que a escuta de outras experiências toma lugar como uma expressão da própria experiência, na qual a depoente reconhece, em outros, o próprio modo de ser e fazer. Ouvir a experiência de outros que também dizem respeito à própria experiência se mostra como um se ouvir na experiência de outros.

Na medida em que as vivências e seus espaços de elaboração se configuram, novas articulações vão se fazendo presentes, reconfigurando os espaços de compreensão da experiência e a própria prática. Da mesma forma, novas práticas vão desvelando novas possibilidades de compreensão. Neste sentido, a depoente expressa outros momentos de crise, nos quais a necessidade de uma constante retomada das próprias perspectivas se manifesta. Dessa forma, circular sobre os diferentes contextos do fazer refere-se também a uma ampliação e rearticulação da bagagem vivencial de modo a reconhecer especificidades e aproximações das formas de a prática clínica mostrar-se em cada contexto. Tateando espaços fronteiriços através da diversificação dos contextos, a depoente também re-circunscreve seu próprio espaço.

A hora que eu mais entendi mesmo foi no começo desse ano, depois de um tempão de discussão, quando a gente começou a ter o curso, quando a gente começou a estudar 
teoricamente, teve as discussões... E eu tive que ler, eu tive que me deparar com os outros projetos, que eu não conhecia, e aí eu tentava estabelecer algumas semelhanças...

Percebe-se no depoimento que, num primeiro momento, o espaço de diálogo se configura como um espaço de escuta para ir se tornando, através do exercício cotidiano deste espaço, um lugar de fala de sua experiência, no qual se constrói a pertinência a um grupo e a uma forma de ação clínica. Através da tecitura de uma compreensão possibilitada pelas “conversas”, a depoente começa a articular diferentes experiências clínicas considerando-se seus espaços de aproximação e entrecruzamento. Neste sentido, a depoente ressalta a necessidade de um olhar cuidadoso, próprio da prática clínica, se compreendida como um inclinar-se para o cuidado no encontro.

Você precisa de um supervisor de campo no campo, você precisa de uma figura de referência, as pessoas precisam de uma figura de referência fora desse campo também, então...(...) E eu só atendi com a Magali porque eu sei quem está atrás de mim, que é o Marcos e que é a Sabrina, que eu posso confiar tanto, tanto, tanto... E que dão, me... Me suprem de cuidados, e eles só conseguem fazer isso porque a gente é uma equipe, e que vai suprir um ao outro de cuidados e assim por diante(...)

E fora as pessoas terem a necessidade de terem espaços para falar, que... Toda hora me grita isso. ...Que só precisam de cuidado e precisam de espaço para falar e 
serem ouvidas(...)

Este lugar ocupado pela fala acerca do vivido, a partir da própria experiência da depoente, vai se tornando, também, lugar privilegiado por ela no atendimento clínico. A perspectiva acerca da prática vai se transformando, com um destaque maior também para a aprendizagem através da experiência do cliente, em detrimento da simples informação. Neste sentido, o lugar do psicólogo vai se configurando também como lugar de escuta e articulação da experiência daquele que é atendido.

Se ele experimentar, ele vai saber, aí vai ficar claro, mas se ele não experimentar, ele não vai saber, e não vai adiantar eu falar... Pode ser que ele não... Não signifique nada para ele eu falar olha, eu não faço relatório... Agora, se ele experimenta e ele vê que eu não faço, aí pronto, eu não faço e... ele pode falar sobre as coisas que ele quiser(...)

A depoente articula estreitamente a possibilidade de dialogia no atendimento clínico à abertura para perceber o contexto daquele que procura auxílio psicológico, relacionando o ato de conhecer a uma percepção não apenas daquilo que é dito, mas de todo o desenrolar do encontro com o outro. Na perspectiva desta percepção, o questionamento mostra-se pertinente, instrumentando a intertroca no encontro.

Eu sou muito mais a favor que tudo comece fora de um setting tradicional e que depois se configure uma demanda e que ai se configure uma psicoterapia do que jogar direto a pessoa na sala e aí tentar fazer com que ela descubra a 
demanda dela... Então tem essa diferença de...de setting, tem a diferença de postura, então a gente não fica quieto, a gente intervém...

Esta atitude de abertura é também percebida no próprio modo de apresentação da prática para a depoente, no qual o primeiro recurso alçado é sua percepção acerca da vivência, já que não lhe são apresentadas referências já construídas para a compreensão daquilo que será vivido na instituição.

Por que aqui eu não consegui encaixar meus guias no estágio? Acho que, primeiro de tudo... A gente começa com o estágio. A gente não aprende nenhuma teoria antes de ir para o Plantão. Pelo menos eu não aprendi... A gente começou a dar plantão seis meses antes de ter a teoria... E... aí tem muito a ver... com o que eu faço... que é atender na FEBEM... Que é outra realidade, os meninos pensam... Eles passam coisas que eu não passo e pensam coisas que eu não penso ...

Este tema também se apresenta no segundo depoimento, no qual o depoente relaciona o posicionamento dado à vivência a um enfoque dado para a inter-relação ensino-aprendizagem.

Eu acho que era bem mais fácil por que era uma prática voltada para o ensino e essa prática que eu comecei a participar no projeto estava muito mais voltada para aprendizagem e eu acho que nesse sentido... Quando eu 
falo da prática que eu tinha na graduação enquanto ensino é por que ela já estava toda balizada por onde deveria seguir, então você tinha uma série de... de ganchos, é... na determinada disciplina, no curso... Que você voltava essa experiência para um determinado fim já.... Já pressuposto, então... Você vai atender... Métodos, que era uma disciplina, você tem que fazer um psicodiagnóstico, então já tinha um fim em vista, já tinha um horizonte em vista, é... Depois a outra experiência clínica que a gente teve era... O SAP, e tinha um atendimento, mas também já estava em vista de que tinha que ir até o encaminhamento, ou que só ia ter determinados encontros e de que tinha a ver com você apreender as atitudes básicas do Rogers, de você estar sendo balizado por isso... Então, essas práticas... Elas estavam enquadradas num contexto de ensino. Quando eu digo que eu entrei nos projetos e que era uma questão de aprendizagem... Foi que eu não tinha um norte definido de onde eu deveria chegar e as coisas que iam surgindo elas iam sendo apreendidas para mim $e$ iam mudando esse horizonte Se eu tinha uma perspectiva onipotente, aquilo logo foi para o chão... Então acho que nesse sentido... Na graduação era muito mais fácil eu entender o que eu estava fazendo por que tinha... esses artifícios. No projeto, foi uma coisa que não me foi dada, 
foi uma coisa que eu tive que criar. Coletivamente? Sim, coletivamente, não foi uma coisa de criação solitária, mas é... as pessoas também estavam buscando essa sua própria construção.

Falar e ouvir acerca da experiência vai possibilitando, aos poucos, uma abertura para novas formas de compreensão, que abarquem o vivido e possibilitem um resgate de sentido. Ao mesmo tempo, possibilita um espaço de acolhimento e troca de referências, de modo a tecer articulações entre as sensações internas e o contexto vivencial. Nesse sentido, novas referências vão sendo construídas. Porém, elas não se colocam mais a partir de conceitos, mas se mostram como uma abertura para compreensões possíveis, que se constituirão a partir da relação com o outro. Desse modo, as referências se expressam como uma abertura para deixarse afetar pelo outro e para afetá-lo de alguma forma construída no próprio diálogo - como atenção para o espaço intersubjetivo em sua diacriticidade.

Primeira coisa: eu não faço relatório, então, eu garanto sigilo absoluto e isso faz parte do meu... dos meus " a prioris" e eu vou... Carregada disso. Eu não faço relatório, então, meu sigilo está garantido. A outra questão é: eu me respeito, então... Eu não vou passar do meи limite. E eи vou respeitar o outro. Nesse caso, o adolescente que vier até a mim. E aí, eu espero que... O vice-versa aí aconteça, e então ele se respeite, ele não vá passar dos limites que ele não quiser, e também não vá me cobrar que eu passe dos meus, e aí se cria um respeito mútuo. E a outra coisa que eu acredito é que "a priori" a 
gente confia muito. Então... Eu tento... Não generalizar nada...

“Então, "a priori”, eu vou confiar e... Eu confio em nossa relação, em nosso vínculo que vai se estabelecer... E no começo isso é uma crença, porque... Como é que eu vou saber se isso vai acontecer mesmo? Mas é um "a priori”... Uma coisa meio assim, de “mergulhar”... Eu, eu vou, eu me entrego... E me entrego inteira...Me abro... E falo “Olha... Vem aqui, e vamos conversar...” E aí eu sei que eu espero... Que essa relação se estabeleça, que esse vínculo se estabeleça(...)”

Este espaço para o diálogo acerca da experiência não ocorre de maneira dada, mas vai sendo construído ao longo do fazer, através da possibilidade de abarcar o desalojamento como implicado no movimento de busca de sentido, como abertura para o fluxo da experiência em sua multiplicidade de compreensões possíveis, tecidas no diálogo. Dessa forma, a depoente passa a relatar situações em que também fala acerca de sua experiência, na qual tem a abertura para significados e sentidos a serem construídos com o outro como perspectiva. Além disso, esta perspectiva se faz possível através da percepção da existência de uma inabarcabilidade do real em si mesmo, dando legitimidade às compreensões possíveis de serem articuladas nos espaços de diálogo - a construção de uma compreensão com o outro vai se fazendo possível a partir da percepção de um vazio desalojante, de um “algo” que não está compreendido.

O que eu mais... discuti com o Marcos, faz umas duas semanas que eu estou pensando nisso, assim... É que não existe causa-efeito... não existe... "Se eu fizer isso vai 
acontecer isso com certeza”. E é isso o que mais me incomoda nas teorias em geral, assim... Quer dizer... Você não tem um... um fim específico. Você pode até esperar que algumas coisas aconteçam, que nem eu falei "Olha, então eu confio no menino e acredito que possa acontecer de ele nunca entrar para a rebelião”... Só que... Se me pegam... de repente... o que eu posso fazer? Por que... o "sim", então...não existe. Quase nunca... É muito difícil fazer alguma coisa e prever um resultado... com gente... não dá... É... num humano, é muito difícil... Não dá para você generalizar e dizer que está tudo muito claro...

Ao remeter-se à perspectiva de crise, novamente a depoente reconhece uma transformação interna referente a seu modo de olhar, ao mesmo tempo em que percebe seu percurso e sua perspectiva anterior.

Mas... em outras... experiências minhas eu conseguia fazer isso... O que mudou? Eu acho que uma das coisas que mudou foi o meu jeito de olhar a situação... Por que... Por exemplo, mesmo no LAP, quando eu fazia estágio com as crianças, que eu achava que a teoria ia direitinho...

Hoje, quando eu tenho a mesma teoria... e as mesmas crianças... São as mesmas crianças e a mesma teoria e o mesmo professor. E eu olho e falo "Puxa vida, ele nunca me prometeu nada mesmo!" Sabe? Ele nunca falou assim "Vai na fé com isso!" Tanto que agora, que eu vi numa 
matéria, ele fala "Olha, tem tantas, são tantas as condições, que você pode oferecer as condições, mas todas as condições são necessárias, mas elas não são suficientes. Então talvez seja isso, talvez eu seja ingênua a tal ponto de acreditar que - sei lá - se eu fizesse uma coisa, eu teria um resultado certo... E não é...

O sentido do encontro terapêutico deixa então se ser direcionado a uma finalidade pautada por conceitos pré-estabelecidos, embora abarque expectativas, para se tornar uma referência que possibilita a abertura para os significados e sentidos a serem articulados no diálogo.

Eu continuo esperando, mas agora espero sabendo que não vai ser possível... (...) Você não pode deixar de acreditar na potencialidade da pessoa que está falando com você.

A partir da reconsideração das possibilidades do encontro terapêutico, a depoente ressalta, em sua aprendizagem, uma valorização do questionamento de sua própria forma de perceber e dialogar com o outro, apreendida agora como matéria prima para as tecituras deste encontro. Assim, constrói-se em seu relato uma perspectiva que tem como horizonte a relação terapêutica em sua multiplicidade.

(...)E... uma das coisas mais gritantes em supervisão, também, de diferente... É que todas as supervisões que a gente tem aqui, tanto na Helena, como na do Luís, como a Vanessa... como as que assisti... Elas perguntam, todo mundo pergunta... "O que é que você sentiu na hora em 
que estava atendendo?” Ou... "Como é que você se sentiu quando a pessoa respondeu isso ou aquilo?...” E você se ter como referência na hora do atendimento é uma coisa que ninguém ensina... Então... O que eu senti só é importante aqui. Em outras supervisões nunca foi. E é o que mais me instrumentaliza... Porque a partir do que eu senti e percebi que eu vou poder intervir...

O espaço de supervisão como um espaço de legitimação das comproeensões sobre a experiência também se mostra no segundo depoimento, no qual o depoente afirma que

Na supervisão, a partir dessa experiência clínica, e isso estar sendo legitimado como... Relevante numa supervisão... E eu poder estar sendo cuidado. Então não só um olhar visando um cliente, ou o caso, mas como essas coisas estavam me afetando... Acho que esse foi o modo como as coisas foram mudando... Acho que teve o cuidado das pessoas em justamente não me atropelar... E de certa forma também estarem dizendo que também já passaram por isso... Ou dizendo que não passaram por isso, que também era valioso... Trocando essas coisas assim eu conseguia... Estar trabalhando comigo essas experiências... Então eu acho que é um trabalho em conjunto, mas também um trabalho solitário... 
A depoente percebe, então, esta perspectiva, expressa em sua forma de dialogar como fundante dos espaços de significação de sua experiência e diferencia o olhar para a relação terapêutica de um olhar para a conceitualização redutora daquele que é atendido.

Uma diferença entre discutir o caso e discutir "eu atendendo"? Acho que tem essa diferença... Uma diferença do jeito como eu estou lá, na situação...

Eu estava lembrando: a minha supervisora também tinha isso de perguntar como é que eu estava no atendimento... Mas era diferente, mesmo assim! Era como eu estava para saber como agir com ele. E aqui não, é como eu estava e que cuidados. É preciso ir comigo para... Para daí intervir nele, e tem esse aspecto de "Ah! Deixa-me respirar $e$ separa 'meu - seu' e... e devolver o que é dele para ele, mas essa preocupação é só quando eu estou aqui.

No relato acima, a depoente ressalta o aspecto de conhecer em seu sentido etimológico (cognoscere: fusão para dar nascimento), e uma possibilidade de tecitura do espaço intersubjetivo no qual os significados são construídos a partir da percepção de sua própria forma de se apresentar nesse espaço. A partir desta compreensão, a experiência ganha novas matizes, passando a ser o ponto de convergência para construção das significações nos contextos de diálogo, tanto na relação terapêutica do atendimento quanto na relação pedagógica das supervisões e discussões com pares, tanto no contexto clínico do trabalho conjunto quanto no contexto educacional dos espaços formais de reflexão. Assim, o experimentar, ouvir e falar do que se experimenta a partir do vivido vai se configurando como uma narrativa do cotidiano da prática, e dessa forma, como espaço de constantes 
ressignificações. Nesse sentido, a depoente vai compreendendo, através desta narrativa, sua própria prática clínica como um espaço para a vivência de um encontro intersubjetivo, no qual o tema é a subjetividade daquele a quem atende, e que aponta para uma interrogação, um questionamento, um “espantar-se” diante do outro e do mundo a partir de si mesmo. O encontro com outros em uma relação clínica - tanto em seu contexto pedagógico quanto em seu contexto terapêutico - vai emergindo como um espaço vivencial e dialógico: espaço para viver a experiência de troca intersubjetiva e, ao mesmo tempo, espaço para elaborar a experiência vivida. Desse modo, ressalta-se uma atitude de abertura que pressupõe um desconhecimento do que se desenrolará no encontro e uma perspectiva da relação terapêutica como algo a ser construído.

... Eu acho que nos projetos que eu participo, e eu acredito que nos outros também, não sei se é tanto a linha teórica que cada um segue ou a abordagem que cada um gosta mais... É mais uma disponibilidade, um jeito de pensar, uma atitude, um jeito de se colocar frente à outra pessoa.

Por exemplo: esse lance de a gente atender fora de um setting tradicional. Tem um monte de gente que é contra... Eu sou muito mais a favor que tudo comece fora de um setting tradicional e que depois se configure uma demanda e que aí se configure uma psicoterapia do que jogar direto a pessoa na sala e aí tentar fazer com que ela descubra a demanda dela...

Nesse sentido, a depoente ressalta uma questão cara à relação clínica: o outro - neste caso, o cliente - se apresenta a partir das possibilidades dadas por seu modo de ser, e seu 
encontro com os elementos do mundo, inclusive o terapeuta, se constrói a partir deste apresentar-se. Assim, a relação terapêutica parte de uma abertura para um interrogar esse modo de apresentar-se. A depoente percebe essa importância a partir da abertura dada às suas próprias possibilidades, percebidas e relatadas nos espaços de supervisão. É nesse sentido que a valorização da própria vivência ganha importância, como eixo no qual as significações são construídas.

Mas eu fui percebendo que precisava ter essa postura ... Acho que pela prática. Desde o começo quando a gente chegou lá... no meu primeiro dia. Eu vou começar a fazer um estágio e aí chego lá e... é um bombardeio de perguntas que você vai ter que responder. Então, para descobrir qual a minha postura, eu fui fazendo, fazendo, fazendo... e foi aí que eu fui construindo a minha postura.

É como se as coisas que você aprendeu não fizessem sentido, então eu tive que construir um outro jeito. E agora não existe mais o jeito de antes, assim. Não consigo fazer de outro jeito.

A partir da própria ressignificação de sua experiência ao longo do depoimento, a depoente resgata seu processo de aprendizagem, ressaltando, como favorecedores de sua aprendizagem, seus momentos de crise e busca de significações para suas vivências. Partindo deste movimento de compreensão, ela percebe uma primeira atitude de busca de conceitualizações e aplicação de teoria, para em seguida relatar a dificuldade sentida para contemplar sua experiência através do conceito.

“(...) Aí você chega lá com os seus a prioris e você vai 
percebendo que isso começou a ser derrubado... E aí tem que explicar, depois... E aí você vai ter que tentar explicar tudo aquilo que você faz a partir de alguma teoria, ou a partir de um... Sei lá, você vai tentar... eu ficava tentando encaixar. Então, sei lá, eu pensava: "Ah, então eu tenho que responder às perguntas deles. Então eu não posso ter uma postura imparcial frente a... frente a eles. Então eu não gosto de teorias que me mandem ter posturas imparciais.”

É também a partir desta percepção que a conceitualização ganha um novo status, atuando mais como espaço de reflexão do que de construção de conceitos rígidos. Nesse sentido, ela se refere à busca de contornos, pré-objetal, ao invés de uma busca por uma afiguração precisa dos fatos ocorridos na relação terapêutica. Assim, a linguagem sobre a experiência se coloca mais como um recurso para a reflexão, que aponta para sentidos possíveis do encontro intersubjetivo, do que a uma descrição precisa e absoluta do fato deste encontro.

E aí foi meio assim, sabe, foi meio fuçando teorias, e ainda não consegui achar... Acho que é como - eu estudo bastante Piaget - como esses processos de acomodação: você tenta assimilar de qualquer jeito, a qualquer custo aquilo que você está vendo com aquilo que já tem."' Só que você vai vendo que não vai dar, então você vai tendo que adaptar aí as coisas... Uma hora, outra hora, assim, e aí você vai tentando uns acordos, você com você mesmo... 
uns acordos com as coisas que você acreditava,

Eu ler tudo via complexo de Édipo, eu sei que tem determinados contextos que isso cabe. Lá, precisa de alguma coisa além disso, eu acho.

Então, a gente tem um fazer que é completamente diferente de um monte de coisas que acontecem... e que a gente não consegue dar nome e que não adianta ficar tentando encaixar por que a gente não vai conseguir. Mas para ir compreendendo isso... ir construindo isso... Na hora que destruiu fui buscando... a primeira coisa que você fiz foi ir buscar a teoria... a primeira coisa foi o que é que explica aquilo que eu faço. E aí nenhuma explicação era suficiente,

A partir deste novo "lugar” da teoria, a depoente se volta para o relatar da própria experiência, agora articulada às compreensões possibilitadas em seu percurso de aprendizagem. Assim, passa a apreender seu próprio processo de aprendizagem. Dessa forma, o transito pela multiplicidade das experiências do encontro terapêutico torna-se a matéria prima para o reconhecimento dos espaços de articulação do sensível e do percebido na relação clínica.

(...) que nem quando a gente dá plantão. Você ensina, você fala: “Ó, então você entra na sala explica para pessoa o esquema, e aí... escuta o que ela tem para falar.” O que vem depois do que... dessa hora, "escuta o que ela tem para falar”, cada um vai ter que aprender. Você vai ter 
que aprender sozinho, você vai ter que ver... Aprendi isso fazendo. Fui lá, fiz, voltei, fiz supervisão, fui lá, fiz de novo, voltei, fiz supervisão... E o que aconteceu...

(...) eu estou disponível, eu estou entregue... Oferecendo um tipo de relação de compartilhar com ele do sofrimento dele...Então eu digo: "Eu vou tentar estar com você... Olha, me dá a sua mão e vamos juntos!”

A compreensão da abertura para o sensível e o percebido comparece no segundo depoimento, em que este tema é relatado como um lançar-se, tanto ao aqui e agora do encontro, quanto na articulação das próprias percepções sentidas do espaço de supervisão.

... Eu tinha que de certa forma me lançar porque acho que aquele grupo podia cuidar daquilo, entendeu? Confiar de que tinha uma equipe, de que não estava solitário, e... E trazer isso para, é... trazer essa solidão, trazer essa dificuldade trazer, é... essa dor de estar aprendendo profissionalmente, de estar crescendo profissionalmente... é... ...de estar aprendendo esse modo clínico, essa modalidade clínica... ...como relevantes para tarem sendo discutidos em supervisão antes... ...de estar só trazendo a uns fazer tal e tal tarefa ou vamos fazer tal e tal coisa... O grupo apontava... O supervisor ou o grupo apontavam para esse cuidado....

Esta articulação do sensível e do percebido que vai se construindo nos espaços de 
diálogo vai possibilitando significar os sentidos percebidos na relação clínica, como forma de tornar comunicável a experiência. Nesta vivência de comunicação como construção, as articulações realizadas deixam "aberturas” nas significações, de modo que a comunicação da experiência é percebida como uma leitura possível, mas também passível de releituras. Dessa forma, a depoente transita para um segundo momento de construção dos espaços de diálogo, no qual há uma valorização do relato ao outro da própria experiência através da legitimação deste relato como busca de significações para o encontro terapêutico.

(...) no começo eu acho que a gente é muito... Muito uma lixeira, assim, sabe, a gente recebe muito, a gente capta muito, sente muito e se autoriza muito pouco a falar. Aí você desce para supervisão e fala: "olha, a pessoa falou isso, isso, isso...” E aí a pessoa que te dá supervisão fala: “mas aí o quê que ce pensou sobre isso?” Você fala: "Ah, pensei tal.” “- Mas você falou?” “- Não, não falei” “Então fala da próxima vez” E aí da próxima vez você vai tentar falar... aquilo que você sentiu (...) Cada vez mais alguém vai te autorizando a falar e como esse alguém você acredita saber mais do que você, você se autoriza também. (...) Por que você acredita que o outro seja dono de um saber maior que o seu. Então... A pessoa tem pelo menos mais experiência. Então ela vai saber mais ou menos se você fez direito ou não. Então, se você achou que fez direito e ela também, então você se autoriza cada vez mais 
a fazer. Assim: a pessoa ia lá e me falava. Aquilo me batia de alguma forma... Só que eu não sabia... Se podia... Devolver isso para pessoa ou não. Aí, quando ia na supervisão, o que acontecia para eu ir compreendendo é que o supervisor começava a dizer... A me autorizar a devolver aquilo que eu sentia...

Eu estava pensando agora... Teve uma aula do Gilberto, eu acho, que a gente fez, que ele falou que... Ele falava assim: que a pessoa espera, a pessoa que vem te procurar, ela está sentindo tudo. Ela sente tudo, e é um bando de angústia. E que conforta você dar nome àquela angustia, então... Ele contou uma história de um menino que estava apaixonado...

E aí eu acho que a gente talvez imagine que as nossas intervenções tenham que ser enormes, sabe, mirambólicas, assim, sabe (...) Você sabe que a pessoa está triste e você não sabe nem se vai falar “Puxa, como você está triste”... Que é uma coisa tão... que parece tão pequena e que para pessoa vai ser tão grande... Acho que essas intervenções pequenas a gente deixa de fazer. Que a gente desconfia que elas não vão ser legais. E aí você está embebida dessa tristeza na hora que você vai para a supervisão. E você não sabe direito o que é que você está sentindo e alguém vira e fala para você e dá esse nome e fala: "Então a 


$$
\begin{aligned}
& \text { pessoa estava tão triste...” E aí você fala: “Puxa... a } \\
& \text { pessoa estava triste.” E aí você fala: “Nossa, então da } \\
& \text { próxima vez eu posso virar para ela e falar: “como você } \\
& \text { estava triste,” }
\end{aligned}
$$

Neste movimento relatado, a depoente ressalta a abertura para uma apreensão daquilo que o outro lhe apresenta, que passa, antes da via cognitiva, pela via da percepção. Assim, expressa-se, implicada no encontro, uma atenção para o “entre”, para o movimento diacrítico do encontro intersubjetivo. Assim, o processo de aprendizagem mostra-se como um movimento de desconstrução: partindo de pré-concepções, abre-se para que estas sejam ressignificadas por uma experiência vivencial, na qual o que é sentido e percebido ganha lugar. São estas percepções e vivências que se constituirão como matéria prima através da qual os significados podem ser articulados, tanto na aprendizagem quanto no próprio atendimento. Para isso, a aproximação teórica acaba por se fazer a partir da própria reflexão sobre a experiência, retomando o que antes era tido como um distanciamento. O movimento de apreensão do espaço diacrítico da relação terapêutica e da relação pedagógica se expressa com mais clareza na fala da depoente quando, após relatar no depoimento sua experiência, ela constrói uma fala que ao contorna:

Como no começo você só recebe, por que você não se autoriza a falar, você desce do jeito que... do jeito que a pessoa estava. E aí na hora que você chega lá e tem a supervisão, a pessoa vai te nomear tudo aquilo que você está sentindo... E aí, pronto: você vai ver que da próxima vez dá para você chegar lá e fazer isso com a pessoa, que vai ser suficiente. 
Esta questão é relatada no segundo depoimento, ressaltando-se o aspecto clínico da supervisão como um debruçar-se para o cuidado.

Como a supervisão foi me ajudando a perceber isso? Ou como foi eu na supervisão percebendo isso? (...) Bom, você poder estar sendo compreendido por outras pessoas... E você estar sendo cuidado por outras pessoas e que aquilo não era uma viagem só sua, aquilo cabia dentro. Então você podia... Trazer por inteiro as coisas que você estava anunciando, porque quando você estava no plantão, quando você estava nesse trajeto, na pressão psicológica, da forma como a gente estava, você não estava lá por inteiro... A gente estava atento, a gente estava numa prontidão que se dava a todo tempo, que não era uma questão de "Ah, eu só vou estar assim quando o fulano vir...” Tinha umas comunicações que, que... Aconteceu o tempo inteiro, mesmo a pessoa vindo diretamente ou verbalmente falar com você.

Esta articulação possibilita à depoente resgatar sua própria fala e possibilidade de interlocução com a fala de outros como eixo no qual um saber pode ser construído. É neste momento que o status das falas - suas e de outros - se apresenta de maneira dialógica: “autorizada a falar”, e ao mesmo tempo embebida do desalojamento expresso na dificuldade de significar a experiência, agora a articulação de sua fala se faz como possibilidade de tecitura instrumentalizada pelo espaço de diálogo. 
Agora eu acho que eu ando muito mais no caminho de entender aquilo que eu faço, primeiro, para depois buscar uma teoria. Construir a minha explicação... Por que... porque eu não sei, eu sempre tive essa coisa de: "Ah, então eu aprendi tal conceito e acho que esse conceito se encaixa com o que eu fiz ali." Só que daí você vai vendo que vai ter umas horas que não vai encaixar, não vai encaixar, não vai encaixar... Então... Puxa, então pára e pensa: "O quê eu faço ali?" O quê eu faço, ou no quê eu acredito, qual é a minha postura, como é que eu me abro, como é que eu me fecho... Enfim... Qual que é o meu movimento, primeiro, para depois eu tentar buscar em algum lugar... esse movimento que eu faço. Por que senão vai ficar uma loucura de teorias, a minha cabeça... Antes o que eu faria seria tentar pegar a teoria e colocar na prática, aí agora eu tento... quando comecei a fazer isso, tive que ir... da prática para a teoria...Teorizar aquilo que aconteceu....

Esta questão apresenta-se no segundo depoimento, em que se destaca o seguinte relato Eu fui passando por um longo processo de como entender essa atenção psicológica que tinha a ver ao mesmo tempo que... com coisas internas e com coisas externas... Acho que uma era entender a proposta é... desse projeto do qual eu participei. A outra era eu me dar conta de certos movimentos que eu realizava nessa compreensão. 
A partir desta nova perspectiva da relação entre a experiência e a articulação de significados para ela, a depoente reconhece diferenças entre as esferas de compreensão em que transita no contexto clínico da atenção psicológica para outros contextos, e reconhece o espaço diacrítico da intersubjetividade como uma esfera de comunicação pré-objetal e não conceitual, na qual o sentido pode ser apontado e comunicado pela fala, mas não pode ser apreendido em sua totalidade. Assim, a constante fluidificação de significados e sentido, a partir do sensível, tendo a fala como instrumento, emerge como âmbito referencial do fazer clínico.

Eu fiz um estágio com criança na época que eu estudava Piaget. Então, você tem ali a teoria... Tá ali, a teoria é clara. (...) E aí, beleza: eu ia lá para o meu estagio, lia as crianças de acordo com essa teoria. E pronto: ia embora para casa, fazia o relatório do que estava acontecendo $e$ estava satisfatório. Combina... Bate. (...) Chega uma hora que começa a faltar coisa, então... Piaget estudou a inteligência, falta a afetividade. (...) Então vai procurar no Freud a afetividade. (...) Eles não se encaixam perfeitamente, como é que você vai fazer para encaixar os dois? Toca estudar para caramba para tentar encaixar um no outro. Nesse estágio não dá para fazer isso (...) Então, a supervisão... Você vai lá pensando um monte de coisas que você não consegue dar nome... ou às vezes até sabe o nome mas não se autoriza a falar. Quando você chega na supervisão, o supervisor de certa forma faz com você o que você vai fazer com o cliente (...) Por que a gente capta 
muito... Eu tenho uma impressão que a gente é tipo um urso... Que vai e abraça a pessoa, capta todo sentimento dela. E depois metaboliza e devolve, assim.

Este tema é abordado no segundo depoimento, expressando presença subjetiva implicada na fluidificação de significado

A apreensão do que era esse projeto, do que ele se propunha enquanto prática clínica e um diálogo com como essas coisas ecoavam em alguns movimentos internos. Eu vinha de uma prática da graduação na qual era mais fácil entender o que eu estava fazendo ali...

A partir da reorientação do sentido da atribuição de significados do vivido, através da linguagem, a depoente passa a rearticular seus espaços de significação, reorientando suas esferas de aprendizagem. Assim, ela destaca aspectos vinculados às significações da vivência pessoal, que transitam na esfera clínica em nível tácito, à prática clínica propriamente dita, como possibilitadora de percepções e significações da esfera intersubjetiva do encontro e aspectos vinculados às significações construídas através da linguagem como possibilitadoras de reflexão e interlocução, consigo e com outros, de forma a circunscrever o próprio âmbito de atuação e construir um sentido para a prática.

Você precisa dar nomes para as coisas que você sente... Primeira coisa, aí seu terapeuta vai ajudar, enfim. Você precisa atender senão você não vai conseguir saber como você percebe o outro. E você precisa estudar por que, meu Deus, você precisa ter uma explicação minimamente científica para aquilo que você faz. Não sei se científica no 
sentido de sei lá, qual ciência, mas uma explicação para poder chegar até uma outra pessoa que desconhece completamente aquilo que você faz e falar para ela: "Olha o que eu faço é isso, isso e isso, e tem esse, esse e esse nomes”. (...) Primeiro para gente conseguir entender... Por que a gente também precisa de nomes para além dos nossos sentimentos. A gente precisa de nomes para aquilo que a gente faz. E depois para ter interlocução.

A partir da reorientação da articulação entre experiência e linguagem, a depoente expressa um resgate do percurso realizado, localizando rearticulações do sentido da prática que aconteceram ao longo de sua experiência, ressaltando a vivência institucional como significativa em sua possibilidade de fazer emergir o trânsito de sentidos como condição da prática clínica. Desta forma, ressalta a rearticulação do locus da teoria a partir de uma perspectiva desta como instrumento para a tecitura de sentido, efetivando o trânsito entre o percebido - tácito - e o significado articulado - explícito - na construção de um saber de ofício.

Mas eu fui apreendendo isso... .Eu não sei, assim, eu vejo transformações em mim. Foram acontecendo ao longo do tempo, então.... Eu não sei, assim...eu vejo por exemplo no começo da FEBEM... Então, sei lá, eu tenho... Uma vida antes da FEBEM e uma vida depois, assim, por que acarretou um monte de mudanças em mim. Então... Eu não sei, eu (...) fico pensando que eu...passei a questionar mais as teorias ...mas é...é fazendo(...) 
Da mesma forma, o âmbito da fala sobre a experiência se reapresenta no depoimento. A depoente passa a relatar sua própria experiência clínica, tecendo articulações entre o sensível, percebido no atendimento clínico, e sua atribuição de significados. Assim, expressa uma compreensão do movimento diacrítico do encontro intersubjetivo e confere legitimidade à sua própria fala como possibilitadora da construção de significações. Nesta perspectiva, a prática clínica como esfera possibilitadora da percepção do sensível - sendo esta a matéria prima para a construção de significados e orientação de sentidos - é ressaltada: construir significados e sentidos a partir das apreensões possíveis no encontro clínico é expresso como uma tecitura cotidiana e constante, constituindo um arcabouço experiencial e tácito que possibilita a compreensão do trânsito do sentido implicado na prática clínica. Situando na pertinência do âmbito clínico a multiplicidade de possibilidades de compreensão, a depoente resgata o desalojamento em sua condição de angústia como próprios das constantes fluidificações de significado presentes na compreensão de sua prática.

Todo mundo já sentiu algum dia solidão. Como é que você vai perceber que o outro está se sentindo sozinho: por que alguma vez já... Você já se sentiu daquele jeito. Na hora que a pessoa fala, aquilo ecoa de um jeito em você e você (...) aprende a falar para ela "Puxa, acho que o que você está sentindo é solidão”. Mas por que eu reconheço em mim, sei aonde me toca e aí eu vou saber, então isso aqui é da pessoa. Agora, para aprender a fazer isso... eu não sei. Precisa fazer muito, assim, eu acho(...) Você não consegue aprender a atender sem atender... muito... sem ser questionado para caramba e sem sofrer muito, assim. Por 
que eu não encontro nenhuma outra via... Um atendimento vai mexer com coisas suas, então você vai ter que se abrir para... ser mexido. Então... isso vai doer. Por que não é... Ninguém vem feliz da vida. Procurar a gente. Todo mundo vai vir ou se sentindo triste, ou se sentindo mal, ou se sentindo sozinho, ou com saudades, ou... enfim. Com esse bando de sentimentos que a gente evita... de perceber... na maioria das vezes... no decorrer do nosso dia a dia.

Dessa forma, a depoente passa a relatar os espaços da fala que tornaram possível a construção de significados e sentidos a partir das apreensões do encontro clínico como forma de compreensão do movimento diacrítico do encontro intersubjetivo. Nesse sentido, o reconhecimento da necessidade de uma compreensão construída a partir de si mesmo no percebido através do contato com o real se articula com a disponibilização de um espaço de acolhimento no qual o diálogo com outros torna possível uma rearticulação das afetações emergidas na prática clínica possibilitando um reconhecimento interno e, por isso, autoapropriado. Neste contexto, a depoente expressa também a percepção de que uma fala apenas exteriorizada não contempla a relação clínica, mostrando-se redutora da multiplicidade apresentada no encontro.

(...) precisei de um grupo muito legal de supervisão, por que a supervisão vai dizer de coisas suas e vai ter que ser um grupo que...que receba bem. Vai precisar de um supervisor que te cutuque de um jeito... legal. Que tem supervisores que só vão discutir o caso e não acho que é isso que tem que ser... Por que não adianta você só saber 
do outro. Você vai ter que distinguir em você o que é seu e o que é do outro. Se o supervisor só vier no que é do outro, (...) não fica completo, assim. Você tem que perceber em você o que é que aconteceu para você saber dizer do outro. Então... para ir compreendendo isso daí eu precisei entender o que estava se passando dentro de mim, na hora do atendimento... Para poder devolver para o outro aquilo que era dele, também... E ao mesmo tempo me autorizar a isso...

Partindo da compreensão e expressão do trânsito de sentidos do encontro clínico, ocorrido a partir da afetabilidade, a depoente aprofunda a questão do trânsito interno desta afetabilidade através das significações construídas e reconstruídas nos espaços de diálogo. Assim, relata seu processo de aprendizagem clínica, no estabelecimento de um movimento transacional do sensível para o nomeado, como dois momentos do trânsito por um sentido. Neste movimento, que se apresenta como uma passagem para a fluidificação de significados, resgata momentos de aprendizagem, circunscrevendo a elaboração da afetabilidade tácita da prática clínica nos espaços de reflexão, a partir de sua própria percepção.

(...) tem atendimentos que às vezes a gente não dá conta...

É por que mexeu em alguma coisa que você ainda não mexeu. Então... sei lá, eu tenho um lance de querer respostas para tudo, mas tem coisas que não têm resposta. Se alguém que eu atendo me mostra isso: "Olha, então tem coisas que você não tem resposta” (...) aquilo vai mexer comigo de algum jeito, vai ser um atendimento do qual eu 
não vou dar conta, e aí... Eu vou levar para supervisão e vai chegar nesse ponto: "Olha, tem coisas que você não dá conta. Tem coisas que você não vai ter resposta”. (...) em outros atendimentos... que antes eu não conseguia dar conta (...) eu lembro ano passado uma vez que eu procurei a Helena por que o menino só chorava no atendimento $e$ eu não estava conseguindo, estava demais para mim. Aí ela falou para mim: "Olha sentimento demais te causa esse mal". Mas me causa, sabe, não é: "Ai, nossa o sentimento está causando um mal na outra pessoa, a outra pessoa não está se agüentando..." Não. Me causa esse mal, vai ver o que é seu aí. Por que daí você pode responder para o outro. Por que às vezes você acha que é insuficiente para o outro uma coisa que você fez, então: a pessoa está chorando muito. Você fica do lado dela, é suficiente. Ela precisa de companhia para chorar. Você vai chorar junto com ela e pronto. Às vezes para ela, está beleza. Mas mexeu com alguma coisa sua. É no seu que você vai ter que ver. (...) Você estava ali do lado da pessoa, você acompanhou o sentimento com ela, sobrou um pouco em você, mas é seu. O que sobrou. Do outro você deu conta ali (...) Se... se você não percebeu o quê que é seu, da próxima vez você não vai conseguir devolver.

A partir da percepção de sua possibilidade de afetabilidade pelo outro no espaço 
clínico, a depoente percebe também a possibilidade de transito do sentido no diálogo entre si mesma e o outro, como possibilidade do estabelecimento do vínculo terapêutico através da multiplicidade de possibilidades humanas presente na esfera intersubjetiva. Assim, o movimento relatado de cisão entre ela e o outro como presente nas instituições e impossibilitando o diálogo, é desconstruído, favorecendo o estabelecimento de "pontes" de diálogo entre eu-outro, através das quais o trânsito da afetabilidade e das significações pode ocorrer.

Você vai acabar encontrando alguma coisa que te dê... alguma semelhança entre você e aquela pessoa.

A afetabilidade vai sendo expressa como possibilitada por uma abertura para a esfera intersubjetiva sentida na perspectiva clínica dos espaços de construção de significados em supervisão. Através desta vivência, essa abertura para a afetabilidade pelo outro vai se constituindo como instrumento clínico.

Por meio desta compreensão, a depoente reorienta a questão do cuidado presente nas inter-relações com outros para o diálogo sobre a experiência. Assim, compreende os espaços de diálogo acerca da experiência como espaços em que a afetabilidade tem legitimidade para possibilitar o transito do sensível para o significado. Esta possibilidade de uma ressignificação da afetabilidade é compreendida como emergida da própria experiência clínica. Nesse sentido, esse espaço de acolhimento da afetabilidade para a construção de significados da prática é compreendido como pertinente à possibilitação de interlocuções.

A gente teve que ter no decorrer do trabalho uma relação afetiva muito forte para dar conta... para dar conta desse estágio (...) Por que a FEBEM me tocava de tal forma que 
só as pessoas que foram tocadas tanto quanto eu que iriam me entender.

Então quando eu fui assaltada, fazia três meses que eu fazia FEBEM. Eu tinha acabado de contar para os meus pais (...) Que eu contei para os seus pais depois que eu comecei a fazer... Tinha que saber se eu ia gostar (...) então eu vou descobrir primeiro se eu vou gostar. E gostei, deu um tempo eu contei para eles, deu duas semanas eu fui assaltada. (...) aí foi a hora que meu pai falou: “Tá vendo? Não quer matar esses dois?" Falei: "Quero. Esses dois eu quero matar". E... queria matar mesmo, eu não voltei na FEBEM durante um mês. Mas aí eu sabia, vinha para ter supervisão. Por que era o único espaço onde eu me sentia acolhida, à vontade e compreendida. (...) É... é doído, assim, por que você não... você vai se achar incompreendido por um monte de outras pessoas... Então: puxa, como é que você vai explicar para alguém que você atende no pátio? Se todo mundo atende na sala... Como é que você vai explicar (...) que dá para um atendimento acontecer de um jeito superlegal! Como que você vai explicar? Não dá, tem que experimentar.

No âmbito da compreensão da fala como instrumento possibilitador do trânsito de sentidos implicado na elaboração da experiência, a questão da articulação teórica emerge no próprio depoimento como um novo movimento de ressigfinicação. Num primeiro momento a 
depoente se remetia ao espaço de diálogo sobre sua experiência clínica como um espaço para “ouvir”. Num segundo momento, como um espaço para relatar sua experiência para, através do outro construir significações para as formas através das quais era afetada pela experiência clínica. No decorrer do relato sobre seu percurso, as articulações de significado e o trânsito por sentidos possíveis, nos quais se permeia a ressignificação da fala, nas múltiplas esferas - no relatar, no compreender, no refletir, etc. - em que ela se faz presente, possibilitam e favorecem novos espaços de articulação teórico-prática. Compreender a teoria como instrumento de trânsito na reflexão possibilita abranger novas formas de interlocução, circunscrevendo e referenciando a prática a partir de uma apropriação teórica pela experiência.

Mas desde antes, eu lembro quando eu fiz institucional. Foi a minha primeira leitura que eu tentei fazer do nosso trabalho. E aí me confortou absurdamente por que dá para você... encaixar algumas das coisas. Então foi algum jeito de alguém ler aquilo que eu fazia. Mas antes eu precisei descrever muito bem: “Ó, eu chego no pátio, cumprimento todo mundo, não sei quê, não sei quê..." E aí depois ler assim: "Essa parte talvez se encaixe com tal conceito, essa talvez com tal, essa com tal, essa com tal", e aí foi dando uma... todo um contorno para o nosso atendimento, para o nosso fazer (...) Mas precisa de umas construções e umas desconstruções... a todo momento. Tanto teóricas quanto práticas e como pessoais. Então sei lá... A gente escreveu, escreveu falando... tentando encaixar o conceito, mas antes do conceito a gente teve que falar da nossa 
experiência... Por que não existe outro caminho. Pelo menos para isso que a gente faz não existe outro caminho. Todos os trabalhos que a gente tentou fazer aí (...) da graduação (...) tem que explicar o que é que a gente faz, como é que eu me porto, para daí virar e falar olha "Nesse trabalho, com essa disciplina, eu posso falar disso, disso, disso" (...) Daí, mesmo você estudando, dentro de uma teoria mais ampla... você acaba construindo uma teoria sua tipo: "Você atendendo"... Por que autor, é você que lê, você que faz os recortes.

A partir da ressignificação dos espaços de articulação teórica apontando para o trânsito na reflexão, e ampliando as possibilidades de articulação teórico-prática como referenciadoras de uma apropriação teórica pela experiência, torna-se possível situar novamente tanto a esfera teórica em que desenvolve sua prática quanto seu próprio espaço de articulação teórica. Assim, a depoente expressa uma compreensão própria dos conceitos teóricos na perspectiva dos quais desenvolve sua prática, circunscrevendo a Atenção Psicológica a partir da abertura para a afetabilidade ao outro e a outros no trânsito clínico, que possibilitará a constituição de espaços intersubjetivos no encontro com o outro, pertinentes à construção e desconstrução de significados e ao resgate de sentido.

Então, o plantão soa muito para mim, e atenção, soa para mim como muito uma coisa de atitude: você está lá dando margem para que um atendimento aconteça... isso que a gente proporciona é dar margem para que a pessoa 
chegue até você independente de ela pedir para ser olhada ou não. Atenção é assim a partir do momento que você está lá com esse olhar, com esse objetivo, com essa intenção, você já está em atenção...

Acho que é uma postura mesmo, essa postura de abertura: eu vou receber bem, sem julgar, acho que é o primordial... A gente aprende a não julgar... Então por mais que eu tenha meus valores, eu vou pô-los em suspenso e vou ter que escutar os valores do outro, para tentar entender... Afinal eu sou uma pessoa a serviço daquela pessoa. Eu estou na disponibilidade total.

Acerca da questão da disponibilidade como atitude de abertura ao outro, o segundo depoente afirma

eu acho que a Atenção Psicológica estava bem naquela questão de estar disponível, está lá, e eu acho que a questão que me pegava através da Atenção Psicológica é que tinha uma demanda para gente está lá... Então não era uma atenção gratuita, não era uma atenção forçada que se dava assim...

Compreender a teoria como instrumento de trânsito pelas significações possíveis do percebido, no movimento de construção de sentido, e ressignificar a própria perspectiva para a ação clínica, resgatando a legitimidade da afetabilidade e do sensível, vai possibilitando à depoente ampliar as formas de interlocução que se constituem nesta prática. A compreensão da abertura para a afetabilidade como subjacente à ação clínica e ao trânsito de sentido permite 
ampliar a compreensão acerca das inter-relações possíveis entre sujeito e contexto.

Dessa forma, por um lado, as afetações sentidas no contexto, mais evidentes nas instituições, podem apresentar-se como instrumentos para a compreensão dos que dele participam, e da relação que estabelecem com o próprio espaço clínico oferecido. Por outro lado, estas compreensões tornam possível a abertura de novos dimensionamentos e dizeres tanto no contexto institucional quanto no contexto clínico. Assim, a depoente relata uma vivência na instituição como também ampliando suas formas de olhar, pela própria afetabilidade que ela provoca, resgatada como subjacente à perspectiva de uma inter-relação entre clínica e abertura ao percebido para elaboração de sentido.

Com escolar é mais fácil de explicar. Se você recebe uma criança com... para fazer psicodiagnóstico. Então você fala assim para ela: “Olha, eu quero...você recebe cinco vezes aqui na minha salinha, a gente faz tais, tais atividades e depois eu passo um relatório”. É uma coisa. Você tem uma visão da criança. Se você é... faz ir até a casa da criança, vê a criança na escola, se vê a criança em diferentes lugares ocupando diferentes posições... Você vai ter uma idéia total da criança.

Você está lá na FEBEM. Se você recebe um menino aqui... Primeiro (...) ele vai usar uns discursinho todo construído e estereotipado(...) Vai falar: “Ah, já sei, a hora que eu sair daqui eu vou mudar de vida, eu vou... começar a trabalhar, comprar minha casa, casar, arrumar uma namorada, casar ter filhos..." Você vai sair super feliz: 
“Que bom!”.(...) Você se deu mal nisso, (...) está criando uma expectativa que é falsa de uma coisa que é falsa... Que vai ficar sem conhecer a pessoa... a pessoa dele, assim porque ele acha que você vai avaliar. Você não vai avaliar, só que você não vai ter nem chance de dizer isso para ele. Então às vezes ele tem (...) outras coisas que ele quer te dizer, que ele não vai te dizer nem se dar a conhecer por ele. $O$ atendimento não acontece... Fica um trabalho meio... burocrático (...) é uma coisa meio avaliativa: "Ah, ele veio aqui e me disse que, quando ele sair, vai arrumar um emprego. Então, pronto." Burocrático. Eu fico sem saber que sentido teve o crime para ele, que sentido tem essa saída, que sentido teve essa permanência para ele.

Se você vai para instituição... Se você está lá, você vai ouvir que esse discurso... O quê que acontece se eu for lá: eu indo lá, primeiro que eu vou ter uma noção da instituição, que é essencial (...) Eu preciso ter uma noção da instituição, eu preciso ter uma noção desses discursos todos que permeiam essa instituição. Então: como é o comportamento deles lá, como é o que eles têm como regras, o que eles têm que obedecer, o que eles não têm que... Qual é a postura dos funcionários, como é essa dinâmica dessa casa. Então, eu indo lá, eu vou conhecer 
isso, e aí, a partir disso, conhecer o menino.

A questão do contexto institucional como propiciadora da reconfiguração de significados também se mostra no segundo depoimento, em que o depoente ressalta as possibilidades abertas, neste contexto, de ampliação de sua compreensão.

Depois isso foi se constituindo numa outra compreensão... Do contexto institucional, do contexto... Tanto das individualidades, quanto do coletivo que ali estava presente... E, através dessa compreensão, eu fui começando a depurar que essas coisas não eram pessoais e que eu podia adquirir um conhecimento, a partir dessa compreensão, um conhecimento institucional, um conhecimento que envolvia as pessoas que estavam ali $e$ que me habilitavam a estar ali...

Por meio desta ampliação de sua perspectiva, abrangendo novos entrecruzamentos e intertrocas possíveis, a depoente relata uma fluidificação do trânsito por diferentes interfaces do contexto clínico, nas esferas da afetação, do relato da vivência, do trânsito pelos múltiplos apontamentos possibilitados na experiência, da interlocução com outras compreensões sentidas, entre outras. Assim, clarifica-se um movimento de elaboração de sentido, pertinente tanto ao movimento de aprendizagem quanto à prática clínica. A interlocução entre as possibilidades de significação e tecitura do sentido e o resgate da legitimidade da afetabilidade e do sensível vai possibilitando à depoente uma apropriação e compreensão da teoria, de forma a constituir um recurso mais articulado à experiência vivencial e passível de reelaborações no movimento de construção e desconstrução de sentido, como instrumento de trânsito pelas significações possíveis do percebido. 
Assim, neste novo momento, as articulações teóricas realizadas pela depoente são compreendidas por ela também como um relato de experiência, expressando o estreitamento das possibilidades de articulação entre teoria e prática. O diálogo acerca da experiência já aparece tendo como destaque a própria fala como articulação de seu saber e sua experiência, e não mais a fala de outros. Ao mesmo tempo, a possibilidade de articular o próprio conhecimento confere outra dimensão para o questionamento: o interrogar o encontro e o que dele de constrói passa a ser compreendido como um instrumento para a constante articulação. Assim, conforme compreensões se fazem possíveis, a depoente formula "mais perguntas”.

Então, eu vim da FEBEM e a partir do momento que eu fui falando da minha experiência, através dos trabalhos que era feitos em faculdade, eu fui entendendo de outra forma... Depois (...) você vai ficando com mais perguntas...

A apropriação da tecitura de compreensões, através da articulação teórico-experiencial, vai se constituindo como uma ampliação das esferas de diálogo, abrangendo diferentes modos da fala. Desse modo, favorece um estreitamento entre a depoente e seus interlocutores, horizontalizando esta interlocução e situando-a mais proximamente ao contexto dialógico. Assim, a depoente expressa outro momento de sua fala, no qual a legitimidade do dizer já foi construída e que a busca é por uma reflexão constante, cuja necessidade foi apontada pela compreensão do espaço clínico e de atenção como um espaço de desalojamento.

Então, eu procuro muitos interlocutores E vou muito atrás do Renato e da Letícia por que eles não são a Helena Procuro contar muito para outras pessoas, que não fazem o que eu faço, que não tem a mesma linguagem... Para poder me questionar. Para eu ir desconstruindo e 
reconstruindo... Para eu ir entendendo. Eu vou tentando fazer ressoar para mim, da mesma maneira que vou fazendo ressoar para o menino... para ele se entender. Eu tenho que me ouvir falando, tenho que encontrar o que eu digo, para poder construir... Mais ou menos o que é aquilo que eu faço. Ou então eu escrevo: eu escrevo muito assim, eu acho que eu sou a pessoa que mais faz diário de bordo do mundo... Que eu escrevo muito, muito, muito... Eu escrevo, eu relato todos os atendimentos, aí depois eu penso neles um por um... É todo um trabalho bem suado... Mas é por que eu preciso conseguir explicar o que eu faço... Essa necessidade surgiu... para conseguir ter interlocução. Eu vejo pelo Maurício, que corrige os meus diários, é ele que lê os meus diários. E ele fala que ele vê diferenças absurdas entre os primeiros diários e os diários de hoje, que hoje eu consigo construir mais teoricamente as coisas... Eu consigo explicar mais do que antes ou consigo pelo menos formular as minhas perguntas.

A partir da apropriação de uma forma de compreensão do encontro intersubjetivo como um vir-a-ser, que se constrói em seu próprio acontecer, a depoente expressa a emergência de uma articulação entre esta compreensão e a própria identidade, se compreendida como a construção de um modo de ser, enquanto profissional da prática clínica. Nesse sentido, a fala é retomada como elemento de articulação dos significados possibilitados pelas compreensões e pelas percepções sentidas no contexto experiencial, abrangendo esta apropriação. 
Então, para você ir compreendendo, você também precisa ir construindo um modo de se ver psicólogo, e aí tem muito a ver com o modo como você percebe o outro e você mesmo... E acho importante também buscar... Coisas que falem desse jeito.

Sendo a fala compreendida como um elemento de articulação da disposição e da compreensão que vão emergindo na experiência do encontro, a reflexão teórica vai se construindo a partir da possibilidade de articulação destas esferas da experiência, conferindo legitimidade à escolha de significações teóricas que se mostrem pertinentes à experiência. Nesse sentido, a depoente expressa que o se reconhecer e o apreender na teoria se faz, para ela, a partir das possibilidades que a significação teórica oferece de nomear o sensível e o percebido no encontro, possibilitando desvelar o sentido do encontro terapêutico.

Eu gosto de aprender, mas eu gosto de saber que eu posso ser eи mesma ali atendendo por que eи sou eи теsma atendendo... Eu não sou uma tábua rasa que de repente alguém se... usa de espelho, eu não sou espelho, só sou espelho segundo determinadas coisas minhas. Vem da sua sensibilidade, que você mesmo coloca na hora e a partir disso você dá nome. De ir descobrindo tanto o que é um atendimento quanto como é que você atende.

A partir disso, a depoente expressa o resgate da legitimidade da própria percepção nos espaços pedagógicos de diálogo, particularmente na supervisão, apontando para a possibilidade de a afetabilidade constituir-se como captora de um saber e de uma linguagem expressa em nível pré-verbal, constituindo uma interface da esfera clínica. Essa linguagem 
refere-se a experiências que dizem da condição humana.

Que nem quando a Helena foi explicar para uns alunos o Plantão... Na hora que eles voltaram para a supervisão, a Helena falou assim: “-Ah, então vamos lá. Vamos conversar agora: o quê vocês diriam para o cliente?” “Ah, não sei." "- Mas o quê você achou dele, o quê ele quis dizer aquela hora?” “-Ah, não sei, não sei...” E aí sai. Aí, você fala, por exemplo: “- Ah, ela estava, sei lá, ela estava tão confusa” “-Por quê que você não falou?” “-Ah, eu vou falar para ela que ela estava confusa?” “-É...”. São umas coisas pequenas que você sabe, que você sente e que você não fala... Essas coisas que você fala... Coisas pequenas... São de experiência do humano...

A questão da dialogicidade para a compreensão e apropriação das percepções apresenta-se no segundo depoimento, em que se relata

Você ter um espaço de acolhimento da sua experiência, para poder entender o que é da situação de plantão e o que é seu te ajuda a poder ir mudando o seu olhar sobre a situação de plantão, sobre esta lá numa instituição...

É a partir destas tecituras que a depoente constrói, ao final do depoimento, uma forma própria de falar da diacriticidade da relação clínica, e ao mesmo tempo falar de uma aprendizagem experiencial e não informativa, de algo da linguagem que se expressa em um nível pré-verbal, mas que durante o trânsito de aprendizagem, vai podendo ser nomeado.

É como se, no atendimento, ao invés de simplesmente 
falar, você vai deixar aquilo entrar para devolver o dele. Imagina uma gosma, a pessoa que vem ser atendida tá uma gosma, ela não consegue entender nada do que tá acontecendo, é uma coisa meio de passagem é meio assim, a pessoa entra, ela entra em você em alguns lugares... Isso ressoa junto com o seu e você separa: meu, dele, meu, dele, meu, dele... Aí você se sente autorizada a dizer para ele o que é dele... Eu fico pensando por exemplo na 16. Eu entrei ali e eles jogaram uns medos que eu não consegui dar conta... Eu respirei, separei, devolvi, respirei, separei, devolvi, mas sobrou. Às vezes você devolve e não é suficiente, aí você procura a supervisão... Vai falar do seu medo, dessa sua impressão desse seu negócio, dessa gosma que agora é sua. Então... Você vai falar $e$ a supervisão vai te ajudar a separar... O que é dele a gente trata na supervisão. O que é seu você vai para sua terapia e trata. E a supervisão vai fazer isso comigo... Do mesmo jeito que eu faço isso para o cliente.

Assim também, no segundo depoimento, o depoente sintetiza sua aprendizagem Você também aprende a fazer um movimento interno, a ter um olhar, que você foi formando nesse processo, $e$ as coisas podem até pegar, mas ficam mais claras, ou ficam claras mais rápido, você tem mais jogo de cintura, uma habilidade clínica mesmo. 


\section{Considerações Possíveis}

Este trabalho constituiu-se no entrelaçamento de muitos percursos: meu próprio percurso, os percursos trilhados na História do conhecimento, da Psicologia e das práticas educativas, particularmente o ensino de Psicologia, o percurso por propostas contextualizadas de desenvolvimento dos saberes e modalidades de prática psicológica, o percurso histórico do laboratório no qual esta pesquisa foi desenvolvida, o percurso dos depoentes em seu processo de formação...

Estes muitos caminhos apontaram constantemente para construções e desconstruções de compreensões possíveis e resgataram um movimento próprio do existir humano, no seu trânsito pela propriedade e pela impropriedade, como considerado por Heidegger (1927:1997).

Este movimento esteve presente no percurso de constituição histórica da metafísica, no qual o método em sua iniciativa de publicizar as compreensões do ser, se mostrou muitas vezes impróprio para a contextualização do relacionar-se, do conhecer e do existir humano, gerando crises das quais decorreram buscas por novas formas de compreensão.

Entre essas crises, emerge a que constituiu a própria Psicologia como ciência, e novamente construções e descontruções acompanham a constituição da Psicologia científica, ora procurando aproximar o discurso psicológico daquilo que é propriamente vivido na experiência e no contexto em que ocorre, ora distanciando-se na direção de uma conceitualização generalizante. Assim também se apresentou o caminho percorrido pelas práticas educativas e, particularmente, pelo ensino de Psicologia.

É nesse sentido que se buscou o resgate da experiência de aprendizagem através das narrativas: buscava-se por este meio compreender o caminho de apropriação de uma prática clínica na construção de modos pertinentes de ser e fazer. 
Neste percurso, novamente o primeiro fenômeno que emerge é a crise, que se apresenta no confronto com a situação institucional e com a ausência, própria da modalidade de Plantão Psicológico, de um fazer pré-definido que possa abrir a possibilidade de imersão na cotidianeidade. Para HEIDEGGER (1927:1997), a cotidianeidade é o modo pelo qual somos regularmente no mundo e nela somos em um modo impróprio de ser, posto que estamos imersos no mundo, perdendo nosso ser mais próprio.

A crise, em seu sentido etimológico, pode ser compreendida como encruzilhada, ou seja, um momento de suspensão no qual o seguir cotidiano perde sua direção, e assim "quebra as concessões e acordos feitos pelo ser-aí para fugir da angústia” (PROCÓPIO, 2000). Desvelando a angústia, a crise possibilita ao ser-aí encontrar-se consigo mesmo, resgatando sua propriedade.

A vivência de crise relatada nos depoimentos possibilitou a desconstrução de uma fala na impropriedade tal como a teoria vinha sendo vivenciada, posto que estava desarticulada do exercício pessoal da experiência.Assim, a experiência clínica é vivida como um relançar-se na angústia, compreendida na acepção Heideggeriana.

Para Heidegger, a angústia é a condição ontológica do ser-aí, que lhe retira "a possibilidade de compreender-se enquanto absorvido pelo mundo (...) O mundo não deixa de existir, mas perde seu contorno, sua nitidez...” (PROCÓPIO, 2000, p. 43). Na angústia, o seraí se coloca frente a si-mesmo e a seu poder-ser, constituindo-se em um estado privilegiado de abertura para o ser.

O relançar-se na angústia expresso na crise relatada nos depoimentos faz-se em um contexto no qual os espaços pedagógicos de supervisão, de discussão, entre outros, são percebidos como possuindo uma perspectiva de apropriação das compreensões que emanam da relação ali estabelecida. Assim, emergem como lugar privilegiado para possibilitar a 
construção de sentido. Para Heidegger (1927:1997), o sentido se configura como a direção para a qual o ser-aí aponta. Em sua abertura, o ser-aí abre-se coloca-se sempre em uma determinada perspectina, apontando para uma determinada direção. É neste sentido que o seraí constrói seu projeto de ser si-mesmo. No sentido etimológico, projeto significa lançar, sendo assim, o ser-aí se lança para um sentido. Tendo a morte como possibilidade última, que confere ao ser-aí a finitude, o ser-aí se historiciza, compreendendo-se como uma existência no tempo. O sentido para o qual o ser-aí se lança é constantemente resgatado no confronto com a angústia, na articulação entre o humor e a comreensibilidade, possibilitada pela fala.

Essa construção realizada através da fala, vai tornando os espaços pedagógicos lugares de referência por sua perspectiva dialógica. Em seu sentido etimológico, dialogia compõe-se de die, que significa dois, e logos, que significa dizer. Refere-se, portanto, ao falar e ouvir com-partilhado, em que se abre a possibilidade de uma tecitura de significados. Para HEIDEGGER (1927: 1997), a fala é o elemento de articulação dos significados proporcionados pela disposição (estado de ânimo) e pela compreensão (o compreender original que possibilita ao ser-aí projetar possibilidades). Esta articulação se faz na abertura original ao ser, designada por HEIDEGGER (1973) como clareira. Nesse espaço no qual as falas podem transitar, é possível também a tecitura de novas interpretações, como possibilidades de orientar a compreensão. Nas palavras de HEIDEGGER (1927: 1997)

"O projetar do compreender tem a possibilidade peculiar de desenvolver-se. Ao desenvolvimento do compreender designamos interpretação. Nela o compreender se apropria, compreendendo o compreendido... A interpretação não toma conhecimento do compreendido senão o desenvolvimento das possibilidades pelo 
compreender.” (HEIDEGGER, 1927: 1984 p. 166)

Assim, ao construir um campo de dialogia no qual se pergunta pelo ser, o próprio espaço pedagógico encontra sua interface com o campo clínico, possibilitando uma aprendizagem experiencial, no si-mesmo, da articulação entre disposição e compreensibilidade favorecida pela fala. Isto porque ele também se constitui como abertura, como um espaço de questionamento sobre a experiência no qual as articulações possíveis acerca da experiência daquele que atende não se encontram pré-definidas. Nesse sentido, há também no espaço pedagógico a abertura para um não saber, a partir do qual as interpretações e articulações podem ser tecidas, o que se evidencia considerando-se que o contexto no qual o espaço pedagógico se insere é também um contexto de pesquisa.

Pode-se compreender a clínica como um espaço diacrítico, que em seu sentido etimológico constitui-se de die, que significa dois, e crise, que significa encruzilhada, podendo se referir, no contexto clínico, ao entrecruzamento de percepções e afetações da esfera intersubjetiva. Pode-se aprofundar esta questão a partir de MERLEAU-PONTY (1990). Segundo ele "a percepção influi nas relações entre mim, enquanto tenho um corpo, e o mundo” (p. 291) e “a percepção do outro não é somente a operação dos estímulos exteriores, ela depende também largamente da maneira pela qual estabelecemos nossas relações com os outros” (p. 295). Nesse sentido, as percepções e afetações se fazem em trânsito na relação euoutro, considerando-se, também, os modos pré-verbais de compreensão. Dessa forma, elas se fazem na experiência, e implicam uma abrangência de si mesmo como participante desta relação.

Desse modo, a aprendizagem vai se construindo no desvelar, através da experiência, de uma pertinência, tornando-se própria e ganhando significado na medida em que considera a multiplicidade de esferas compreendidas na construção de compreensões e interpretações. É 
no encontro consigo que a compreensão do encontro com o outro na prática clínica vai se tecendo, constituindo-se em uma experiência auto-apropriada do fazer clínico.

Nessa direção, pode-se compreender o aspecto pedagógico e o aspecto terapêutico como duas interfaces do movimento de cuidar de ser sobre o qual o campo clínico se debruça no sentido de possibilitar e favorecer o projeto de si-mesmo.

Assim, o movimento de aprendizagem apresentado pelos depoentes aponta para uma interface entre o aspecto clínico e o pedagógico desta prática e para uma dialogia que se apresenta não apenas no encontro com outros - o cliente, o supervisor, os pares - mas que também se mostra na articulação entre teoria e prática.

Nesse sentido, a horizontalidade destas esferas permite uma constante rearticulação do próprio percurso de formação e das compreensões e interpretações construídas ao longo deste percurso, favorecendo a apropriação de um saber. 


\section{Apêndice}

\section{Depoimento 2}

O caminho que fui percorrendo para compreender foi a partir de uma prática... que eram os estágios que a gente fazia na graduação que tinham os atendimentos. Mas eu acho que, falando mais especificamente dos projetos, eu entrei meio que de gaiato... a partir de pessoas que eu conhecia que me convidaram para trabalhar em instituições e eu fui, sem muito saber o que aconteceria... Fui participando e fazendo visitas. Essas coisas já estavam rolando antes de mim e... quando eu entrei assim... eu acho que a Atenção Psicológica estava bem naquela questão de estar disponível, está lá, e eu acho que a questão que me pegava através da Atenção Psicológica é que tinha uma demanda para gente está lá... Então não era uma atenção gratuita, não era uma atenção forçada que se dava assim... Por que...

Era uma coisa que vinha de um pedido da própria instituição e... Às vezes, muitas vezes, era nisso que eu me arvorava para estar lá, que as coisas ficavam mais complicadas é... de que tinha uma demanda, ali, de que aquilo tinha existido, tal, de que não era, é... Uma coisa que eu quis é... Não estou conseguindo explicar, que... Bom, tinha um sentido de eu estar ali. A partir daí, eu acho que... Eu fui passando por um longo processo de como entender essa atenção psicológica que tinha a ver ao mesmo tempo em que... com coisas internas e com coisas externas... Acho que uma era entender a proposta é... desse projeto do qual eu participei. A outra era eu me dar conta de certos movimentos que eu realizava nessa compreensão. Então, num primeiro momento era muito importante para mim atender no sentido de estar fazendo um atendimento com uma pessoa singularmente ali, uma coisa que tinha a ver com a minha experiência na graduação. Quando isso não começou a ocorrer eu comecei a entrar numa crise e... também assim, de apreender qual que era a proposta do 
projeto, entendeu, de que esses atendimentos poderiam ocorrer de outras formas De que... Uma série de coisas de que a nossa entrada ali já era uma, uma forma de indicar um mal estar, de que a gente estava... Estava sendo institucional a nossa entrada, de que isso já era um atendimento, de que o plantão se configurava como disponibilidade, só que isso também não era fácil, a questão dos movimentos internos... Que uma coisa que essa disponibilidade de estar lá... Era uma coisa que fisicamente era cansativa, de ficar disponível, de ficar atento, e cansava muito, e ao mesmo tempo tinha que lidar com essas questões que me surgiam de impotência, de onipotência, no sentido de buscar o que é que eu estou fazendo ali, por que se eu não conseguia resolver alguma coisa, eu caía na impotência... Mas o que era resolver essa coisa? Quando eu me debruçava para olhar isso, eu percebia que eu estava buscando uma resolução onipotente para coisa... E... Então teve esse diálogo, assim... A apreensão do que era esse projeto, do que ele se propunha enquanto prática clínica e um diálogo com como essas coisas ecoavam em alguns movimentos internos. Eu vinha de uma prática da graduação na qual era mais fácil entender o que eu estava fazendo ali... a partir dessa prática que eu já tinha antes? É, eu acho que sim, assim, que era bem mais fácil por que... Aí eu acho que entra essa questão... Eu acho que era bem mais fácil por que era uma prática voltada para o ensino e essa prática que eu comecei a participar no projeto estava muito mais voltada para aprendizagem e eu acho que nesse sentido... Quando eu falo da prática que eu tinha na graduação enquanto ensino é por que ela já estava toda balizada por onde deveria seguir, então você tinha uma série de... de ganchos, é... na determinada disciplina, no curso... Que você voltava essa experiência para um determinado fim já.... Já pressuposto, então... Você vai atender... Métodos, que era uma disciplina, você tem que fazer um psicodiagnóstico, então já tinha um fim em vista, já tinha um horizonte em vista, é... Depois a outra experiência clínica que a gente teve era... O SAP, e tinha um atendimento, mas também já estava em vista de que 
tinha que ir até o encaminhamento, ou que só ia ter determinados encontros e de que tinha a ver com você apreender as atitudes básicas do Rogers, de você estar sendo balizado por isso... Então, essas práticas... Elas estavam enquadradas num contexto de ensino. Quando eu digo que eu entrei nos projetos e que era uma questão de aprendizagem... Foi que eu não tinha um norte definido de onde eu deveria chegar e as coisas que iam surgindo elas iam sendo apreendidas para mim e iam mudando esse horizonte Se eu tinha uma perspectiva onipotente, aquilo logo foi para o chão... Então acho que nesse sentido... Na graduação era muito mais fácil eu entender o que eu estava fazendo por que tinha... esses artifícios. No projeto, foi uma coisa que não me foi dada, foi uma coisa que eu tive que criar. Coletivamente? Sim, coletivamente, não foi uma coisa de criação solitária, mas é... as pessoas também estavam buscando essa sua própria construção. Quando eu falo que as coisas iam aparecendo, esse negócio de criar...

Que coisas eram essas que iam aparecendo? Coisas aparecendo no sentido de... Acho que, quando apareciam coisas que eu tinha, acho que invariavelmente você vai com uma expectativa, acho que quando apareciam coisas que se enquadravam nessa expectativa, elas... Tudo bem. Agora, quando apareciam coisas que não se encaixavam, eu acho que é aí que essa aprendizagem começava. É... Por exemplo, uma coisa que aparecia logo de início é que a gente tinha uma demanda para atender... Para estar lá fazendo essa atenção psicológica, $e$ quando a gente estava lá não apareciam pessoas para atender, não apareciam pessoas buscando esse atendimento... Isso me quebrava as pernas, isso era uma coisa que esse não aparecer das pessoas revelava uma série de coisas que a princípio eu levei para uma compreensão particular, de que... Eu não estava sendo bom profissional, mesmo eu estando na graduação... De que eu não estava conseguindo me aproximar...

Depois isso foi se constituindo numa outra compreensão... Do contexto institucional, 
do contexto... Tanto das individualidades, quanto do coletivo que ali estava presente... E, através dessa compreensão, eu fui começando a depurar que essas coisas não eram pessoais e que eu podia adquirir um conhecimento, a partir dessa compreensão, um conhecimento institucional, um conhecimento que envolvia as pessoas que estavam ali e que me habilitavam a estar ali de uma outra forma muito mais tranqüila, sem levar para o particular nesse sentido... Como que essa compreensão foi acontecendo na minha experiência? Essa compreensão basicamente foi acontecendo na supervisão. Eu acho que, que é aí que as coisas, que é aí que essa compreensão surgia, por que no Plantão, que nem eu disse no início, as coisas iam para um lado que eu pegava para o pessoal mesmo, que eu não tinha... Não tinha outros parâmetros, não conseguia achar outros parâmetros aonde me apoiar para estar buscando uma compreensão... Daí eu pegava para o pessoal... Daí eu trazia essas questões, do que tinha acontecido, de como eu tinha interpretado, coisas que tinham acontecido, ali para supervisão... A partir daí essas coisas... elas eram, elas eram olhadas para pensar assim: "olha, isso não é pessoal, isso pode ser entendido de uma outra forma, por que é uma instituição assim, assim, assado, ou por que... etc, etc"... Ou por que uma série de coisas que iam me esclarecendo, ou por que outras pessoas já tinham entrado em contato com essa pessoa a já tinham tido essa experiência... Então não era assim, que a pessoa foi mal educada comigo, ou foi grossa comigo, era o modo de a pessoa utilizar-se do serviço... Ela chegava dessa forma... Agora, essas outras coisas já são mais pessoais, então meio que discriminava assim... O que é meu e o que era do plantão? O que é meu e o que era uma coisa que aparecia clinicamente assim... E que não tinha muito por onde fugir, porque o modo de apreensão clínico... Ele passa pelo modo subjetivo... Mas, até aí, não precisa ser compreendido só como pessoal, que daí eu acho que já sai da esfera clínica, da esfera profissional e... Impossibilita o trabalho, mesmo, porque você não consegue ficar. 
Como a supervisão foi me ajudando a perceber isso? Ou como foi eu na supervisão percebendo isso? Eu não sei ao certo como dizer assim... Eu posso dizer alguns exemplos, mas eu acho que... Era uma coisa de... Acho que era muito... Bom, você poder estar sendo compreendido por outras pessoas... E você estar sendo cuidado por outras pessoas e que aquilo não era uma viagem só sua, aquilo cabia dentro. Então você podia... Trazer por inteiro as coisas que você estava anunciando, porque quando você estava no plantão, quando você estava nesse trajeto, na pressão psicológica, da forma como a gente estava, você não estava lá por inteiro... A gente estava atento, a gente estava numa prontidão que se dava a todo tempo, que não era uma questão de “Ah, eu só vou estar assim quando o fulano vir...” Tinha umas comunicações que, que... Aconteceu o tempo inteiro, mesmo a pessoa vindo diretamente ou verbalmente falar com você. Então o fato de poder me trazer inteiro a partir... Na supervisão, a partir dessa experiência clínica, e isso estar sendo legitimado como... Relevante numa supervisão... E eu poder estar sendo cuidado. Então não só um olhar visando um cliente, ou o caso, mas como essas coisas estavam me afetando... Acho que esse foi o modo como as coisas foram mudando... Acho que teve o cuidado das pessoas em justamente não me atropelar... E de certa forma também estarem dizendo que também já passaram por isso... Ou dizendo que não passaram por isso, que também era valioso... Trocando essas coisas assim eu conseguia... Estar trabalhando comigo essas experiências... Então eu acho que é um trabalho em conjunto, mas também um trabalho solitário... Porque se você também não está aberto numa supervisão para estar reformulando suas concepções, reformulando... Aquilo que você tem de pressupostos a partir dessa prática, não adianta aquelas pessoas estarem atentas ali... Então é um trabalho coletivo, as pessoas apontavam, as pessoas cuidavam, mas eu também estava aberto a estar recebendo essa comunicação, esse cuidado disposto a um amadurecimento profissional... É que o espaço da supervisão era um espaço... Um espaço 
coletivo... de cuidar da minha... Da minha prática, do plantão... De cuidar do cliente também... Mas era um espaço solitário porque... Como eu vou dizer? Porque diversas coisas eram comunicadas ali que... Modificou, que tem essa... Que tinham essa potencialidade de... De me transformar, de eu rever a minha prática... Se eu... Mas para eu rever isso era uma coisa individual, uma coisa no silêncio... O quê das coisas comunicadas que possibilitavam rever minha prática? Por exemplo... A gente fazia... Teve uma época que a gente fazia plantão e a gente começou a ficar angustiado porque as pessoas não estavam aparecendo e... E eu tinha... teoricamente, intelectualmente, assim... De que isso tudo bem, de que isso acontecia, de que a instituição realmente era assim... Mas ali, na prática, não era isso que eu vivenciava... Não era isso que acalmava... Eu vivenciava uma angústia muito grande de querer fazer alguma coisa, de querer... Aprender... De querer, estar... De querer sair dali no sentido de fazer alguma coisa... Ter uma função? Queria estar achando um sentido em estar ali buscando esse atendimento...

E essa compreensão intelectual, informativa, de que essas coisas poderiam acontecer, porque o plantão era uma disponibilidade... Elas não me amenizam enquanto profissional... Isso eu trouxe na supervisão e... E a gente trouxe isso, e... Foi muito doloroso, muito enriquecedor, mas muito doloroso porque eu ficava insistindo que a gente poderia fazer, por exemplo, grupos... Uma dinâmica de grupo, a gente poderia fazer... Reuniões com o pessoal com determinados temas... Eu defendia arduamente isso e... os supervisores e algumas outras pessoas... Ficavam apontando para a minha dificuldade de estar ali, na especificidade, naquilo que o projeto se propunha... E mais do que isso... ...Apontavam para a minha angústia de eu não estar bem... Nesse mal estar... De eu não conseguir ficar ali, de eu não conseguir dar conta de não aprender, de eu não conseguir dar conta de não ter cliente, de eu querer buscar o cliente, de eu querer criar uma demanda por grupo ou por uma coisa tal que... ...Que 
não era uma demanda... Pertinente... No sentido de que as pessoas que pediam também estavam muito sem saber o que pedir... Daí, assim, no primeiro momento, as pessoas que apontavam para todo esse mal estar e essa angústia minha... E eu não... E eu chegava a achar que era sacanagem, assim feito... Tudo bem, mas é isso mesmo que estou querendo resolver, por isso que eu quero fazer esse grupo e as pessoas falam assim "Antes de... a gente compreende essa vontade de fazer, mas antes de fazer vamos olhar para essa angústia que é anterior a... A gente pensar numa proposta do que... de que atividade a gente deve fazer..." $O$ quê que está acontecendo ali, o quê que está trazendo ali... E eu tinha essa dificuldade de falar assim: “Não, como assim?” “Não... É isso, entendeu?” E...E daí, assim... E isso foi um coletivo... E daí internamente essa questão do solitário, é que o negócio é assim, enquanto rolava essa questão coletiva, eu internamente pensando comigo, eu falava assim: "Não, mas é... realmente - é...- tem uma coisa aí que é anterior, - entendeu? - tem um mal estar que é anterior..." E ia pensando, assim, de que: “Não, realmente é legítimo isso... De a gente pensar anterior, anteriormente à execução, assim, do que, é... do que a gente está fazendo... E......e tal, assim... e - é difícil falar assim... Daí eu acho que... que eu estou...

Eu acho que tem essa comunicação, e eu falo individual... As coisas eram apontadas em grupo, e isso, por antecipado era contado em grupo, é... eu me refutava às vezes disputar isso porque muitas vezes um grupo poderia também estar equivocado... - entendeu? ...naquilo que eles estavam querendo me apontar, então eu fica assim: “Onde...” - né? ...assim... - “Onde seguir?” ..assim... E daí, é... Eu tinha que de certa forma me lançar porque acho que aquele grupo podia cuidar daquilo, entendeu? Confiar de que tinha uma equipe, de que não estava solitário, e... E trazer isso para, é... trazer essa solidão, trazer essa dificuldade trazer, é... essa dor de estar aprendendo profissionalmente, de estar crescendo profissionalmente... é... ...de estar aprendendo esse modo clínico, essa modalidade clínica... 
...como relevantes para tarem sendo discutidos em supervisão antes... ...de estar só trazendo a uns fazer tal e tal tarefa ou vamos fazer tal e tal coisa... O grupo apontava... O supervisor ou o grupo apontavam para esse cuidado.... É... E num princípio eu me refutei... No outro princípio eu aceitei e trouxe essas questões pessoais e profissionais como relevantes... ...mas... se... na minha... na solidão ali que eu vivenciava porque é... ...se eu mantivesse uma posição de resultado, eu entraria e as coisas poderiam ser seguidas... O que aconteceu para que eu mudasse de posição?

Eu acho que... O que aconteceu é justamente pensar... De que se fosse um trabalho sem uma equipe seria insuportável... E... Então eu precisava ter uma confiança naquela equipe... E para ter confiança naquela equipe eu precisava estar me lançando, estar aprendendo... Eu não entendi, assim... Eu não sei o que aconteceu, é uma coisa - eu acho que aí é... é difícil assim... Eu acho que na hora te cai uma luz do tipo "Ah! Então eu vou falar que na verdade eu estou com medo... Então eu vou falar que me sinto uma merda...” E eu acho que isso é uma coisa que te passa na hora, assim, do tipo: “Ah, se eu não falar isso, eu não quero mais fazer essas coisas.." Se eu não trouxer isso, eu acho que não dá para ficar mais... Porque... É uma coisa que é insuportável... Acho que é uma coisa do insuportável, mesmo...

Você ter um espaço de acolhimento da sua experiência, para poder entender o que é da situação de plantão e o que é seu te ajuda a poder ir mudando o seu olhar sobre a situação de plantão, sobre esta lá numa instituição... E esse espaço... E é isso que é... ..Difícil... Porque esse espaço por si só... de acolhimento... Ele é necessário, mas não é suficiente... Porque você precisa criar esse espaço também dentro de você para colher essas coisas... É isso o que eu quero dizer da questão do coletivo e da solidão porque... Você precisa ter esse espaço, você precisa ter essas pessoas e você precisa ter toda uma movimentação nesse sentido... E se você 
não cria um espaço interno... De acolher essas coisas como relevantes para você... Não cria isso, ou não traz isso... Não adianta. Eu acho que funciona é nessa, é nessa coisa de um pouco de diacrítica... De que é preciso ter um espaço fora porque senão também você traz coisas que o grupo reputa... Mas, aо mesmo tempo... Você precisa ter um espaço interno porque senão o grupo traz coisas e você reputa... Precisa ter esse diálogo...

Como é que é que há esse espaço? Acho que de início... Assim... O grupo criou esse espaço... E o grupo mostrou que era pertinente... É... A supervisão mostrou que era pertinente criar esse espaço de acolhimento. Daí que eu fui percebendo em mim que esse espaço tinha que ser cultivado, tinha que ser criado e que a partir de então eu poderia ter esse espaço dentro de mim e poderia até levá-lo para uma prática clínica... Nos moldes clássicos... Esse espaço constante de questionamento do sentido da minha prática, do meu sentido enquanto profissional, do meu sentido na sociedade... Esses vários âmbitos de um cuidado comigo, de um acolhimento comigo para eu poder cuidar de um cliente.

A experiência de ser acolhido numa supervisão me possibilita ter um acolhimento interno? É isso. E eu estava falando de o grupo ter um acolhimento que possibilita eu "me lançar"... Como é isso, de "me lançar"? Bom... Eu falei em "busca de um sentido" e que em outras práticas que eu tinha, o sentido já estava dado, e de a partir daí eu ia buscando os sentidos onde quer que eu estivesse... Acho que as coisas que a gente ensina, esses estágios... Não é nem que "já tinha um sentido que já estava dado”, já tinha um direcionamento que já apontava para um sentido, mas... O sentido sempre é você que cria, então muitas vezes ... Por mais que apontassem para um determinado sentido - eu estou fazendo um psicodiagnóstico... Quando eu passava por aquilo, aquilo não fazia o menor sentido, da forma como era feita, não psicodiagnóstico da forma mais conhecida, mas da forma como era feita... Ou então achava uma maravilha, quer dizer... Eu poderia criar vários sentidos... Agora, essa questão... 
Pegando mais essa questão do “se lançar”... É que eu me inseri como plantonista, estagiário... De um projeto de um laboratório que estava propondo determinada prática clínica... E a forma como eu iria ser ensinado ou aprender, essa forma clínica... Era diferente dessa forma de ensino, quer dizer: Eu ia lá desde que quebrar a cara! Era doloroso quebrar a cara porque...

Em outros lugares eu quebrava eu quebrava a cara sim... ...só que... Em outros lugares eu quebrava a cara sim, mas ali era diferente...Acho que eu acho que eu quebrava a cara de me frustar assim... É... Não tem nem como dar exemplo porque eu não sei do que eu vou falar, assim... Acho tem um "quebrar a cara" num sentido... Vou fazer uma matéria que tenha atendimento, entendeu? De repente eu percebo que não era bem esse tipo de atendimento... Que não era bem esse tipo de experiência que eu queria ter... Por exemplo: primeiro eu queria atender com a Vanessa, porque tinha gostado da aula dela, de repente eu quebrei a cara porque, da forma como as coisas aconteciam... Não era muito bem por aí... Eu teria quebrado a cara por aí... Mas também quebrava a cara no atendimento... Era a parte clínica porque, era me passado uma determinada orientação, uma determinada supervisão, e eu chegava naquela prática clínica, com aquela orientação, com tudo aquilo na cabeça e não rolava, mesmo assim... Então era uma segunda quebrada de cara... Porque eu quebrava a cara, por de certa forma estar me frustrando, ir contra uma disciplina que eu pensava... Achar que ia ser assim e assado e não era... E também quebrava a cara porque... Clinicamente atendendo ali, eu ia com o que era passado e não rolava o que era esperado... E daí eu voltava e falava "Olha, aconteceu isso..." E daí... De certa forma me pediam, me demandavam um jogo de cintura... E eu não tinha esse jogo de cintura...

Um jogo de cintura do tipo assim... O cliente tem uma problemática na relação com o pai, então é bom ver isso... Então na próxima vez você propõe uma atividade tal... Ou então da 
próxima vez que ele citar o nome do pai você tenta seguir um caminho tal para ele falar disso - entendeu? E eu chegava na clínica, eu propunha uma coisa, a pessoa não queria fazer, ou então propunha - é... - uma atividade, mas se mantinha só a atividade, não se questionava e... Ou então, assim, o cliente trazia coisas... Que aquela orientação que eu tinha recebido não dava conta, e nesse momento eu tinha que ter jogo de cintura... Para poder criar, para poder utilizar aquilo que ele traz e eu não conseguia ter esse jogo de cintura... Eu ficava, assim, mal... E... E... Eu acho que daí eu ia para supervisão, a supervisão não rolou e não sei o que... Daí eu me sentia um pouco atacado no sentido de "Ah, eu você tem que ter um jogo de cintura!"... Mas eu não sabia como ter um jogo de cintura, eu num pu... E, e quando eu trazia que eu não tinha esse jogo de cintura, eu não me sentia acolhido, assim como "Ah, isso acontece...” Mas isso era numa disciplina, entendeu? Eu acho que quebrar a cara - é... - num projeto... ...estava assim... ...foi uma coisa que, que era diferente, porque não é que eu me frustrei porque eu esperava uma determinada coisa que ninguém dava... Aquilo que era dito a respeito do que era um projeto de atenção psicológica eu entendia, não me frustrava. Agora, como era feito, demandava... Uma certa perda dos referenciais para poder estar entendendo, para poder estar atuando clinicamente... Eu acho tão difícil essa pergunta que você fez...

Quando eu cheguei lá, de repente tudo aquilo que eu aprendi... Não é que era uma orientação errada, é que simplesmente não tinha uma orientação a priori e me fazia descontruir as coisas que eu tinha? É, não tinha uma orientação a priori, por exemplo, a Lélia conversa para este lado, o Aurélio conversa para este... Tinha uma coisa do tipo assim: "Ah! Fique atento... A você, se você estiver suspendendo determinados sentimentos e tal... Porque isso pode complicar o atendimento... Agora você não sabe como a pessoa vai surgir... Então já partia do pressuposto clínico de que eu ia quebrar a cara porque eu não tinha parâmetro do que iria ou não acontecer. Iria acontecer o desconhecido. E é... Isso, assim... Eu 
ainda não estou conseguindo... Eu quebrava a cara no sentido de se abrir para uma coisa que não conhecia e daí não poder usar as referências que eu tinha... E que aí, a referência que eu... Acabei tendo foi o grupo de supervisão? No sentido: Eu tenho, eu me lanço para uma coisa que eu não sei o que é, mas tenho um lugar que me acolhe mais ou menos, e aí eu posso me segurar ali? Mais que isso, a referência era que aquilo, por mais dolorido que fosse, fazia sentido para mim, essa era a referência... Como assim fazia sentido para mim? Sentido é alguma coisa que fazia sentido para mim, ali, para mim, mas eu acho que é super impossível eu falar "o que" num sentido que vai muito além do verbal... Eu não conseguiria, assim... É aquelas coisas que geralmente a gente fala que "Ah! Que saco, ocorre!" Mas por que a gente não sai fora? Porque aquilo faz um sentido... Faz um sentido... Enquanto formação profissional, enquanto clínica... Acho que não deu para entender justamente porque eu falei, porque o sentido é indizível. Não vou conseguir falar o que fazia sentido ali. Acho que tinha esse acolhimento do grupo... Mas o grupo já saiu o mais acolhedor possível! Se aquilo não tivesse fazendo sentido para mim... Eu não... Não iria ficar. Eu acho que fazia sentido... Ou então, porque assim... Às vezes eu ia para o plantão... E quebrava a cara, ou perdia as referências... Ficava pesado, aquilo não tinha sentido... Daí era a supervisão, aquilo começava a fazer sentido... Para mim... Aquilo era acolhido por mim... E daí eu falava "Ah, então... Puxa! Consegui achar um sentido!"... Nesse caminho... A partir do grupo, usando o grupo como referência, como espaço e que a gente buscava um sentido, foi isso que me manteve... E aí, de repente chega lá e tal, fica perdido e depois na hora de você rever a experiência... falar da experiência, eu comę̧ava a enxergar algumas coisas? É... Que nem no início da entrevista eu disse, começava a discriminar as coisas e a partir dessa discriminação começava a produzir um conhecimento, que não era um conhecimento informativo, era um conhecimento vivencial... 
Um conhecimento assim: "Agora eu sei, eu sinto, eu vivo que é assim, não é assado." Entendeu? Agora, por exemplo, eu sei que... Agora eu sei, por exemplo, que - esse exemplo não nem é meu, mas eu vou tomar para mim... Os policiais estarem armados ali e ficarem conosco armados... De que a arma era uma, era uma coisa super comum para eles, do tipo como o caderno poderia ser para mim, era um instrumento de trabalho para eles e... E não era uma grande questão para eles - a arma, não o tiro ou a morte. Mas a arma não era uma grande questão, e de repente, quando eu entrei, a arma, aquela ostentação da arma no coldre, ou pegar a arma, levantar a arma, girar a arma... Aquilo era muito agressivo para mim, aquilo pegava numa exibição de poder, aquilo dizia de uma fragilidade minha com relação a que um tiro ali poderia acabar comigo... E de que estava me agredindo, então, se eles estavam fazendo aquilo... E de repente não, de repente... Assim, na supervisão, eu tive o espaço para ver que não, que era o instrumento de trabalho deles, que aquele tipo de atitude que eles tinham não era para me agredir, embora algumas vezes fosse, mas não eram todas as vezes... Então, assim, se eu podia saber que algumas vezes aquilo, aquilo era usado como agressão, então eu poderia instrumentalizar aquilo para quando houvesse essa comunicação, eu utilizar aquilo como uma forma de atender... Outras vezes não, então outras vezes eu não precisaria ficar me preocupando com a presença da arma. Então acho que é isso... A partir dessa coisa de me lançar num lugar, que eu não conhecia e construir um sentido, a partir do momento em que vou discriminando o que é meu, o que é do outro, consigo construir um sentido para levar essas coisas que o outro me traz? É e... Como conduzir essas coisas clinicamente tendo como horizonte essa atenção psicológica. Conduzir clinicamente assim... Buscar uma forma de responder aquilo que você representa, agora... Qual é essa forma? É... Eu não poderia dizer assim: "Ah, é uma forma tal" - no sentido de... "Ah, se o cara apresentar uma arma de forma agressiva, então resposta tal” Não dá, não cabe. 
Acho que é muito mais do que isso, inclusive clinicamente no sentido de... Perceber a complexidade que está acontecendo ali entre as subjetividades, entre essas subjetividades nessa instituição, nessa determinada relação que você estabelece e poder responder a isso, sendo que ficar em silencio é uma resposta, responder é... Falar num determinado tom de voz é uma resposta. Levantar e sair andando é uma outra resposta... Então tem um leque de opções e eu posso ver assim... Que por exemplo, num determinado contexto, qualquer resposta é cabível... Eu não posso sair a priori com um tipo de resposta para aquela situação. Mas quando você fala clinicamente, você está falando de uma determinada forma de responder que não é qualquer uma. Quando falo "procurar uma resposta habilidosa”, o “habilidosa” é uma forma de responder que não é qualquer uma... Cabe qualquer uma, mas dentro do contexto de estar buscando atender esse cliente... Estar buscando... O cuidado com essa pessoa... Uma atenção psicológica para essa pessoa... Então eu acho que... achava que, às vezes, a empatia, com essa atenção psicológica... Já ia se dar, e muitas vezes não era isso que o correu, muitas vezes você tinha que clinicamente... Dar uma resposta... Assim, de levantar e sair, ou não responder ou retrucar... Justamente para aquela pessoa começar a tentar e a se dar conta de como ela era agressiva, por exemplo... E a partir do momento em que ela poderia ter ou não essa percepção, aí sim ela poderia estar me buscando de outra forma para ser atendida. Estou falando de poder devolver para o outro o jeito que ele chega?

É... mas não devolver “ Ipsis literi”... Eu acho que daí, eu acho que aí que é complexo, não dá... Por exemplo, uma pessoa agressiva, que vem assim, eu posso... Devolver para ela de uma forma carinhosa... E de repente ela pode falar : "Puxa, eu estou sendo um grosso!” A pessoa vem agressiva e eu respondo de uma forma muito: “Oi, não sei o que...” Essa pessoa pode se dar conta do quanto ela está sendo agressiva naquele momento. Por um lado, eu posso responder também grosseiramente e a pessoa perceber que: "Nossa, espera aí..." Quer 
dizer... Eu respondo, mas... Aquilo pode cair no vazio também. Aquilo pode não dar... Aquela resposta pode não ser compreendida

Estou falando mais ou menos de através da minha atitude, mostrar o significado que a pessoa me trouxe ou o conteúdo que a pessoa me trouxe? Para ela poder perceber isso... Para ela poder se tocar, muitas vezes, de que... Aquilo, que da forma como ela se apresenta diz muito do que ela está falando verbalmente... E isso eu acho que as, e isso eu acho que é uma coisa que... Que é mais, que é de um olhar profissional, psicológico. Assim, de você atentar para essa forma como essa pessoa se apresenta como também sendo consistente com aquilo que verbalmente ela está trazendo. E você apontar isso, e a pessoa... E isso é um efeito muito grande na pessoa. A partir do momento que eu estou conseguindo discriminar o que é meu,e o que é de lá, você consegue...

Pegar isso que é de lá e vem para você e aí poder mostrar esse significado para o outro começar a perceber nele mesmo? Eu acho que é esse o caminho que eu estou tentando fazer... Acho que é esse o caminho que eu estou tentando fazer. Mas é isso... Eu acho que vai... Mas acho que de repente tem uma... Você tem experiência clínica e de repente você acha que voltou a estaca zero, mas você não volta à estaca zero porque uma coisa que ficava te pegando durante meses, não te pega da mesma forma. Então, vou dar um exemplo, assim, essa questão da agressão que ficava durante meses te pegando... De repente surgiu uma outra questão ali que, vamos dizer assim, seja machismo... Aquilo te pega num $1^{\circ}$ momento mas não fica mais... Você também aprende a fazer um movimento interno, a ter um olhar, que você foi formando nesse processo, e as coisas podem até pegar, mas ficam mais claras, ou ficam claras mais rápido, você tem mais jogo de cintura, uma habilidade clínica mesmo. 


\section{Referências:}

ADORNO, T. W. A dialética do esclarecimento. São Paulo: Objetiva, 1985.

AMATUZZI, M. M. O resgate da fala autêntica - filosofia da psicoterapia e da educação. Campinas, SP: Papirus, 1989.

ANTUNES, M. A. M. A Psicologia no Brasil: leitura histórica sobre sua constituição. São Paulo: Unimarco: EDUC, 2001.

ARENDT, H. Entre o passado e o futuro. São Paulo: Perspectiva, 2001.

ASH, S. E. Psicologia Social. Trad. Dante Moreira Leite e Miriam Moreira Leite São Paulo: Nacional, 1966 2ed.

BASAGliA, F. Psiquiatria Alternativa : Contra O Pessimismo Da Razão, O Otimismo Da Paratica: Conferencias No Brasil São Paulo : Brasil Debates, 1982 3ed

BENJAMIN, W. “Experiência e pobreza” São Paulo: Brasiliense, 1985 Em: Obras escolhidas, v.1

. “O narrador: considerações sobre a obra de Nikolai Leskov”São Paulo:

Brasiliense, , 1985 In: Obras escolhidas, v.1

. “Magia e técnica, arte e política” São Paulo: Brasiliense, 1985 In: Obras

escolhidas, v.1

BLEGER, J. Temas em psicologia: entrevista e grupos. São Paulo: Martins Fontes, 1998.

BRAGA, T. B. M., NUNES, A. P., MORATO, H.T.P. e cols. Espelho Mágico: Transformações num Serviço de Plantão Psicológico na Polícia Militar do Estado de São Paulo Relatório Técnico Científico São Paulo, IPUSP, 2002

BRAGA, T. B. M., NUNES, A. P., MORATO, H.T.P. e cols. .Espelho Mágico: Transformações num Serviço de Plantão Psicológico na Polícia Militar do Estado de São 
Paulo. Em: 55 $5^{a}$ Reunião Anual da SBPC, Recife: UFPE, 2003. Anais da 55ª Reunião Anual da SBPC. , Recife: UFPE, 2003.

CABRAL, A. C. M. “A Psicologia no Brasil” Em: ANTUNES, M. A. M. (org.) História da Psicologia no Brasil: primeiros ensaios. Rio de Janeiro: EdUERJ: Conselho Federal de Psicologia, 2004.

CAMPOS \& CURY, Fontes Primárias: Saberes em movimento. Rev. Fac. Educ., Jan 1997, vol.23, no.1-2.

CAUTELLA, W. "Plantão Psicológico em Hospital Psiquiátrico” Em: MORATO, H.T.P. Aconselhamento Psicológico Centrado na Pessoa: novos desafios. São Paulo: Casa do Psicólogo, 1999.

CHAUÍ, M.S. Cultura e democracia: o discurso competente e outras falas. São Paulo: Moderna, 1984.

CHELMERS, A. A fabricação da ciência SP editora UNESP, 1994.

COUCH, A. 1997 O processo analítico São Paulo: Escuta, 1997.

CRITELLI, D. M. Analítica do sentido: uma aproximação e interpretação do real de orientação fenomenológica São Paulo: EDUC : Brasiliense, 1996.

EISENLOHR, M.G.V. Formação de alunos em psicologia :uma possibilidade para educadores. Dissertação (Mestrado) São Paulo: IPUSP, 1997

FIGUEIREDO, L.C A invenção do psicológico: quatro séculos de subjetivação (14001900) São Paulo: EDUC; Petrópolis: Vozes, 1992.

Revistando as psicologias: da epistemologia à ética das práticas e discursos psicológicos São Paulo: EDUC; Petrópolis: Vozes, 1995a. Modos de subjetivação no Brasil São Paulo: EDUC; Petrópolis: Vozes, 1995b. 
FIGUEIREDO, L.C. e JÚNIOR, N. C. Ética e técnica em psicanálise São Paulo: Escuta, 2000.

FILHO, M.B.L. “A Psicologia no Brasil nos últimos 25 anos” Em: ANTUNES, M. A. M. (org.) História da Psicologia no Brasil: primeiros ensaios. Rio de Janeiro: EdUERJ: Conselho Federal de Psicologia, 2004.

FOUCAULT, M. Resumo dos cursos do Collége de France (1970-1982) Rio de Janeiro: Jorge Zahar Ed., 1997.

A ordem do discurso. São Paulo: Edições Loyola, 2000, 6a . ed.

FRANCO, M. A. R. S. A Pedagogia como ciência da educação: entre práxis e epistemologia. Tese (Doutorado) São Paulo: FEUSP, 2001.

FREIRE, P. Por uma pedagogia da pergunta Rio de Janeiro-RJ : Paz e Terra, 1985. Pedagogia do Oprimido Rio De Janeiro : Paz E Terra, 1985. Medo e ousadia: o cotidiano do professor. Rio De Janeiro : Paz E Terra, 1989.

GENDLIN, E. Experiecing and the creation of meaning: a philosophical and psychological aproach New York: Free Press, 1976

GODOY, M. Supervisão no curso de psicologia: análise de um caso clínico. Dissertação (Doutorado) São Paulo: IPUSP, 1985

GOFFMAN, E. Manicômios, prisões e conventos [Trad] Dante Moreira Leite ; [Rev] Antenor Celestino de Souza. São Paulo : Perspectiva, 1996.

HEIDEGGER, M. Ser e tempo Petrópolis:Vozes, 1997

LYOTARD, J. F. O pós-moderno Rio de Janeiro: José Olympio, 1988 2ª ed. 
MANCEBO, D. “Formação em Psicologia: gênese e primeiros desenvolvimentos” Em: JACÓ-VILELA, A. M., JABUR, F., RODRIGUE, H. B. C. (orgs.) Histórias da Psicologia no Brasil Rio de Janeiro: UERJ, NAPE, 1999.

MERLEAU-PONTY, M. Merleau-Ponty na Sorbonne: resumo dos cursos Psicossociologia e Filosofia Campinas, SP: Papirus, 1990.

MOFFAT, A. Terapia de crise. São Paulo: Cortez, 1987. 3ed. Psicoterapia do Oprimido São Paulo: Cortez, 1985.

MORATO, H.T.P. Eu - Supervisão: em cena uma ação buscando Significado Sentido. Tese (Doutorado) São Paulo: IPUSP, 1989.

"Aconselhamento Psicológico: uma passagem para a transdisciplinaridade” Em: Aconselhamento Psicológico Centrado na Pessoa: novos desafios São Paulo: Casa do Psicólogo, 1999.

MORATO, H. T. P., AUN, H. A Atenção psicológica como metodologia interventiva e institucional em unidade de internação da FEBEM Relatório Técnico-Científico, São Paulo, IPUSP 2002

MORATO, H. T. P., AUN, H. A. e cols. Atenção psicológica como metodologia interventiva e institucional em unidade de internação da FEBEM Em: Anais do I Congresso Brasileiro Psicologia: Ciência e Profissão., 2002, São Paulo. Fórum de Entidades Nacionais da Psicologia Brasileira., 2002

“Aprendizagem significativa e experiência: um grupo de encontro em instituição acadêmica" Em: "Aconselhamento Psicológico Centrado na Pessoa: novos desafios" São Paulo: Casa do Psicólogo, 1999.

NUNES, A. P. Sem título Trabalho apresentado à disciplina Aconselhamento Psicológico centrado no Cliente, São Paulo: IPUSP, 2001. 
NUNES, B. Heidegger e a poesia Em: Natureza Humana: Revista internacional de filosofia e práticas psicoterápicas São Paulo: Educ, 1999 vol. I, n.1 (1999) p. 103-128.

PATTERSON, C. H. "Theories of Counseling and Psychotherapy" New York: Harper \& Row, 1973.

PATTO, M.H.S. “A constituição da psicologia científica” In: . "Psicologia e Ideologia” São Paulo: T.A. Queiroz, 1984. “Fracasso escolar: a natureza do discurso oficial” In: A produção do fracasso escolar. São Paulo, T. A. Queiroz, 1997.

PRICE, D. S. O homem e a ciência En: A ciência desde a babilônia Ed. Itatiaia São Paulo Edusp, 1976 trad. Leônidas Hegenberg e Octamy S. da Mota Godoy.

PRISZCULNIK, L. “Clínica médica e clínica psicanalítica” São Paulo: Revista Psiquê vol. 2, p. 111-1211995

PROCÓPIO, D. A crise como pissibilidade de crescimento pessoal: uma leitura heideggeriana. Lorena, SP: Sitiliano, 2000.

ROGERS, C. "Tornar-se pessoa" Lisboa : Moraes, 1967. . "Um jeito de ser" São Paulo: EPU, 1983. . "Liberdade para aprender em nossa década" Porto Alegre: Artes Médicas, 1985.

ROMERO, M. L. C. Transmissão-difusão da psicanálise : considerações a partir do delineamento de sua presença nos cursos de psicologia da região do triângulo mineiro Brasil central São Paulo: IPUSP, 1993 Tese (Doutorado)

RUDOLFER, M. História da Psicologia São Paulo IPUSP, 1936

SANTANA, A. F. Atenção Psicológica em Rede Pública de Saúde: interrogando sentidos sobre a vida em sofrimento Dissertação (mestrado) Recife: UNICAP,2001. 
SAVIANNI, D. 1997Escola e democracia São Paulo: Cortez, 1997.

SERRES, M. Filosofia mestiça Rio de Janeiro : Nova Fronteira, 1993. . Hermes - uma filosofia das ciências Rio de Janeiro : Graal, 1990.

SCHIMIDT, M. L. S A experiência de psicólogas na comunicação de massa Tese (Doutorado) São Paulo: IPUSP, 1990.

SZYMANSKI, H. Práticas Educativas Familiares: a família como foco de atenção psicoeducacional. Campinas: Estudos de Psicologia, v.21, p.05 - 16, 2004.

VAISBERG, T. M. J. A. Ser e fazer: interpretação e intervenção na clínica winnicottiana. Psicol. USP, 2003, vol.14, no.1, p.95-128.

WINNICOTT, D. W. Consultas terapêuticas em psiquiatria infantil Rio de Janeiro : Imago, 1984. 


\section{Bibliografia:}

ARAÚJO, J. N. G. e Carreteiro, T. C. (orgs) “Cenários sociais e abordagem clínica” São Paulo: Escuta; Belo Horizonte, Fumec, 2001.

emas em Psicologia: entrevista e grupos” São Paulo: Martins Fontes, 1998.

JOVCHELOVICH, S. “Representações sociais e esfera pública: a construção simbólica dos espaços públicos no Brasil” Petrópolis, RJ: Vozes, 2000.

OROFIAMMA, R. “Comment le sens vient au récit” In: OROFIAMMA, R.; DOMINICÉ, P. e LAINÉ, A. “Les histories de vie: théories et paratiques” Paris: Education Permanente, 2001.

SOUZA, MPR “A Queixa escolar e a formação do Psicólogo”. Tese (Doutorado) São Paulo: IPUSP, 1992. 